Operations Office.

\title{
LIGHT WATER REACTOR FUEL REPROCESSING: MASTER DISSOLUTION STUDIES OF VOLOXIDIZED AND NONVOLOXIDIZED FUEL
}

D. R. JOHNSON AND J. A. STONE

Approved by

J. D. Spencer, Research Manager

Fuel Cycle Technology Division

Published April 1980

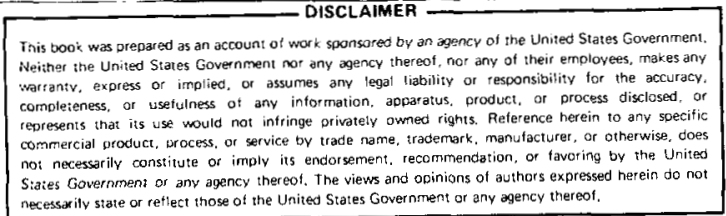

APPLIED TECHNOLOGY

Issued by E. I. du Pont de Nemours \& Co.

Savannah River Laboratory

Aiken, SC 29808

PREPARED For THE U. S. DEPARTMENT OF ENERGY UNDER CONTRACT DE-ACO9-76SR00001

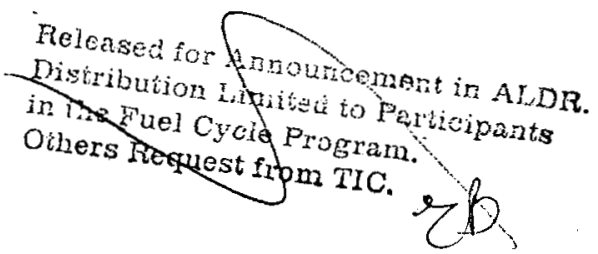




\section{DISCLAIMER}

This report was prepared as an account of work sponsored by an agency of the United States Government. Neither the United States Government nor any agency Thereof, nor any of their employees, makes any warranty, express or implied, or assumes any legal liability or responsibility for the accuracy, completeness, or usefulness of any information, apparatus, product, or process disclosed, or represents that its use would not infringe privately owned rights. Reference herein to any specific commercial product, process, or service by trade name, trademark, manufacturer, or otherwise does not necessarily constitute or imply its endorsement, recommendation, or favoring by the United States Government or any agency thereof. The views and opinions of authors expressed herein do not necessarily state or reflect those of the United States Government or any agency thereof. 


\section{DISCLAIMER}

Portions of this document may be illegible in electronic image products. Images are produced from the best available original document. 
Small-scale tests with irradiated Zircaloy-clad fuels from Robinson, Oconee, Saxton, and Point Beach reactors with burnups from about 200 to $28,000 \mathrm{MWD} / \mathrm{MTHM}$ have been made to determine the dissolution behavior of both voloxidized $\left(\mathrm{U}_{3} \mathrm{O}_{8}\right)$ and nonvoloxidized $\left(\mathrm{UO}_{2}\right)$ fuel. No significant technical problems were encountered in batch-dissolving of either form. Dissolution rates were wel1controlled in all tests. Significant characteristics of $\mathrm{U}_{3} \mathrm{O}_{8}$ dissolution that differed from $\mathrm{UO}_{2}$ dissolution included: (1) reduced tritium and ruthenium ( $106 \mathrm{Ru})$ concentrations in product solutions, (2) increased insoluble noble metal fission product residue (about $2.2 \mathrm{X}$ greater), and (3) increased insoluble plutonium in the fission product residue. The insoluble plutonium is easily leached from the residue by $10 \mathrm{M} \mathrm{HNO}_{3}$. The weight of the fission product residue collected from both $\mathrm{U}_{3} \mathrm{O}_{8}$ and $\mathrm{UO}_{2}$ fuels increased approximately linearly with fuel burnup. A major fraction $(>83 \%)$ of the $85 \mathrm{Kr}$ was evolved from $\mathrm{U}_{3} \mathrm{O}_{8}$ fuel during dissolution rather than voloxidation. The ${ }^{85} \mathrm{Kr}$ evolution rate was an appropriate monitor of fuel dissolution rate. Virtually all of the ${ }^{129}$ I was evolved by air sparging of the dissolver solution during dissolution. 
This report contains information developed from three programs :

Alternate Fuel Cycle Technologies (AFCT)

Thorium Fuel Cycle Technologies (TFCT)

International Spent Fuel Storage (ISFS)

These programs were structured into a single overall program, the Converter Fuel Cycle Technology (CFCT) program, to optimize disposition of spent fuel from light water reactors (LWR's).

The AFCT program was directed primarily at reprocessing and recycling uranium and plutonium by processes that reduce the risk of nuclear weapons proliferation.

Processing steps include head end treatment of spent fuel, dissolution of fuel, recovery and purification of uranium and plutonium by a solvent extraction process, and treatment of offgases from various parts of the processing system.

The AFCT program was formerly the LWR fuel recycle program. A preliminary design integration study of a spent fuel reprocessing complex for a U/Pu cycle based on separate $U$ and $P u$ streams was completed in FY-1978, and a coprocessing flowsheet design was completed in FY-1979.

The TFCT program, an extension of the AFCT program, assessed aqueous reprocessing of thorium reactor fuel. The primary criterion for evaluating thorium fuel cycles was the extent to which the potential for international proliferation of nuclear materials was reduced. Although processing steps for the TFCT program were the same as those for the AFCT program, different techniques were required.

On October 1978 the CFCT program became the CFP, or Convertor Fuel Processing, program. The CFP program ended on September 30, 1979 . 
Purpose of Dissolution Tests 9

Fuel Description 11

H. B. Robinson-2 Reactor Fuel

Oconee-1 Reactor Fuel

Saxton Reactor Fuel

Batch Dissolution Process 14

Dissolution Rate 17

Characterization of Dissolver Solution 25

Characterization of Insoluble Residue 36

Off-Gas Characterization 46

$\mathrm{NO}_{\mathbf{x}}$ Evolution

Tritium

Carbon-14

Krypton -85

Iodine-129

Semivolatile Fission Products

Experimental 50

Dissolution Equipment

Glass Apparatus

Voloxidizer-Dissolver

Off-Gas System

Dissolution Procedures

Feed Clarification

Insoluble Residue Characterization

Analytical Techniques

References 60

Appendix A: Fuel Shearing 63

Appendix B: Static Bed Voloxidation: Procedures and Results 66

Appendix C: Dissolution Tests with Point Beach Reactor Fuel 72 


\section{LIST OF TABLES}

1 Measured Isotopic Compositions for Irradiated Fuels 13

2 Dissolution Conditions for Robinson-2 Fuel 18

3 Dissolver Solution Parameters for Robinson-2 Fuel 26

4 Dissolution Conditions for Oconee-1 Fuel 27

5 Dissolver Solution Parameters for Oconee-1 Fuel 28

6 Dissolution Conditions for Saxton Fuel 29

7 Dissolver Solution Parameters for Saxton Fuel 30

8 Gamma-Emitting Fission Products in Dissolved Robinson-2 Fuel Solutions 30

9 Gamma-Emitting Fission Products in Dissolved Oconee-1 Fuel Solutions 31

10 Gamma-Emitting Fission Products in Dissolved Saxton Fuel Solutions 31

11 Distribution of Volatile Radionuclides from Processing of Irradiated Robinson-2 Fue1 33

12 Distribution of Volatile Radionuclides from Processing of Irradiated Oconee-1 Fuel 34

13 Distribution of Volatile Radionuclides from Processing of Irradiated Saxton Fuel 35

$14 \mathrm{Pu}(\mathrm{IV})$ Concentration in Dissolver Solution at Various . Time Intervals During and Following Dissolution 38

15 Insoluble Residue Collected from Irradiated Fuel Dissolution Tests 38

16 Analysis of Insoluble Residues by Spark-Source Mass Spectrometry 39

17 Characterization of Insoluble Residue by Acid Leaching 41 
18 Analysis of Insoluble Residue Collected from Previously-Centrifuged Dissolver Solutions, by Spark-Source Mass Spectrometry 45

19 Gamma-Emitting Fission Products in Dissolver and Off-Gas Scrubber Solutions 49

20 Analyses for Gaseous Radioactive Species Collected in Off-Gas System 59

1B Voloxidation Test of Unirradiated Clad-UO 2 Fuel 68

2B Weights of Voloxidized Fuel Pieces from Oconee-1

Reactor During Static Bed Voloxidation Test 70

3B Weight of Uranium Oxide During Static-Bed Voloxidation of Oconee-1 Fuel 71

1C Measured Isotopic Compositions for Point Beach Fuel 73

2C Dissolution Conditions for Point Beach Fuel 74

3C Dissolver Solution Parameters for Point Beach Fuel 77

4C Gamma-Emitting Fission Products in Dissolved Point Beach Fuel Solution 78

5C Distribution of Volatile Radionuclides from Processing of Irradiated Point Beach Fuel 80

6C Insoluble Residue Collected from Point Beach Fuel Dissolution Tests 81

7C Acid Leaching of Insoluble Residue Collected from Point Beach Fuel 82 
1 Head-End Process Operations for Reprocessing Spent LWR Fuels 10

2 Batch Dissolution Flowsheet for Spent LWR Fuel 15

3 Dissolution Rates of Irradiated $\mathrm{UO}_{2}$ and $\mathrm{U}_{3} \mathrm{O}_{8}$ Fuels in Acid Dissolvent by Batch Processing

4 Dissolution Rates of Irradiated and Unirradiated $\mathrm{U}_{3} \mathrm{O}_{8}$ Powders Produced from Voloxidation 20

5 Dissolution Rates of Irradiated and Unirradiated $\mathrm{UO}_{2}$ Fue1 20

6 Comparison of $85 \mathrm{Kr}$ Evolution Rate and Uranium Dissolution Rate for Nonvoloxidized Oconee-1 Fuel 21

7 Comparison of $85 \mathrm{Kr}$ Evolution Rate and Uranium Dissolution Rate for Voloxidized Saxton Fuel 22

8 Fuel Dissolution Rates for Various Initial Acid Concentrations 23

9 Insoluble Residue Collected after Fuel Dissolution vs. Fuel Burnup 37

10 Plutonium Solubility in Voloxidized Fuel as a Function of Final Dissolver Acid Concentration 42

11 Glass Apparatus for Dissolution Tests in High Level Shielded Cells 51

12 Metal Voloxidation/Dissolution Equipment for Dissolution Tests in High Level Shielded Cells 52

13 Dissolver Off-Gas System 53

14 Clarification of Dissolver Solution by Centrifugation

1A Single-Pin Shear for Cutting LWR Fuel Rods 64

2A Sheared Fuel Rod from H. B. Robinson-2 Reactor 65

IB Voloxidation of $\mathrm{Clad} \mathrm{UO}_{2}$ Fuel 67

1C Dissolution Rates of Irradiated Point Beach Fue1 76 
LIGHT WATER REACTOR FUEL REPROCESSING:

DISSOLUTION STUDIES OF VOLOXIDIZED AND

NONVOLOXIDIZED FUEL

PURPOSE OF DISSOLUTION TESTS

The Alternate Fuel Cycle Technologies (AFCT) program was designed to provide data needed to evaluate selected alternative systems for the disposition of spent nuclear fuel. These data were obtained through laboratory research and development programs at the Savannah River Laboratory (SRL) and other Department of Energy laboratories and programs in industrial groups and universities.

As part of this effort, SRL studied shear-leach processing of 1 ight water reactor ( $L W R$ ) fuels. A proposed reference flowsheet for head-end steps in the shear-leach process is shown in Figure 1. A voloxidation step is included to evolve tritium for recovery as tritiated water from an off-gas stream. This step minimizes tritium releases to the environment.

During voloxidation, the sheared fuel pieces are roasted in oxygen or air at about $500^{\circ} \mathrm{C}$ to convert $\mathrm{UO}_{2}$ to $\mathrm{U}_{3} \mathrm{O}_{8}$. This process oxidizes tritium to HTO which is expected to be released quantitatively to the off-gas system. The oxidation reaction also expands the fuel, dislodges it from the Zircaloy cladding, and produces a powdered $\mathrm{U}_{3} \mathrm{O}_{8}$ product with a fine particle size $(<44 \mathrm{~m})$ and a high surface area. Little information had been reported for dissolution behavior of irradiated voloxidized fuel. The high surface area of the $\mathrm{U}_{3} \mathrm{O}_{8}$ product could cause rapid fuel dissolution in $\mathrm{HNO}_{3}$, and rapid generation of nitrogen oxides $\left(\mathrm{NO}_{\mathrm{x}}\right)$. These rapid reactions could cause operating problems in the dissolver and/or the associated off-gas system. Therefore, small-scale tests with irradiated fuels (about 200-g batches) were made in high-level shielded facilities to determine dissolution behavior of voloxidized fuels and to provide design information for a reprocessing plant incorporating voloxidation as a head-end operation.

To identify any technical problems associated with reprocessing of voloxidized fuels, dissolution of voloxidized fuels was compared to dissolution of identical nonvoloxidized fuels. These tests have also provided information on the distribution of some volatile fission products between the voloxidation and the dissolver off-gas streams. 


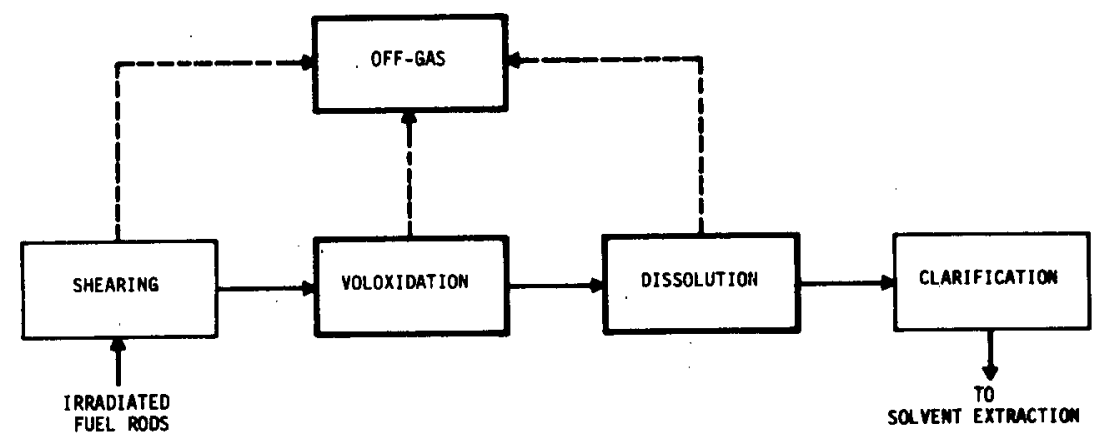

FIGURE 1. Head-End Process Operations for Reprocessing Spent LWR Fuels 
FUEL DESCRIPTION

All fuels were originally Zircaloy-clad $\mathrm{UO}_{2}$ fuel pellets fabricated to $94 \%$ theoretical density. Specific fuel histories are:

\section{H. B. Robinson-2 Reactor Fuel}

This fuel held an initial $235_{U}$ enrichment of 2.55 percent and a reported peak burnup of about $31,500 \mathrm{MWD} / \mathrm{MTHM}_{\mathrm{O}}$ * $^{*}$ Depending on the time of the tests, the fuel had cooled from 2- to 3.5 years (discharged May 1974). Tests 1, 2, 3, 5, and 8 were conducted with unclad $\mathrm{UO}_{2}$ fuel fragments taken from Rod A-1 of Assembly B-05. This fuel was mechanically separated from the Zircaloy-4 cladding at Battelle Memorial Institute. Test 4 was conducted with clad fuel from Rod 0-14 of Assembly B-05. This fuel piece was from the end of the fuel rod and was expected to have a lower and more-variable burnup ( 6800 to $27,000 \mathrm{MWD} / \mathrm{MTHM}_{\mathrm{O}}$ ).

\section{Oconee-1 Reactor Fuel}

Fuel Rod No. 47108 was irradiated in Assembly 1 Al6 during Cycle 1 operation and was discharged in October 1974 (2- to 3 -yr cooling period). Initial enrichment was $2 \% 235^{U}$. Peak fuel burnup was reported as $13,900 \mathrm{MWD} / \mathrm{MTHM}_{\mathrm{O}}$. Total fuel rod length was $150 \mathrm{in}$. with a fuel column length of 143.1 in. The rod was cut into 16.0 to $17.5-i n$. segments at the Oak Ridge National Laboratory prior to shipment to SRL.

\section{Saxton Reactor Fuel}

The fuel rods were irradiated in the Core III loading and were discharged in May 1972 (about a 5-yr cooling period). 1 Initial enrichment was $12.5 \% 235 \mathrm{U}$. Peak fuel burnup was variable in the four rods tested, based on available fuel exposure history data.2-5

\footnotetext{
* MTHM $_{O}$ is the initial heavy metal (i.e., $U$ and $\mathrm{Pu}$ ) content of the fuel in metric tons charged to the reactor.
} 
The burnups reported above for the three fuel types have been revised based on isotopic uranium and plutonium distributions and plutonium concentrations determined from dissolved fue 1 solutions (Table 1). The measured isotopic distributions and plutonium concentrations were compared with expected distributions and concentrations as a function of fuel exposure calculated by the GLASS Code.6,7 The calculated burnups determined from this approach are:

- Fuel fragments from rod A-1 of Robinson-2, about 28,000 MWD/MTHM ;

- Rod 0-14 from Robinson-2, about 19,000 MWD/MTHM

- Oconee-1 rod segments, 10,000 to $12,000 \mathrm{MWD} / \mathrm{MTHM}_{\mathrm{O}}$;

- Saxton fuel rods used in Tests 9, 11, 13, and 14, 3000 to 4500 MWD/MTHM ;

- Saxton fuel rod used in Test 16, about $200 \mathrm{MWD} / \mathrm{MTHM}_{\mathrm{O}}$; and

- Saxton fuel rod used in Test 18, about $8000 \mathrm{MWD} / \mathrm{MTHM}_{\mathrm{O}}$. 
TABLE 1

Measured Isotopic Compositions for Irradiated Fuelsa

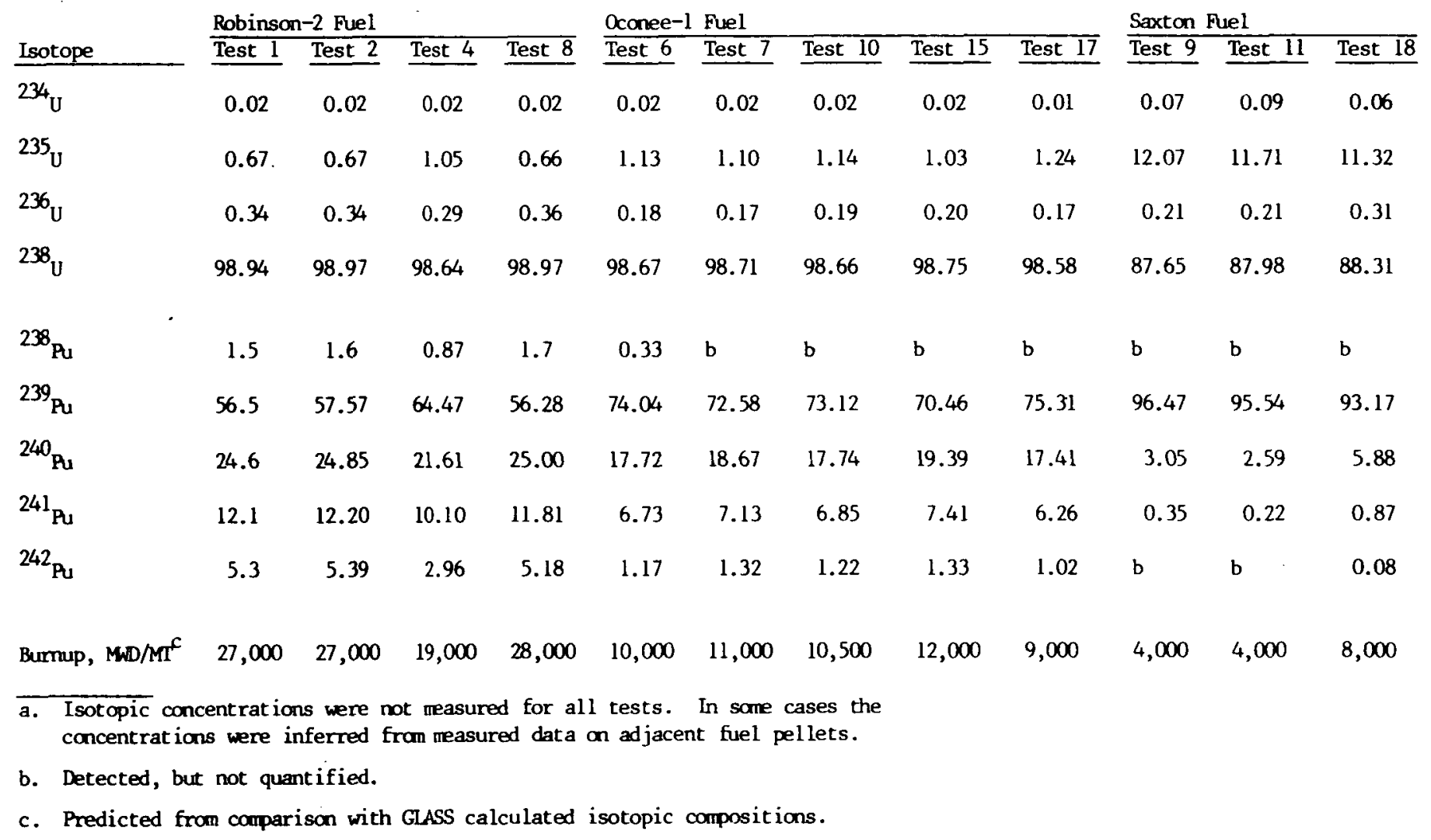




\section{BATCH DISSOLUTION PROCESS}

A batch dissolution process for these tests was developed from dissolution experience at the Savannah River Plant (SRP) and at Nuclear Fuel Services 8,9 from proposed plans for the Barnwell Nuclear Fuel Plant, 10 and from other published information. 11-14

The dissolution process (Figure 2) is designed to provide control of the dissolution rate and the corresponding $\mathrm{NO}_{\mathrm{x}}$ evolution rate of the fine-powdered $\mathrm{U}_{3} \mathrm{O}_{8}$ product. The recommended flowsheet provides dissolution control by:

1) limiting the concentration of the initial batch acid charge $\left(<3 \mathrm{M} \mathrm{HNO}_{3}\right)$,

2) limiting the initial solution temperature $\left(<50^{\circ} \mathrm{C}\right)$,

3) metering concentrated acid (10M $\left.\mathrm{HNO}_{3}\right)$ slowly to promote dissolution, and

4) increasing solution temperature slowly to $90^{\circ} \mathrm{C}$ only after the fuel is largely dissolved.

The recommended dissolution process is conducted by batchcharging sheared fuel to the dissolver containing the desired volume of 1 to $3 \mathrm{M} \mathrm{HNO}_{3}$ at ambient temperature. The $10 \mathrm{M} \mathrm{HNO}_{3}$ charge is metered immediately into the dissolver over a period of 1 to 2 hours. The solution is maintained below $50^{\circ} \mathrm{C}$ (by cooling, if necessary) until a substantial portion of the fuel has dissolved ( $>50 \%)$. This will usually occur within 1.5 to 2 hours after the initial acid charge and could be monitored by specific gravity measurements. Then, the solution is heated slowly to $90^{\circ} \mathrm{C}$ and maintained at that temperature for 2 hours with reflux. During the dissolution cycle, an air sparge may be provided to remove iodine from the dissolver solution. The final dissolver solution is transferred to a separate tank for accountability measurements and for any head-end clarification treatment. 


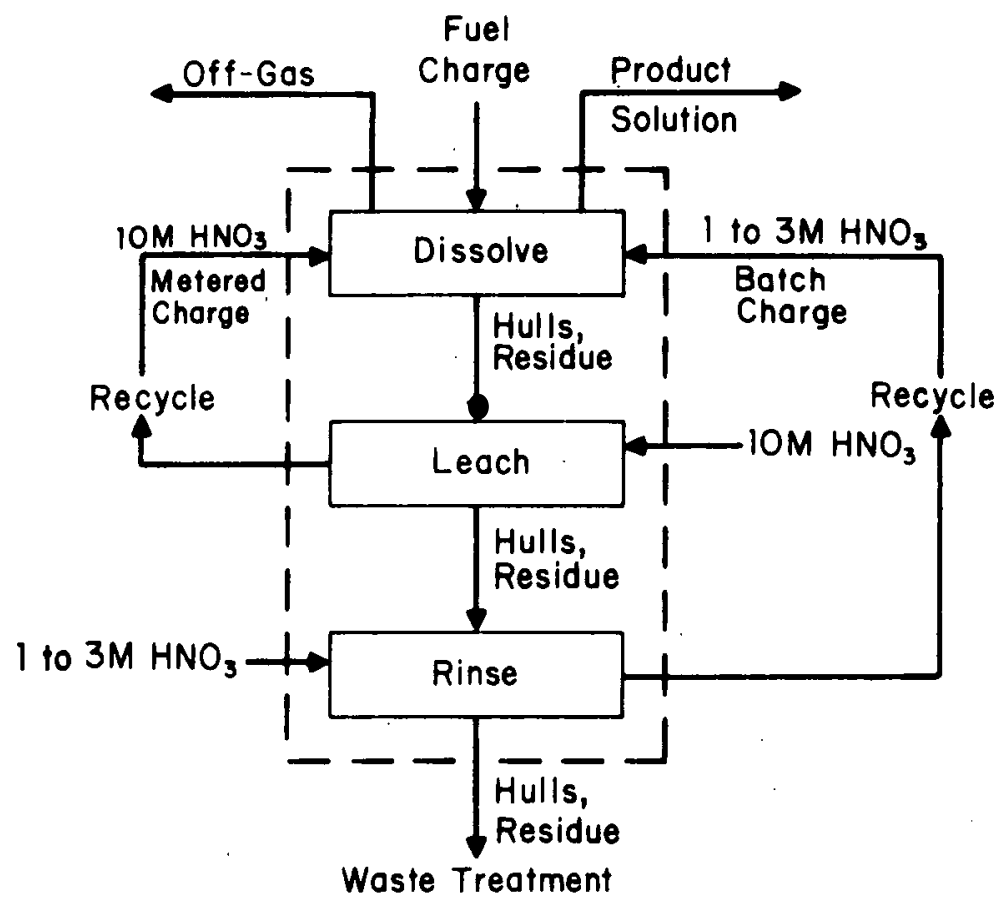

FIGURE 2. Batch Dissolution Flowsheet for Spent LWR Fuel 
In a plant process, the spent hulls and any residue would be leached at $90^{\circ} \mathrm{C}$ for several hours with fresh $10 \mathrm{M} \mathrm{HNO}_{3}$ to recover undissolved actinides after the dissolution cycle is completed. The leach solution could be recycled for use in the next dissolution cycle. The spent hulls would be rinsed with 1 to $3 \mathrm{M} \mathrm{HNO}_{3}$. The recovered acid rinse could be recycled for use as the initial acid charge in the next dissolution cycle. The spent hulls then would be handled as solid waste. This process is intended to provide for economical use of acid dissolvents and to ensure complete actinide recovery from spent $\mathrm{UO}_{2}$ fuels.

Dissolution rate must be controlled in order to reduce the off-gassing rate to a level which does not overload the designed off-gas system. The assumed dissolution reactions for calculating off-gas flow are: 11

Reaction 1

$$
\mathrm{UO}_{2}+4 \mathrm{HNO}_{3} \rightarrow \mathrm{UO}_{2}\left(\mathrm{NO}_{3}\right)_{2}+2 \mathrm{NO}_{2}+2 \mathrm{H}_{2} \mathrm{O} \quad\left(>8 \mathrm{M} \mathrm{HNO}_{3}\right)
$$

Reaction 2

$$
\mathrm{UO}_{2}+2.7 \mathrm{HNO}_{3} \rightarrow-\mathrm{UO}_{2}\left(\mathrm{NO}_{3}\right)_{2}+0.7 \mathrm{NO}+1.3 \mathrm{H}_{2} \mathrm{O} \quad(<8 \mathrm{M} \mathrm{HNO} 3)
$$

\section{Reaction 3}

$$
\mathrm{U}_{3} \mathrm{O}_{8}+8 \mathrm{HNO}_{3} \rightarrow-3 \mathrm{UO}_{2}\left(\mathrm{NO}_{3}\right)_{2}+2 \mathrm{NO}_{2}+4 \mathrm{H}_{2} \mathrm{O}
$$

Based on initial dissolution studies on Robinson-2 fuel and the expected solution acid concentrations ( 1 to $6 \mathrm{M} \mathrm{HNO}_{3}$ ), $\mathrm{UO}_{2}$ fuel dissolution is better represented by Reaction 2 than Reaction 1. The off-gas rate of Reaction 2 is about one-third that of Reaction 1 and is the basis for calculating any off-gas rates from $\mathrm{UO}_{2}$ fuels. The off-gas rate for Reaction 2 is equivalent to that expected for $\mathrm{U}_{3} \mathrm{O}_{8}$ dissolution. 


\section{DISSOLUTION RATE}

In tests with Robinson, Oconee, and Saxton fuels, clad $\mathrm{UO}_{2}$ fuel and powdered $\mathrm{U}_{3} \mathrm{O}_{8}$ fuel from voloxidation were dissolved at rapid, but controlled, rates by the described batch dissolution process. Fuels in all of these laboratory-scale tests were dissolved within three hours of initiating acid charges to the fuel. Dissolution conditions for all tests are reported in Tables 2, 4, and 6. No differences in fuel dissolution rates as a function of fuel exposure were noted for either the $\mathrm{UO}_{2}$ or $\mathrm{U}_{3} \mathrm{O}_{8}$ fuel forms.

Clad $\mathrm{UO}_{2}$ and powdered $\mathrm{U}_{3} \mathrm{O}_{8}$ fuel dissolved at about the same rates (Figure 3 ). Much faster $\mathrm{U}_{3} \mathrm{O}_{8}$ dissolution had been expected because the $\mathrm{U}_{3} \mathrm{O}_{8}$ has a very high surface area. The results demonstrate excellent control of the $\mathrm{U}_{3} \mathrm{O}_{8}$ dissolution reaction for conditions of the batch dissolution process.

Tests with unirradiated voloxidized $\mathrm{UO}_{2}$ fuel pellets demonstrated that unirradiated $\mathrm{U}_{3} \mathrm{O}_{8}$ dissolved at nearly the same rate as irradiated $\mathrm{U}_{3} \mathrm{O}_{8}$ (Figure 4). The somewhat higher dissolution rate for irradiated $\mathrm{U}_{3} \mathrm{O}_{8}$ is attributed to sampling problems (discussed in Experimental Section).

Irradiated $\mathrm{UO}_{2}$ pellets (as fragments) dissolve much more rapidly than unirradiated $\mathrm{UO}_{2}$ pellets (Figure 5) because the fuel surface area exposed to the acid dissolvent is increased significantly by fracture during irradiation. A single-batch charge of $6 \mathrm{M} \mathrm{HNO}_{3}$ was used for the tests plotted in Figure 5, resulting in more rapid initial dissolution rates than observed for the proposed batch dissolution process.

For those tests where $85 \mathrm{Kr}$ evolution was measured, the $85_{\mathrm{Kr}}$ evolution rate was found to be a useful monitor of dissolution rate (Figure 6 for nonvoloxidized fuel, Figure 7 for voloxidized fuel). The dissolution rate measured from uranium analysis of samples taken during the dissolution actually are somewhat higher than the ${ }^{85} \mathrm{Kr}$ evolution rate. However, this is explained by the continued dissolution of trace amounts of oxide powder in sampled solutions (discussed in Experimental Section).

The initial fuel dissolution rate at ambient temperature $\left(<30^{\circ} \mathrm{C}\right)$ depended on the acid concentration of the initial batch charge. For initial acid concentrations of $3 \mathrm{M}, 1 \mathrm{M}$, and $0.5 \mathrm{M}$ $\mathrm{HNO}_{3}$, about 60 to $70 \%, 35$ to $50 \%$, and 25 to $40 \%$, respectively, of the total fuel charge was dissolved in 90 minutes (Figure 8). Lowering the initial acid concentration reduces the acid 
TABLE 2

\section{Dissolution Conditions for Robinson-2 Fuel}

Test 1 Test 2 Test 3 Test 4 Test 5 Test 8 d

Total Charge, $\mathrm{g}^{\mathrm{a}}$

$162.8344 .5 \quad 180.0$

$202.3 \quad 205.6 \quad 166.9$

Oxide Fuel Charge, $g$

$162.8 \quad 344.5 \quad 180.0$

$169.5 \quad 205.6 \quad 166.9$

Fuel Form

$\mathrm{w}_{2} \quad \mathrm{w}_{2} \quad \mathrm{w}_{2}$

$\mathrm{WO}_{2} \quad \mathrm{U}_{3} \mathrm{O}_{8} \quad \mathrm{U}_{3} \mathrm{O}_{8}$

Rod Number

Initial Acid Charge, $M$

A-1 A-1

6.45

A-1

A-1

0-14 A-1 A-1

Initial Charge Volume, $\mathrm{mL}$

450

$10 \mathrm{HNO}_{3}$ Volume, mL

- $\quad-\quad 270$

$\begin{array}{lll}2.97 & 3.0 & 1.0\end{array}$

$170 \quad 210 \quad 169$

$10 \mathrm{MNO}_{3}$ Meter Time, min

- $\quad-\quad 75$

$220 \quad 270 \quad 220$

$10 \mathrm{HNO}_{3}$ Metering, Start At, $\mathrm{hr}^{\mathrm{b}}$

$67 \quad 62 \quad 59$

Heating Initiated $\mathrm{At}, \mathrm{hr}^{\mathrm{b}}$

0.2

$\begin{array}{llllll}4.2 & 2.75 & 4.2 & 4.5 & 3.5 & 3.7\end{array}$

Total Dissolving Time, $\mathrm{hr}^{\mathrm{b}}$

2.0

2.0

1.0

$1.4 \quad 1.0$

2.2

a. Includes Zircaloy-4 cladding weight, if weight differs from oxide charge.

b. Times relative to initial acid charge.

c. Heating varied, so that not continuous (see Experimental Section).

d. Test 8 in metal voloxidation/dissolution equipment (all others in glass equipment). 


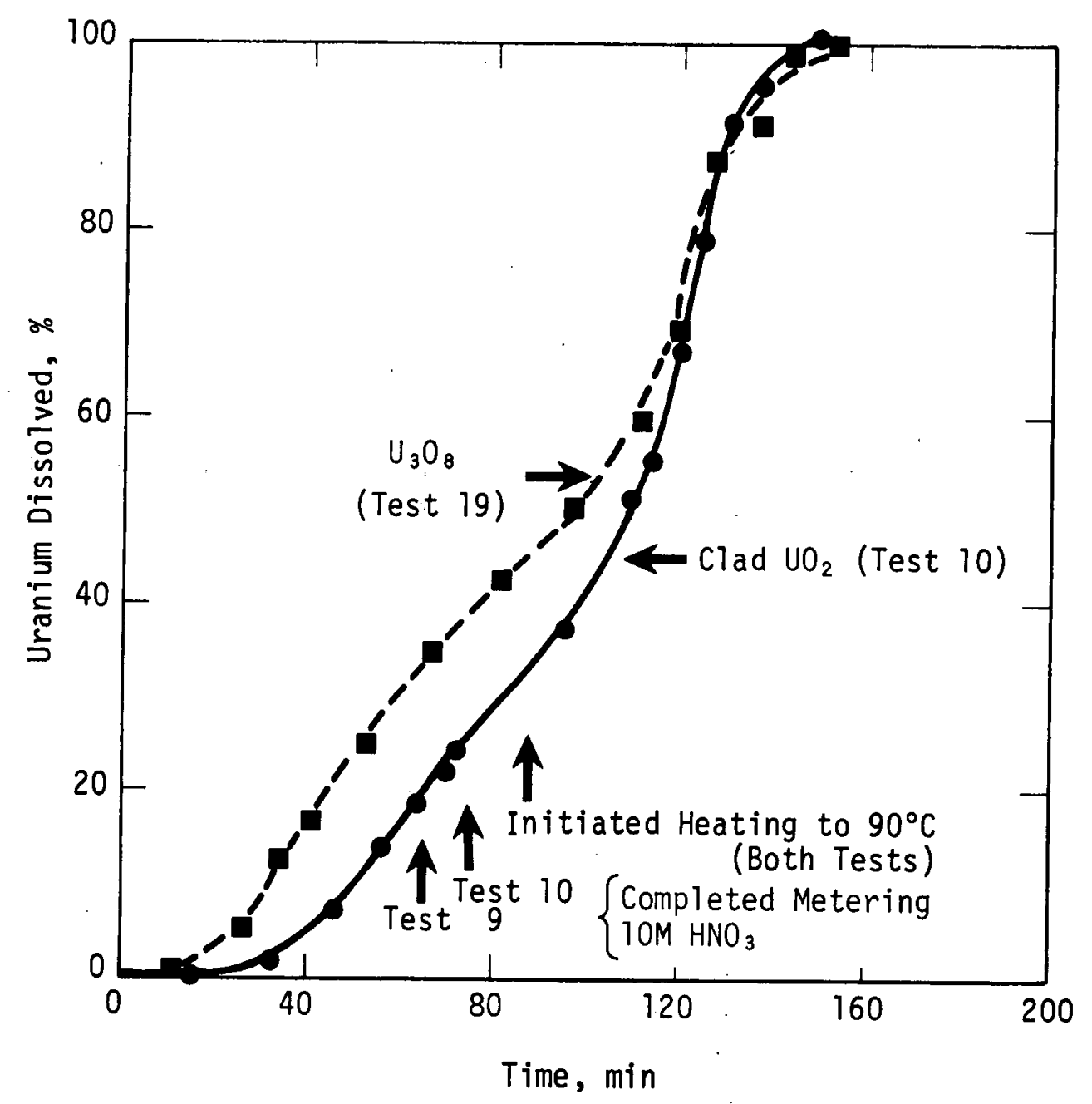

FIGURE 3. Dissolution Rates of Irradiated $\mathrm{UO}_{2}$ and $\mathrm{U}_{3} \mathrm{O}_{8}$ Fuels in Acid Dissolvent by Batch Processing 


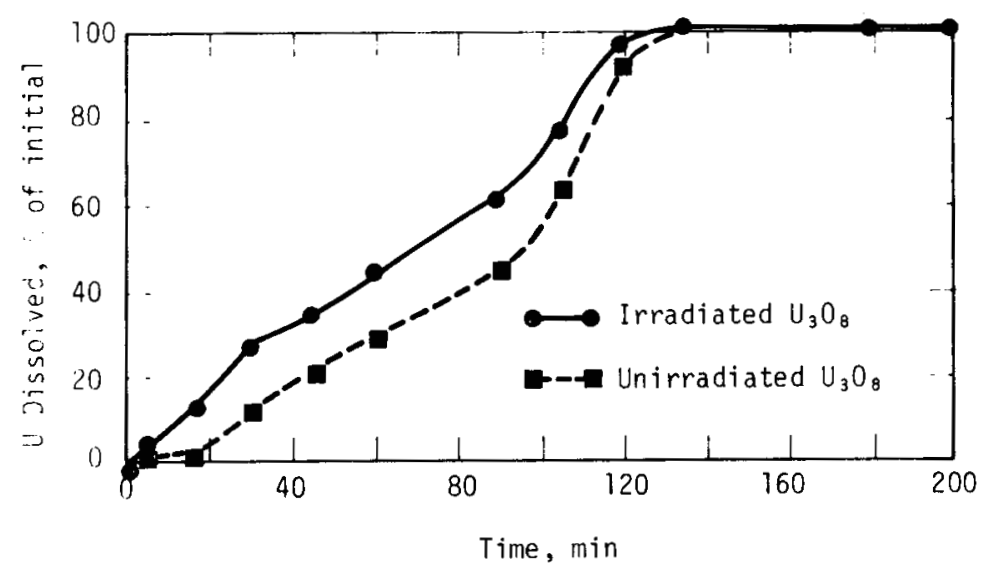

FIGURE 4. Dissolution Rates of Irradiated and Unirradiated $\mathrm{U}_{3} \mathrm{O}_{8}$ Powders Produced from Voloxidation

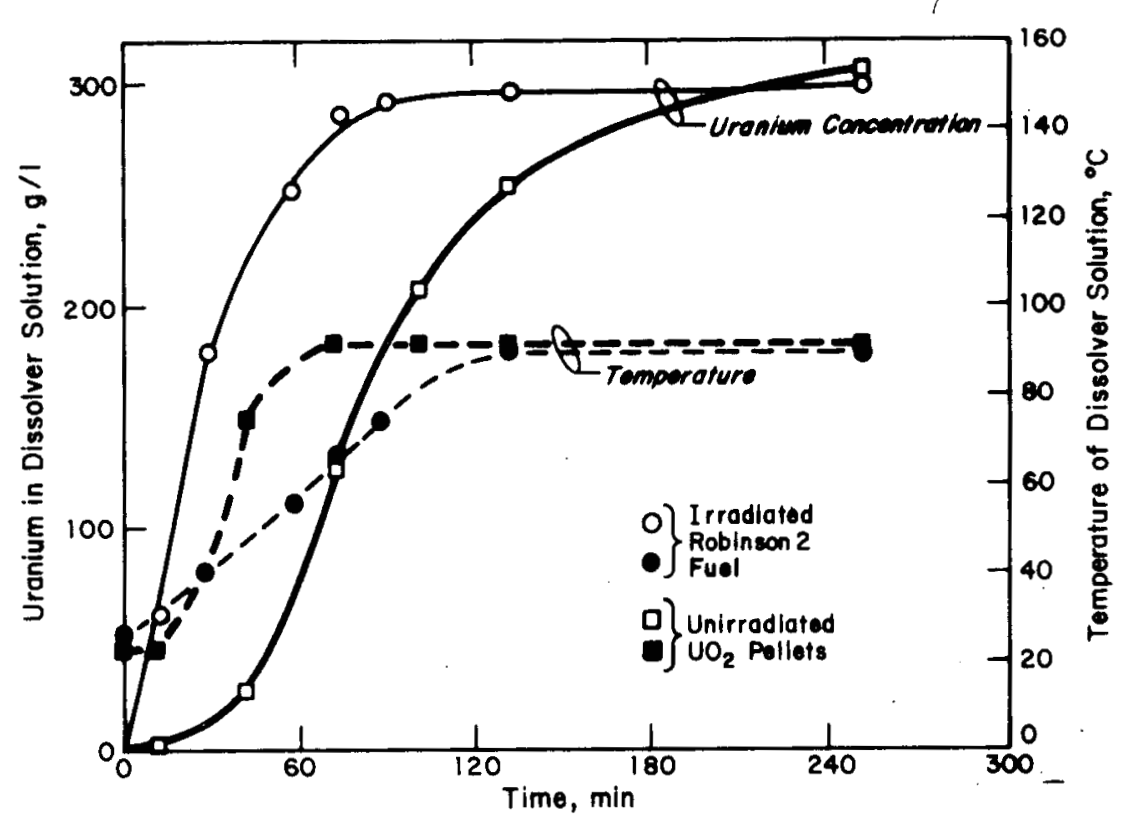

FIGURE 5. Dissolution Rates of Irradiated and Unirradiated $\mathrm{UO}_{2}$ Fuel 


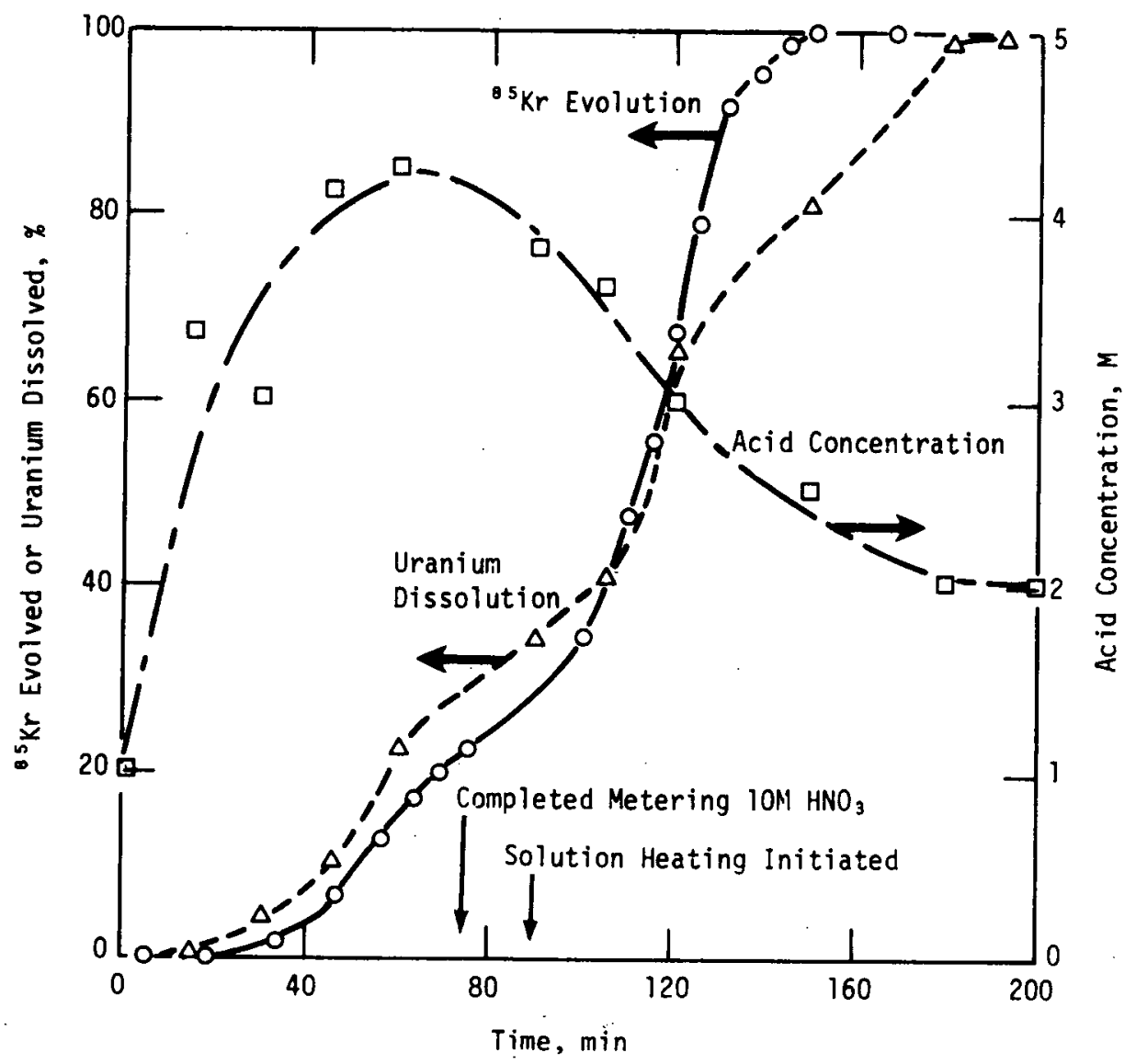

FIGURE 6. Comparison of $85_{\mathrm{Kr}}$ Evolution Rate and Uranium Dissolution Rate for Nonvoloxidized Oconee-1 Fuel 


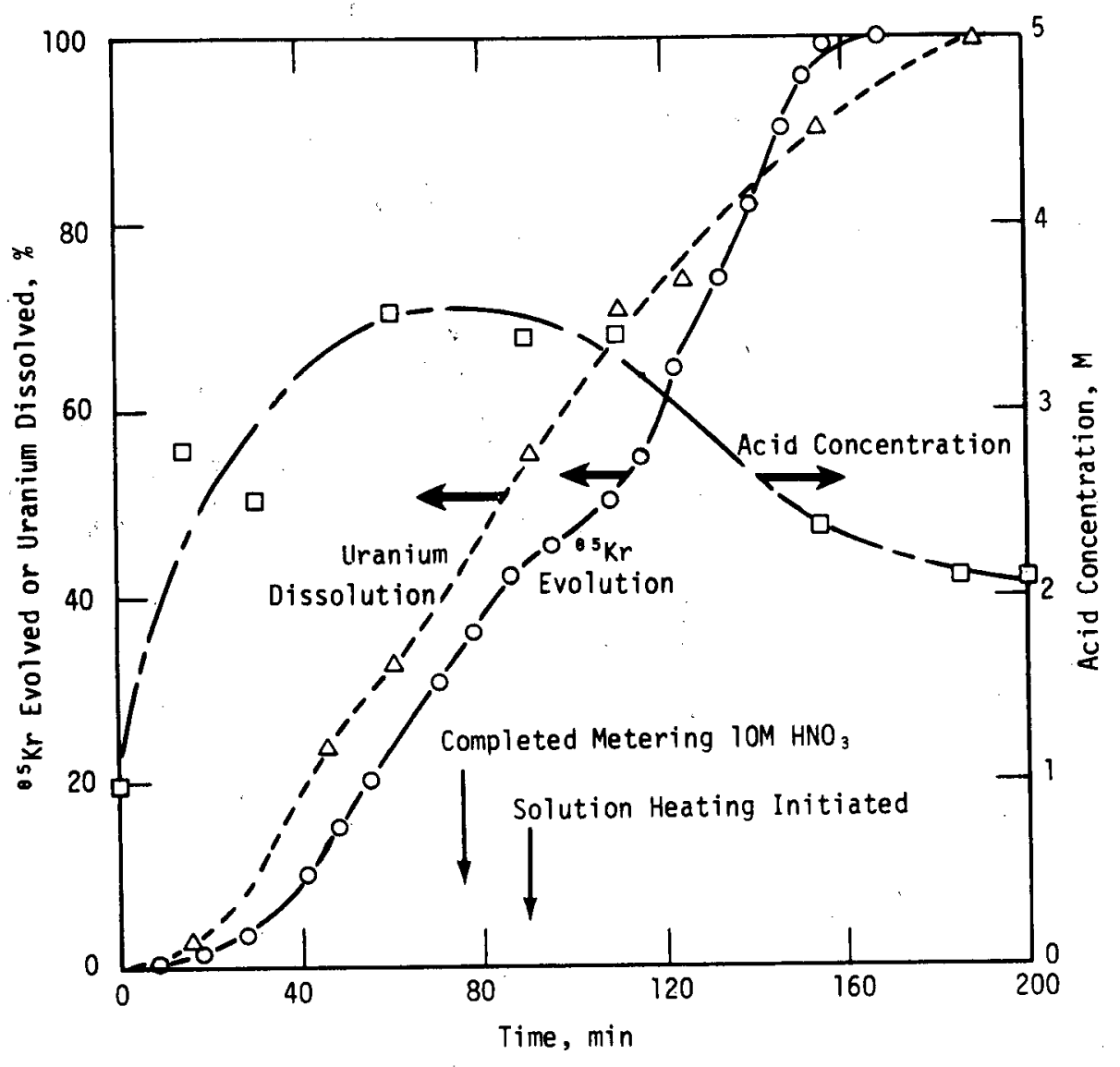

FIGURE 7. Comparison of $85 \mathrm{Kr}$ Evolution Rate and Oranium Dissolution Rate for Voloxidized Saxton Fuel 


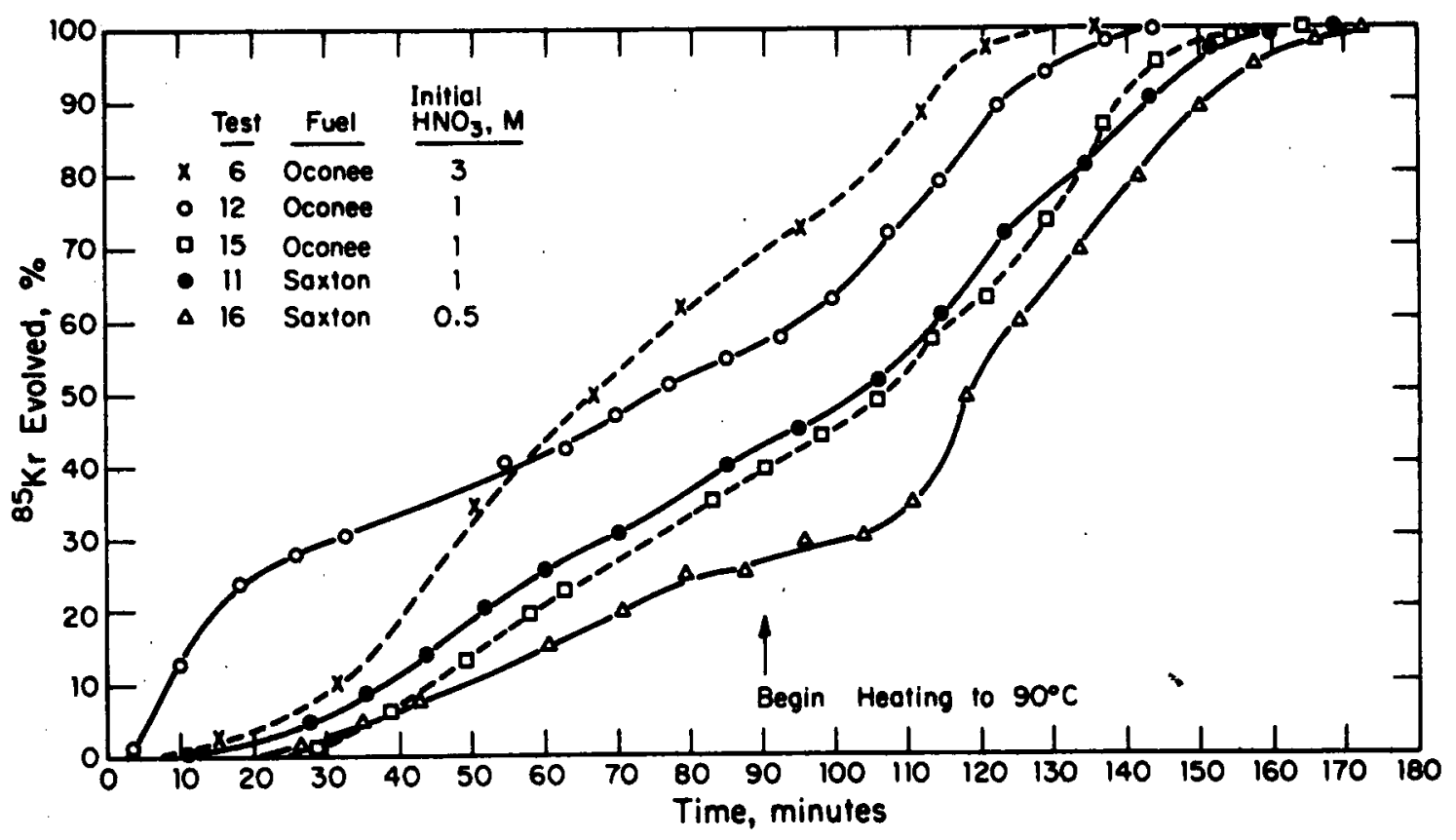

FIGURE 8. Puel Dissolution Rates for Varions Inltial Acid Concentrations 
concentration profile in the dissolver during metering of $10 \mathrm{M} \mathrm{HNO}_{3}$ thus reducing the dissolution rate. The maximum measured acid concentration in any test did not exceed $5.5 \mathrm{M} \mathrm{HNO}_{3}$, and was usually lower. Analysis of the acid profile indicated that the fuel dissolved at a rate somewhat slower than the $10 \mathrm{M} \mathrm{HNO}_{3}$ metering rate. Thus, the maximum acid concentration of the solution was achieved at the time that the metered acid addition was completed. Continued fuel dissolution then depleted the acid to the final expected concentration of 2 to $3 \mathrm{M} \mathrm{HNO}_{3}$. In some tests using an initial $3 \mathrm{M}^{\mathrm{HNO}_{3}}$ acid charge, variable acid reflux, caused by experimental conditions, resulted in unexpectedly high final solution acid concentrations (about $3.5 \mathrm{M} \mathrm{HNO}_{3}$ in Tests 5, 6, and 7). Such high acid concentrations cannot be diluted directly to an appropriate concentration for solvent extraction (about 2.5M $\mathrm{HNO}_{3}$ ) while maintaining desired uranium concentration $(285 \mathrm{~g} \mathrm{U} / \mathrm{L})$. Thus, $1 \mathrm{M} \mathrm{HNO}_{3}$ was utilized as an initial batch charge in subsequent tests to achieve final dissolver solutions of about $350 \mathrm{~g} \mathrm{U} / \mathrm{L}$ and $2 \mathrm{MNO}_{3}$, which could be diluted directly to solvent extraction fuel concentrations.

The importance of initial solution temperature control for voloxidized fuels was demonstrated during Test 12 when the solution temperature was raised to $60^{\circ} \mathrm{C}$ early in the dissolution (Figure 8 ). About $25 \%$ of the total fuel charge dissolved rapidly, within 20 minutes. When the temperature was reduced to ambient cell temperature $\left(<30^{\circ} \mathrm{C}\right)$, dissolution was as slow as in the other tests. Thus, to ensure controlled off-gas flows that will not overload off-gas equipment, temperature must be controlled precisely during batch dissolution of voloxidized fuel. Heating rates normally were contolled to $<3^{\circ} \mathrm{C} / \mathrm{min}$ in all tests to avoid rapid dissolution of the fuel.

During most tests, the $10 \mathrm{M} \mathrm{HNO}_{3}$ charge was metered immediately after the first batch of acid was added to the fuel. This procedure was adopted after a preliminary dissolution test with $\mathrm{U}_{3} \mathrm{O}_{8}$ powder formed by voloxidation of unirradiated $\mathrm{UO}_{2}$ fuel pellets showed that acid depletion of the dissolvent $\left(<0.1 \mathrm{M} \mathrm{HNO}_{3}\right)$ occurred within one hour of batch charging $3 \mathrm{M} \mathrm{HNO}_{3}$ at ambient cell temperature. This low acidity could result in the formation of an inextractable plutonium polymer during dissolution of irradiated fuel. For tests with $\mathrm{UO}_{2}$ fuel pellets (Tests 3 and 4 ), acid depletion was not quite as severe (about $1.0 \mathrm{M} \mathrm{HNO}_{3}$ from an initial batch charge of 2 to $3 \mathrm{M} \mathrm{HNO}_{3}$ ). Since tests have shown that the dissolution rate during metered addition of $10 \mathrm{M} \mathrm{HNO}_{3}$ to $\mathrm{UO}_{2}$ and $\mathrm{U}_{3} \mathrm{O}_{8}$ fuels is well-controlled, initiation of the metered acid charge immediately following the batch acid charge is justified to avoid acid depletion of the dissolvent. This also reduces total dissolution time without adding significantly to off-gas flow rate. 
Final dissolver solution analyses (Tables 3, 5, and 7) were consistent with complete dissolution of uranium fuel. Measured plutonium concentrations in Robinson, Oconee, and Saxton fuels were found to be $0.91,0.55$, and $0.11 \mathrm{wt} \%$, respectively, of the total uranium charged to the dissolver. These concentrations are in the range expected for the fuel exposures as determined by the GLASScode calculations. 7 Sampled solutions indicated that the uranium dissolution rate was not faster than the plutonium dissolution rate.

In the tests, the actinide and fission product concentration in the first $1 \mathrm{M} \mathrm{HNO}_{3}$ rinse of the dissolver vessel generally indicated a dissolver solution heel of 1 to $2 \%$ of total volume. In the second rinse, actinide and fission product concentrations were $<0.05 \%$ of that in the dissolver. The rinses contained only traces of solid residue, indicating complete fuel dissolution. The $10 \mathrm{M} \mathrm{HNO}_{3}$ leach of the rinsed cladding from these tests contained $<0.05 \%$ of the uranium and plutonium concentrations in the dissolver, which further demonstrated that only a very slight amount of fuel remained undissolved.

Measured gamma-emitting fission-product concentrations in the dissolver solutions (Tables 8,9 , and 10) show that the soluble ${ }_{106} \mathrm{Ru}$ concentrations from voloxidized fuels $\left(\mathrm{U}_{3} \mathrm{O}_{8}\right)$ were significantly lower than the soluble $106_{\mathrm{Ru}}$ concentrations from similar $\mathrm{UO}_{2}$ fuels. Both fuel solution types contained equivalent concentrations of ${ }^{137} \mathrm{Cs}$ and ${ }^{144} \mathrm{Ce}$, which were completely soluble in the acid dissolvents. The reduced solubility of $106_{\mathrm{Ru}}$ after voloxidation was accounted for by an increased insoluble residue rather than by any ruthenium volatilization during voloxidation (discussed in Residue Characterization Section). Reduced ruthenium concentration in the solvent extraction feed solution is beneficial because a lower decontamination factor for ruthenium will be required and solvent damage by radiolysis will be reduced.

The fuel charge for Test 12 was incompletely oxidized $\left(\mathrm{U}_{4} \mathrm{O} g\right.$ ) based on voloxidation 15 and $\mathrm{X}$-ray data. The $106 \mathrm{Ru}$ concentration in the dissolved fuel solution from this test was intermediate between the concentrations measured for voloxidized and unvoloxidized fuel (Table 9). Thus, the extent to which ruthenium and other fission product solubilities are reduced appears to depend on the extent of oxidation of the fuel. 
TABLE 3

Dissolver Solution for Robinson-2 Fuel

$\underline{\text { Test } 1}$ Test 2 Test 3 Test 4 Test 5 Test 8

Solution Volume, mL

$\begin{array}{llllll}460 & 980 & 485 & 400 & 490 & 385 \\ 3.16 & 2.4 & 3.23 & 2.63 & 3.55 & 2.95\end{array}$

Uranium, $g / \mathrm{L}$

$\begin{array}{llllll}308 & 295 & 320 & 344 & 345 & 355\end{array}$

Plutonium, g/L

$2.56^{\mathrm{c}} \quad 3.08^{\mathrm{d}} \quad 3.02^{\mathrm{c}}$

$2.82^{\mathrm{c}}$

$3.14^{c}$

$3.10^{c}$

Density, $\mathrm{g} / \mathrm{mL}$, at $22^{\circ} \mathrm{C}$

MP $\quad \mathrm{NM}$

Gross Alpha, dis/(min) $(\mathrm{g} \mathrm{U})^{\mathrm{a}}$

$1.54 E 10$

$1.56 \mathrm{E} 10$

NM

NM

NM

1.585

${ }^{237} \mathrm{NP}, \mathrm{g} / \mathrm{L}^{\mathrm{a}}$

0.127

NM

$1.51 \mathrm{E} 10$

$8.14 E 09$

$1.42 \mathrm{E} 10$

$1.40 \mathrm{E} 10$

${ }^{241} \mathrm{Am}, \mathrm{g} / \mathrm{L}^{\mathrm{a}}$

0.055

0.049

0.099

$\mathbf{M}$

M $\quad M$

${ }^{242} \mathrm{Cm}, \mathrm{mg} / \mathrm{L}^{\mathrm{a}}$

0.13

0.12

0.047

0.050

0.069

0.091

${ }^{244} \mathrm{om}, \mathrm{mg} / \mathrm{L}^{\mathrm{a}}$

6.7

6.6

0.11

0.05

0.09

0.04

Decay Time at Analysis, $\mathrm{yr}^{\mathrm{b}}$

2.28

2.37

7.6

2.3

7.6

8.3

a. Uncorrected for alpha decay (all concentrations at analysis date).

b. Fuel discharge date: May 6, 1974.

c. Based on alpha count of extracted plutonium samples.

d. Based on gross alpha count.

e. Not measured. 
TABLE 4

Dissolution Conditions for Oconee-1 Fuel

\begin{tabular}{|c|c|c|c|c|c|c|c|}
\hline & Test $6^{\mathrm{a}}$ & Test $7^{\mathrm{a}}$ & Test 10 & Test 12 & Test 15 & Test 17 & Test 19 \\
\hline Total Charge, $g^{b}$ & 224.0 & 237.4 & 224.0 & 253.0 & 206.1 & 141.9 & 265.2 \\
\hline Oxide Fuel Charge, ${ }^{g}$ & 185.0 & 194.0 & 185.5 & 199.6 & 206.1 & 141.9 & 206.4 \\
\hline Fuel Form & $w_{2}$ & $\mathrm{U}_{3} \mathrm{O}_{8}$ & $\mathrm{w}_{2}$ & $\mathrm{U}_{4} \mathrm{O}_{9}^{\mathrm{f}}$ & $\mathrm{U}_{3} \mathrm{O}_{8}$ & $\mathrm{U}_{3} \mathrm{O}_{8}$ & $\mathrm{U}_{3} \mathrm{O}_{8}$ \\
\hline Fuel Section Charged ${ }^{c}$ & 83.5 & 49.0 & 66.5 & $g$ & 32.5 & 100.0 & 16.0 \\
\hline Initial Acid Charge, $M$ & 3.0 & 3.0 & 1.0 & 1.0 & 0.5 & 0.5 & 1.0 \\
\hline Initial Charge Volume, mL & 192 & 196 & 196 & 207 & 209 & 145 & 210 \\
\hline $10 \mathrm{M} \mathrm{HNO}_{3}$ Volume, mL & 250 & 253 & 253 & 268 & 219 & $150^{i}$ & 270 \\
\hline $10 \mathrm{M} \mathrm{NN}_{3}$ Meter Time, $\min ^{\mathrm{d}}$ & 69 & 61 & 74 & 74 & 60 & 61 & 66 \\
\hline Heat ing Inititated at, $h r^{e}$ & 1.5 & 1.5 & 1.5 & $1.5^{\mathrm{h}}$ & 1.5 & 1.5 & 1.5 \\
\hline Total Dissolving Time, hr ${ }^{e}$ & 4.0 & 3.5 & 4.0 & 4.0 & 4.5 & 4.5 & 4.0 \\
\hline Total Time at $90^{\circ} \mathrm{C}$, hr & 1.8 & 1.4 & 1.5 & 1.9 & 2.2 & 2.2 & 2.0 \\
\hline
\end{tabular}

a. Test 6 and 7 in glass equipment; other tests in metal voloxidation/dissolution equipment.

b. Includes Zircaloy-4 cladding weight, if different from oxide charge.

c. Position of lower point of rod section used for test, measured in inches from bottam of rod as placed in the reactor; each rod section 16.5 to 17.5 inches long.

d. All $1 \mathrm{OM}^{\mathrm{NO}} 3$ additions initiated immediately after initial acid charge.

e. Times relative to initial acid charge.

f. Voloxidation and x-ray data indicated incompletely oxidized fuel.

g. Composite of fuel pieces not used in Tests 6,7 , and 10.

h. Variable heat ing history (see Experimental Section).

i. Metered $8.5 \mathrm{M} \mathrm{HNO}_{3}$. 
TABLE 5

Dissolver Solution for Oconee-1 Fuel

Test 6 Test 7 Test 10 Test 12 Test 15 Test 17 Test 19

Solution Volume, mi

$\begin{array}{lllllll}430 & 430 & 415 & 480 & 430 & 300 & 490 \\ 3.45 & 3.80 & 2.05 & 2.10 & 1.60 & 0.80 & 2.40 \\ 380 & 348 & 380 & 355 & 400 & 405 & 355 \\ 2.01 & 1.90 & 2.10 & 2.01 & 2.33 & 1.97 & 1.99 \\ \mathrm{MM}^{\mathrm{C}} & 1.589 & 1.580 & 1.561 & 1.598 & 1.578 & 1.557 \\ 2.6 \mathrm{E} 09 & 2.8 \mathrm{E} 09 & 2.4 \mathrm{E} 09 & 2.4 \mathrm{E} 09 & 2.9 \mathrm{E} 09 & 2.0 \mathrm{E} 09 & 2.7 \mathrm{E} 09 \\ \mathrm{NM} & 0.032 & 0.040 & \mathrm{NM} & \mathrm{NM} & \mathrm{NM} & \mathrm{NM} \\ 0.027 & 0.026 & 0.024 & 0.021 & 0.038 & 0.018 & 0.031 \\ 0.015 & 0.012 & 0.008 & 0.006 & 0.006 & 0.003 & 0.004 \\ 0.22 & 0.22 & 0.26 & 0.19 & 0.39 & 0.13 & 0.26 \\ 2.49 & 2.67 & 2.86 & 2.98 & 3.24 & 3.35 & 3.50\end{array}$

a. Uncorrected for alpha decay (all concentrations at analysis date).

b. Fuel discharge date: October 15, 1974.

c. Not measured. 
TABLE 6

Dissolution Conditions for Saxton Fuela

Test 9 Test 11 Test 13 Test 14 Test 16 Test 18

Total Charge, $\mathrm{g}^{\mathrm{b}}$

$\begin{array}{llllll}258.6 & 266.9 & 245.5 & 258.8 & 269.8 & 192.7\end{array}$

Oxide Fuel Charge, $g$

$\begin{array}{llllll}212.3 & 211.9 & 193.0 & 208.2 & 213.2 & 192.7\end{array}$

Fuel Form

$\begin{array}{llllll}\mathrm{U}_{3} \mathrm{O}_{8} & \mathrm{U}_{3} \mathrm{O}_{8} & \mathrm{U}_{3} \mathrm{O}_{8} & \mathrm{U}_{3} \mathrm{O}_{8} & \mathrm{U}_{3} \mathrm{O}_{8} & \mathrm{U}_{3} \mathrm{O}_{8}^{\mathrm{g}}\end{array}$

Fuel Rod Charged ${ }^{c}$

B $\quad$ C

B C

C D

A

Initial Acid Charge, M

$1.0 \quad 1.0$

0.5

0.5

0.5

1.0

Initial Charge Volume, mL

$216 \quad 216$

196

211

217

196

$10 \mathrm{HNO}_{3}$ Volume, mL

279

279

205

221

$226^{\mathrm{f}}$

253

$10 \mathrm{M} \mathrm{HNO}_{3}$ Meter Time, $\min ^{\mathrm{d}}$

$77 \quad 71$

47

68

65

72

Heating Initiated At, $\mathrm{hr}^{\mathrm{e}}$

1.5

1.5

1.5

1.5

1.5

1.5

Total Dissolving Time, hre

4.5

4.3

4.5

4.5

4.4

4.0

Total Time at $90^{\circ} \mathrm{C}, \mathrm{hr}$

$2.0 \quad 2.2$

2.2

2.2

2.4

1.8

a. All tests in metal voloxidation/dissolution equipment.

b. Includes Zircaloy-4 cladding weight, if different from oxide charge.

c. Arbitrary designation to identify tests using similar fuel rods.

d. All IOM $\mathrm{HNO}_{3}$ charges initiated immediately after initial acid charge.

e. Times relative to initial acid charge.

f. Metered 8.5 $\mathrm{NNO}_{3}$.

g. Voloxidiation data indicated incouplete axidation of fuel. 
TABLE 7

Dissolver Solution for Saxton Fuel

Test 9 Test 11 Test 13 Test 14 Test 16 Test 18

Solution Volume, $\mathrm{mL}$

$\begin{array}{llllll}465 & 485 & 410 & 430 & 450 & 460 \\ 2.12 & 2.20 & 1.30 & 1.40 & 0.80 & 1.80\end{array}$

Uranium, $g / \mathrm{L}$

Plutonium, g/L

$\begin{array}{llllll}375 & 370 & 405 & 400 & 400 & 350\end{array}$

Density, $\mathrm{g} / \mathrm{mL}$, at $22^{\circ} \mathrm{C}$

0.40

0.34

0.44

0.38

0.02

0.60

Density, $\mathrm{g} / \mathrm{mL}$, at $22^{\circ} \mathrm{C}$

$1.577 \quad 1.571$

$1.611 \mathrm{NM}^{\mathrm{d}}$

$1.578 \quad 1.535$

Gross Alpha, dis $/(\min )(\mathrm{g} \mathrm{U})^{\mathrm{a}, \mathrm{b}}$

2. $1 \mathrm{EO} 8$

$1.6 \mathrm{EO} 8$

2.0EO8

1.6EO8

$2.5 \mathrm{EO} 7$

3.7EO8

Decay Time at Analysis, $\mathrm{yr}^{\mathrm{c}}$

5.29

5.45

5.57

5.63

5.75

5.90

a. Uncorrected for alpha decay.

b. Low fuel exposure history and long cooling time reduced concentration of ${ }^{237} \mathrm{~Np}$, ${ }^{241} \mathrm{Am},{ }^{242} \mathrm{Cm}$, and ${ }^{244} \mathrm{Cm}$ below precisely measurable levels.

c. Fuel discharge date: May 1, 1972.

d. Not measured.

TABLE 8

Gamma-Emitting Fission Products in Dissolved Robinson-2 Fuel Solutions

Activity, dis/(min) (g U) a,b

Not Voloxidized

Test 1 Test 2 Test 3 Test 4 $\frac{\text { Test } 5 \text { Test } 8}{2}$

106

$6.14 \mathrm{E} 11 \quad 4.23 \mathrm{E} 11 \quad 4.33 \mathrm{E} 11 \quad 4.18 \mathrm{E} 11 \quad 1.03 \mathrm{E} 11 \quad 1.60 \mathrm{E} 11$

$\begin{array}{lllllll}137 \mathrm{Cs} \quad 1.73 \mathrm{E} 11 & 1.81 \mathrm{E} 11 & 1.62 \mathrm{E} 11 & 1.23 \mathrm{E} 11 & 1.83 \mathrm{E} 11 & 2.22 \mathrm{E} 11\end{array}$

${ }^{144} \mathrm{Ce} \quad 1.76 \mathrm{E} 12 \quad 1.71 \mathrm{E} 12 \quad 1.44 \mathrm{E} 12 \quad 1.34 \mathrm{E} 12 \quad 1.75 \mathrm{E} 12 \quad 1.84 \mathrm{E} 12$

a. All activities at reactor discharge, corrected for decay, (see Table 3 for decay time).

b. ${ }^{106} \mathrm{Ru}(\mathrm{Rh}),{ }^{137} \mathrm{Cs}$, and ${ }^{144} \mathrm{Ce}$ were the only gamma-emitting nuclides in the solutions which could be measured with good precision. Other nuclides (such as $95 \mathrm{Zr}$ ) were present in such low concentrations that precise detection in the presence of the reported nuclides was impossible.

c. Lower burnup fuel from rod 0-14. 
TABLE 9

Gamma-Emitting Fission Products in Dissolved Oconee-1 Fuel Solutions

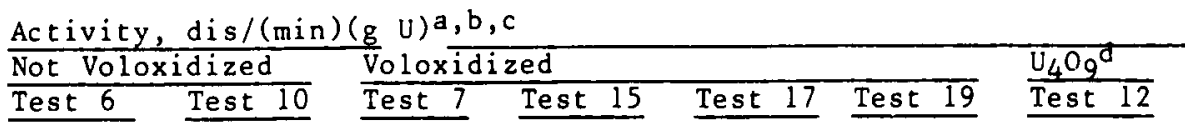

${ }^{106} \mathrm{Ru} \quad 2.67 \mathrm{E} 11 \quad 2.93 \mathrm{E} 11 \quad 1.1 \mathrm{E} 11 \quad 1.31 \mathrm{E} 11 \quad 1.2 \mathrm{E} 11 \quad 1.5 \mathrm{E} 11 \quad 1.89 \mathrm{E} 11$

$\begin{array}{llllllll}137 & \mathrm{Cs} \quad 8.0 \mathrm{E} 10 & 8.4 \mathrm{E} 10 & 8.9 \mathrm{E} 10 & 9.2 \mathrm{E} 10 & 7.0 \mathrm{E} 10 & 9.2 \mathrm{E} 10 & 7.5 \mathrm{E} 10\end{array}$

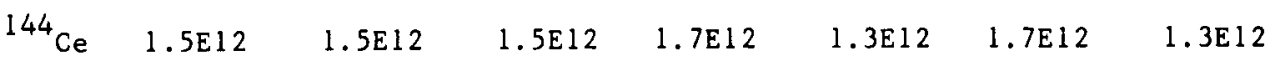

a. All activities at reactor discharge, corrected for decay, (see Table 5 for decay time).

b. $106 \mathrm{Ru}(\mathrm{Rh}), 137 \mathrm{Cs}$, and ${ }^{144} \mathrm{Ce}$ were the only gamma-emitting nuclides in the solutions which could be measured with good precision.

c. Variable burnup along the length of the rod from gross gamma scan profile agrees relatively well with distribution of $137 \mathrm{Cs}$ observed from each test.

d. Partially oxidized fuel from voloxidation.

TABLE 10

Gamma-Emitting Fission Products in Dissolved Saxton Fuel Solutions Activity, dis/(min)(g U) a,b,
Test 9 Test 11 Test 13 Test 14 Test 16 Test 18

$\begin{array}{lllllll}{ }^{106} \mathrm{Ru} & 3.1 \mathrm{E} 10 & 3.1 \mathrm{E} 10 & 4.1 \mathrm{E} 10 & 3.4 \mathrm{E} 10 & 5.0 \mathrm{E} 09 & 3.8 \mathrm{E} 10 \\ { }^{137} \mathrm{Cs} & 3.3 \mathrm{E} 10 & 2.8 \mathrm{E} 10 & 3.2 \mathrm{E} 10 & 3.0 \mathrm{E} 10 & 4.8 \mathrm{E} 08 & 6.9 \mathrm{E} 10 \\ { }^{144} \mathrm{Ce} & 4.6 \mathrm{E} 11 & 4.7 \mathrm{E} 11 & 5.4 \mathrm{E} 11 & 5.0 \mathrm{E} 11 & 5.3 \mathrm{E} 10 & 1.5 \mathrm{E} 12\end{array}$

a. All activities at reactor discharge, corrected for decay, (see Table 7 for decay times).

b. $106 \mathrm{Ru}(\mathrm{Rh}),{ }^{137} \mathrm{Cs}$, and ${ }^{144} \mathrm{Ce}$ were the only gamma-emitting nuclides in the solutions which could be measured with good precision.

c. All tests were made with voloxidized fuel. 
Tritium concentrations in the dissolver solutions from voloxidized fuels (Tables 11,12 , and 13) indicated that tritium was removed quantitatively from the fuel during voloxidation. Dissolver solutions from dissolution of nonvoloxidized fuels contained high tritium concentrations, as expected. The tritium concentration in the dissolver solution from incompletely oxidized fuel (Test 12) was significantly higher than observed in tests when the fuel was oxidized completely to $\mathrm{U}_{3} \mathrm{O}_{8}$. However, even with incomplete oxidation, about $87 \%$ of the tritium was released from the fuel by voloxidation.

Virtually all (>99.5\%) of the ${ }^{129}$ I was evolved from the dissolver solution by air sparging during dissolution, as determined by measured ${ }^{129}$ I concentrations in the caustic scrubber solutions of the glass equipment (Tables 11 and 12). Little difference in the evolution of ${ }^{129} \mathrm{I}$ was observed between voloxidized and nonvoloxidized fuels or between fuels of different exposure (Robinson vs. Oconee fuels). This result is favorable to solvent extraction processing, because organic solvent degradation by extractable iodine species will be minimized, particularly when processing short-cooled fuel.

The concentration of extractable $\mathrm{Pu}$ (IV) in the dissolver solution during and after dissolution was determined by preferential extraction of $\mathrm{Pu}$ (IV) into $0.5 \mathrm{M}$ thenoyltrifluoroacetone (TTA) in xylene. For analytical determination, the extracted plutonium was stripped from the organic phase with $8 \mathrm{M} \mathrm{HNO}_{3}$. Plutonium mass balance agreed well with total plutonium in the dissolver solution samples. The data for dissolution Tests 2 and 3 (Table 14) show that greater than $93 \%$ of the plutonium was in the tetravalent state during dissolution at near ambient temperatures (below $50^{\circ} \mathrm{C}$ ). After the dissolution at $90^{\circ} \mathrm{C}$ was completed, about $80 \%$ of the plutonium was $\mathrm{Pu}(\mathrm{IV})$; the remaining plutonium was assumed to be $\mathrm{Pu}(\mathrm{VI})$, which is less extractable. The Pu(IV) concentration remained unchanged for at least 24 hours after dissolution and increased to $85 \%$ and over $90 \%$ of the total plutonium after 48 and 144 hours, respectively. These results indicate that valence adjustment to $\mathrm{Pu}(\mathrm{IV})$ will be necessary to ensure quantitative extraction when solvent extraction is close-coupled with fuel dissolution.

The plutonium in the feed solution from Test 1 was not valence-adjusted prior to solvent extraction. However, the plutonium was extracted quantitatively in a mixer-settler test eight days after the dissolution, indicating that more than $90 \%$ of the plutonium was $\mathrm{Pu}(\mathrm{IV})$, in general agreement with the test results discussed above. 
TABLE 11

Distribution of Volatile Radionuclides from

Processing of Irradiated Robinson-2 Fuel

\section{$\underline{\text { Test } 1}$ Test 5 Test 8 Backgrounda}

Tritium, CI/MTU

$\begin{array}{lcccc}\text { Dissolver Solution } & 250.5 & 1.8 \times 10^{-3} & 4.1 \times 10^{-3} & 0.008 \\ \text { Voloxidation off-Gas b } & - & . N M^{d} & 133 & 1.2 \\ \text { DFc } & - & . M M & 3.3 \times 10^{4} & -\end{array}$

Carbon-14, C1/MTUe

$\begin{array}{lcccc}\text { Dissolver off-Gas } & N M & N M & 0.243 & 3 \times 10^{-5} \\ \text { Voloxidation of } f \text {-Gas } & - & \text { NM } & 0.066 & 5 \times 10^{-6} \\ \% \text { in Dissolver of } f-G a s & - & - & 78.6 & -\end{array}$

Krypton-85, C1/MTU

Dissolver of $f-G$ a

$\mathrm{NM}$

NI

1651

0.08

Voloxidation of $\mathrm{f}-\mathrm{Gas}$

- NY

137

0.07

$\%$ in Dissolver of $\mathrm{f}-\mathrm{Gas}$

$-$

92.3

Iodine-129, g/MTUf

$\begin{array}{llccc}\text { Dissolver Solution } & 0.001 & \text { NM } & 1.6 & 0.1 \\ \text { Dissolver of f-Gas } & 170.7 & \text { NM } & 58 & 0.009 \\ \text { Voloxidation of }- \text { Gas } & - & \text { NM } & 0.18 & 0.014 \\ \% \text { Remaining in Solution } & <0.001 & - & 2.6 & -\end{array}$

a. Determined in blank tests.

b. Tritium in dissolver off-gas was always at or below measured background $(0.015 \mathrm{Ci} / \mathrm{MTU})$.

c. Decontamination factor calculated as ratio of total tritiur. to tritium measured in dissolved tuel solution.

d. Not measured for given test.

e. Carbon-14 in dissolver solution was always at or below measured background $(0.04 \mathrm{Ci} / \mathrm{MTU})$.

f. Test 1 in glass equipment. Test 8 in thetal voloxider/dissulver equipment. 
TABLE 12

Distribution of Volatile Radionuclides from

Processing of Irradiated Oconee-1 Fuel $1^{a, b}$

$\underline{\text { Test } 6}$ Test 7 Test 10 Test $12^{\mathrm{C}}$ Test 15 Test 17 Test 19

Tritium, C1/MU

$\begin{array}{llllllll}\text { Dissolver Solution } & 7.2 & 0.63 & 35 & 0.91 & 0.002 & 0.013 & 0.035 \\ \text { Voloxidation off-Gas } & - & \text { NMd } & - & 6 & 16 & 27 & 7 \\ \text { DF } & - & - & - & 8 & 6560 & 2170 & 195\end{array}$

Carbon-14, CH/MIU

$\begin{array}{lccccccc}\text { Dissolver off-Gas } & \text { M } & \text { NM } & 0.081 & 0.104 & 0.124 & 0.104 & 0.141 \\ \text { Voloxidation off-Gas } & - & \text { NM } & - & 0.010 & 0.025 & 0.024 & 0.035 \\ \text { \% in Dissolver off-Cas } & - & - & 100 & 90.9 & 83.2 & 81.3 & 80.3\end{array}$

Kryptan-85, ci/MU

$\begin{array}{lccccccc}\text { Dissolver off-Gas } & \text { M } & \text { NM } & 1070 & 969 & 1087 & 1011 & 1058 \\ \text { Voloxidation Off-Gas } & - & \text { NM } & - & 41 & 123 & 77 & 115 \\ \text { \% in Dissolver Off-Gas } & - & - & 100 & 95.9 & 89.8 & 92.9 & 90.2\end{array}$

Iodine-129, g/MU

$\begin{array}{lccccccc}\text { Dissolver Solution } & 0.31 & 0.13 & 0.13 & <0.14 & <0.12 & 0.27 & \text { M } \\ \text { Dissolver Off-Cas } & 104 & 102 & \text { M } & \text { M } & 27 & 31 & 20 \\ \text { Voloxidation Off-Gas } & - & \mathrm{M} & - & \mathrm{M} & 0.03 & 0.76 & 1.7 \\ \text { \% Remaining in Solution } & 0.3 & 0.1 & - & - & <0.5 & 0.8 & -\end{array}$

a. See Table 11 for measured background levels determined from blank tests.

b. Tests 6 and 7 in glass equipment; all other tests in metal voloxidizer/dissolver equipment.

c. Partially oxidized fuel $\left(\mathrm{U}_{4} \mathrm{O} 9\right)$.

d. Not measured. 
TABLE 13

Distribution of Volatile Radionuclides from

Processing of Irradiated Saxton Fuela,b

$\underline{\text { Test } 9}$ Test 11 Test 13 Test 14 Test 16 Test $18 \mathrm{C}$

Tritium, ca/mav

$\begin{array}{lllllll}\text { Dissolver Solution } & 0.027 & 0.003 & 0.044 & 0.007 & 0.012 & 0.57 \\ \text { Voloxdiation Off-Gas } & 25 & 28 & 29 & 28 & 10 & 31 \\ \text { DF } & 925 & 8450 & 665 & 4150 & 805 & 55\end{array}$

Carbon-14, C1/MIU

Dissolver off-Gas

$\begin{array}{lllll}0.024 & 0.022 & 0.023 \quad \text { Md } & 5 \times 10^{-4} & 0.039\end{array}$

Voloxidation Of $\mathrm{f}$-Gas

$\begin{array}{llllll}0.006 & 0.005 & 0.007 & 0.005 & 1 \times 10^{-5} & 0.004\end{array}$

$\%$ in Dissolver of $\mathrm{f}-\mathrm{Gas}$

80.9

80.3

77.6

M

98

91.3

Rryptan-85, CH/MrU

$\begin{array}{lllllll}\text { Dissolver off-Gas } & 377 & 388 & 396 & \text { M } & 5.1 & 944 \\ \text { Voloxidation Off-Gas } & 75 & 60 & 62 & 61 & 0.7 & 62 \\ \text { \% in Dissolver off-Gas } & 83.4 & 86.6 & 86.5 & \text { M } & 88.7 & 93.8\end{array}$

a. See Table 11 for measured background concentrations detemined from blank tests.

b. Iodine-129 data are not reported due to low reproductbility of data from low burnup fuel.

c. Partially oxidized fuel.

d. Not masured. 


\section{CHARACTERIZATION OF INSOLUBLE RESIDUE}

Total residue weights (solution plus rinse residues) measured from several dissolution tests, when plotted as a function of fuel burnup (Figure 9 and Table 15), showed that:

1) the residue weight increased approximately 1 inearly with fuel burnup for both voloxidized and nonvoloxidized fuel, and

2) the residue weight recovered from voloxidized fuel was about 2.2 times greater than the weight recovered from nonvoloxidized fuel.

The major elemental constituents of the residues, as determined by spark-source mass spectrometry (SSMS), were noble metal fission products of ruthenium, molybdenum, palladium, technetium, and rhodium (Table 16). The relative distributions of these fission products were not changed significantly in residues collected from voloxidized or nonvoloxidized fuels. Thus, voloxidation uniformly converts these fission products to more insoluble forms, which accounts for the higher total weight of the collected residue in dissolving voloxidized fuel. The data reported in Table 16 gives the weight percent range observed for each element in all tests with identical head-end treatment history. The sparksource data also showed that carbon contents of the solution residues were quite low (generally $<10 \%$ ), indicating the data in Figure 9 were not significantly affected by flocculant weight. The fission product distributions in the collected residues were found to be independent of total fuel exposure within the accuracy of the SSMS analysis (about 2 to $3 \mathrm{X}$ ).

The weight of the fission product residue collected after dissolution of the partially oxidized Oconee fuel $\left(\mathrm{U}_{4} \mathrm{O}_{9}\right)$ in Test 12 was intermediate between that for voloxidized and nonvoloxidized fuel (weight given in Table 15; refer to Figure 9). This result shows that the reduced solubility of noble metal fission products is directly dependent on the extent of oxidation and structure change of the fuel at the voloxidation temperature of $490^{\circ} \mathrm{C}$.

Rinses of the dissolver vessel generally yielded a small fraction of the total insoluble residue. For voloxidized fuels, this rinse residue is 5 to $10 \%$ of the total residue weight; for nonvoloxidized fuels, it is about $20 \%$ of the total weight (Table 15). The rinse residue usually had a high fraction of natural zirconium 


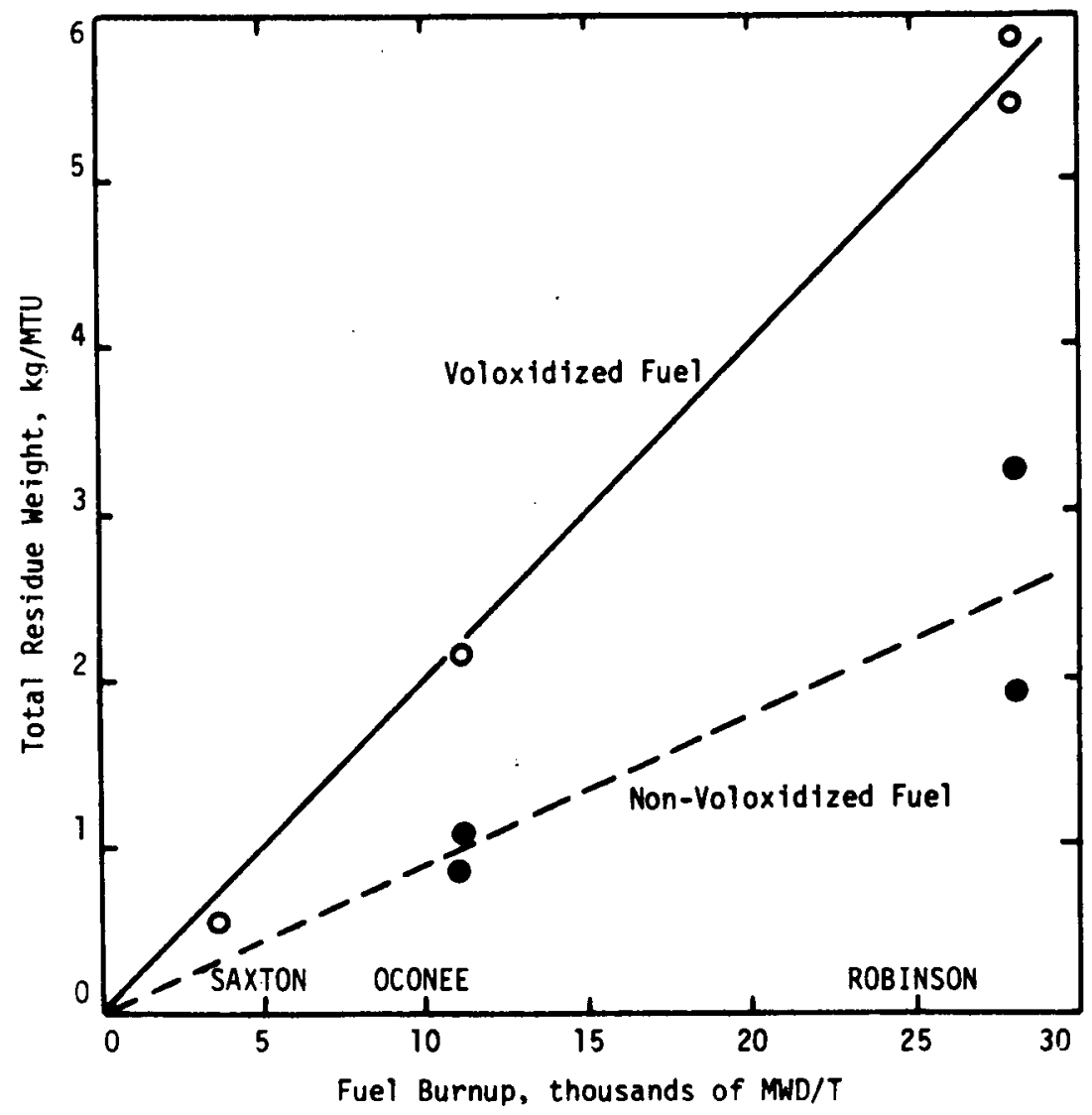

FIGURE 9. Insoluble Residue Collected after Fuel Dissolution v8. Fuel Burnup 
TABLE 14

Pu(IV) Concentration in Dissolver Solution at Various

T1me Intervals During and Following Dissolution

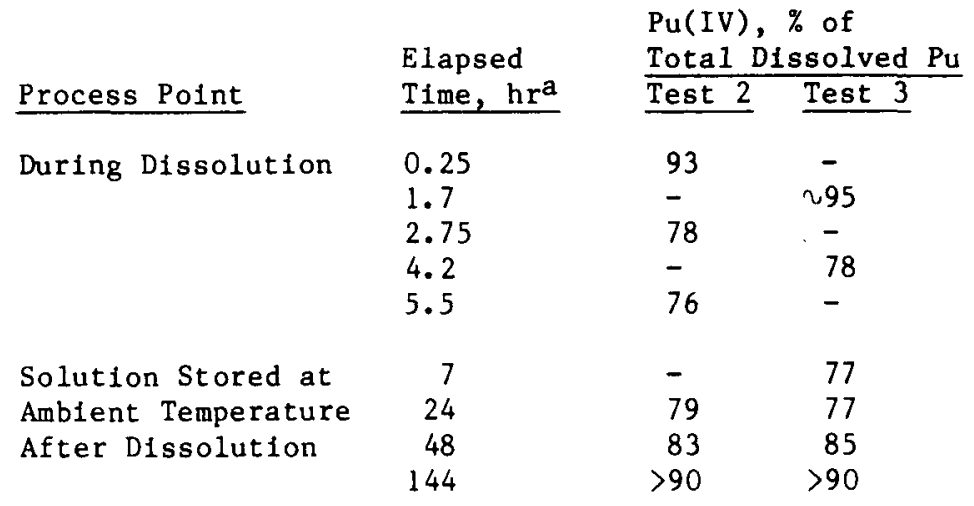

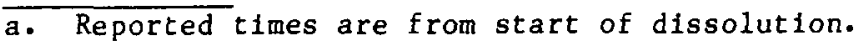

TABLE 15

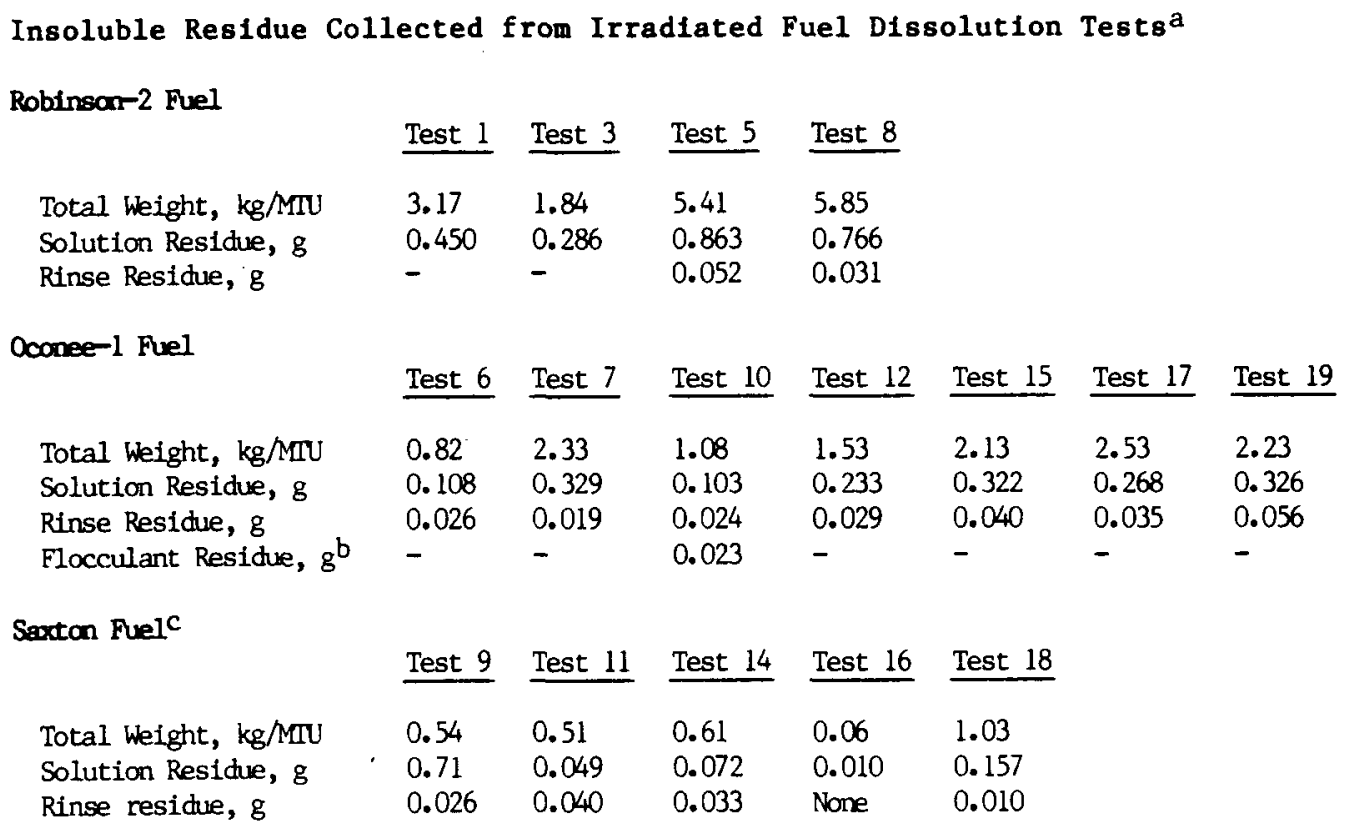

a. See experimental section for discussion of residue terminology.

b. Residue collected from previously centrifuged dissolver solution after addition of organic flocculant.

c. Residue weight from Test 13 was anomalously high $(4.1 \mathrm{~kg} / \mathrm{MTU})$; no explanation determined for high residue weight in that test (analysis showed no undissolved fuel). 
TABLE 16

Analysis of Insoluble Residues by Spark-Source Mass Spectrometrya,b

\begin{tabular}{|c|c|c|c|c|c|c|}
\hline $\begin{array}{l}\text { Voloxidized } \\
\text { Fuel } \\
\end{array}$ & $\begin{array}{l}\text { Robinson-2 } \\
\text { Solution } \\
\text { Residue } \\
\end{array}$ & $\begin{array}{l}\text { Euel, wt \% } \\
\text { Rinse } \\
\text { Res1due }\end{array}$ & $\begin{array}{l}\text { Oconee-1 } \\
\text { Solution } \\
\text { Residue } \\
\end{array}$ & $\begin{array}{c}\text { Fuel, wt \% } \\
\text { Rinse } \\
\text { Residue }\end{array}$ & $\begin{array}{l}\text { Saxton F } \\
\text { Solution } \\
\text { Residue } \\
\end{array}$ & $\begin{array}{l}\frac{1, \text { wt } \%}{\text { Rinse }} \\
\text { Residue }\end{array}$ \\
\hline${ }^{239} \mathrm{Pu}$ & $0.4 \pm 0.2$ & $0.2 \pm 0.1$ & $0.5 \pm 0.3$ & $0.6 \pm 0.4$ & 0.1 & $0.4 \pm 0.2$ \\
\hline${ }^{238} \mathrm{v}$ & $2 \pm 1$ & $2 \pm 1$ & $1.7 \pm 0.4$ & $1.2 \pm 0.2$ & $1 \pm 0.5$ & $2 \pm 1$ \\
\hline $\mathrm{Ag}$ & $0.8 \pm 0.3$ & $0.2 \pm 0.1$ & $1 \pm 0.9$ & $<0.1$ & $<0.02$ & $<0.02$ \\
\hline $\mathrm{Pd}$ & $7 \pm 3$ & $6 \pm 2$ & $5 \pm 3$ & $6 \pm 3$ & $6 \pm 1$ & $4 \pm 2$ \\
\hline $\mathrm{Rh}$ & $3 \pm 1$ & $2 \pm 1$ & $6 \pm 2$ & $5 \pm 1$ & $3 \pm 1$ & $2 \pm 1$ \\
\hline $\mathrm{Ru}$ & $22 \pm 3$ & $23 \pm 10$ & $28 \pm 5$ & $19 \pm 4$ & $14 \pm 4$ & $9 \pm 6$ \\
\hline Tc & $7 \pm 1$ & $4 \pm 3$ & $6 \pm 1$ & $4 \pm 1$ & $4 \pm 2$ & $2 \pm 1$ \\
\hline Mo & $17 \pm 3$ & $14 \pm 8$ & $20 \pm 5$ & $12 \pm 1$ & $4 \pm 3$ & $3 \pm 2$ \\
\hline $\mathrm{Zr}$ & $2 \pm 1$ & $1 \pm 0.5$ & $3 \pm 1$ & $5 \pm 1$ & $6 \pm 3$ & $10 \pm 5$ \\
\hline 0 & $\sim 15$ & $\sim 16$ & $\sim 12$ & $\sim 12$ & $\sim 20$ & $\sim 30$ \\
\hline C & $\sim 8$ & $\sim 6$ & $\sim 2$ & $\sim 7$ & $\sim 15$ & $\sim 6$ \\
\hline
\end{tabular}

Nonvoloxidized Fuel

$\begin{array}{lcccccc}{ }^{239} \mathrm{Pu} & \mathrm{ND}^{\mathrm{C}} & \mathrm{NM}^{\mathrm{c}} & \mathrm{ND}^{\mathrm{C}} & \mathrm{ND}^{-\mathrm{C}} & \mathrm{NM}^{\mathrm{c}} & \mathrm{NM}^{\mathrm{C}} \\ { }^{238 \mathrm{U}} & 2 \pm 1 & \mathrm{NM} & <0.04 & <0.04 & \mathrm{NM} & \mathrm{NM} \\ \mathrm{Ag} & 2 \pm 1 & \mathrm{NM} & 6 & 0.02 & \mathrm{NM} & \mathrm{NM} \\ \mathrm{Pd} & 5 \pm 2 & \mathrm{NM} & 5 & 4 & \mathrm{NM} & \mathrm{NM} \\ \mathrm{Rh} & 5 \pm 3 & \mathrm{NM} & 5 & 5 & \mathrm{NM} & \mathrm{NM} \\ \mathrm{Ru} & 30 \pm 10 & \mathrm{NM} & 26 & 22 & \mathrm{NM} & \mathrm{NM} \\ \mathrm{Tc} & 2 \pm 1 & \mathrm{NM} & 5 & 3 & \mathrm{NM} & \mathrm{NM} \\ \mathrm{Mo} & 13 \pm 3 & \mathrm{NM} & 27 & 13 & \mathrm{NM} & \mathrm{NM} \\ \mathrm{Zr} & 2 \pm 1 & \mathrm{NM} & 0.3 & 21 & \mathrm{NM} & \mathrm{NM} \\ \mathrm{O} & \sim 8 & \mathrm{NM} & \sim 8 & \sim 11 & \mathrm{NM} & \mathrm{NM} \\ \mathrm{C} & \sim 10 & \mathrm{NM} & \sim 6 & \sim 3 & \mathrm{NM} & \mathrm{NM}\end{array}$

a. Ranges indicated cover all data collected from several tests.

b. Mass assignments made to elements with highest calculated concentration by ORIGEN code.

c. $\quad$ ND = not detected; NM = not measured. 
(determined by isotopic composition), which probably resulted from cladding fines produced during shearing. These fines would be expected to have a larger particle size and thus settle more rapidly, thereby collecting in the dissolver heel. The fraction of zirconium contained in the residues based on the SSMS data generally represented $<0.1 \%$ of the total zirconium contained in the sheared fuel rod segments dissolved in any one test.

Mass balance calculations for ruthenium, although somewhat imprecise because ruthenium is distributed between the dissolver solution and the fission product residue, can predict whether significant quantities of ruthenium are volatilized during voloxidation. The calculation to determine ${ }^{106} \mathrm{Ru}$ activity in the insoluble residue is based on SSMS-measured weight fractions of total ruthenium in the residue ( 25 to 30 wt \% average). The ${ }^{106} \mathrm{Ru}$ weight is calculated based on ORIGEN calculated 16 weight fraction for $106 \mathrm{Ru}$ relative to all ruthenium isotopes (corrected for the actual decay time). Such calculations show that the reduced $106_{\mathrm{Ru}}$ concentration in solutions from voloxidized fuels can be accounted for by increased ${ }^{106} \mathrm{Ru}$ content in the insoluble residue. Acid leaching of the liner in the off-gas system does not yield significant quantities of ${ }^{106} \mathrm{Ru}$. This observation supports the hypothesis of minimal ruthenium volatilization during voloxidation, because any volatilized ruthenium should have plated out on the liner surfaces.

The ruthenium mass balances show that $<20 \%$ of the total ruthenium is dissolved from voloxidized fuel, while about $70 \%$ of the ruthenium is dissolved from nonvoloxidized fuel. This same behavior is expected for the other partially insoluble fission products based on SSMS data of the residues. Thus, voloxidation can be expected to fix a higher fraction of the noble metal fission products in solid residue waste, which minimizes the distribution of those fission products to other processing operations.

The solution residues from voloxidized fuel generally contained measurable fractions of plutonium (Table 17), as determined by $10 \mathrm{M} \mathrm{HNO}_{3}$ leaches of the residue. The uranium contained in these leaches was very low, indicating complete dissolution of the uranium fuel. For nonvoloxidized fuels, measured fractions of both uranium and plutonium in the leaches of the residues were very low. Thus, voloxidation converted a significant fraction $(0.15 \%$ to $0.3 \mathrm{wt} \%$ ) of the total plutonium to forms that were insoluble at the final dissolver acid concentrations ( 2 to $3 \mathrm{M} \mathrm{HNO}_{3}$ ). The amount of insoluble plutonium in the residue depended on the concentration of the final dissolver acid (Figure 10). Dissolving to low final acid concentration (about $1 \mathrm{M} \mathrm{HNO}_{3}$ ) yields significant quantities of insoluble plutonium ( 5 to $10 \%$ ) after the initial dissolution cycle. However, this insoluble plutonium was recovered 
TABLE 17

Characterization of Insoluble Residue by Acid Leachinga

Nonvoloxidized

Robinson-2b Oconee-1C
Voloxidized

Robinson-2d Oconee-1e Saxton $^{\mathrm{d}}$

1OM $\mathrm{HNO}_{3}$ Leach

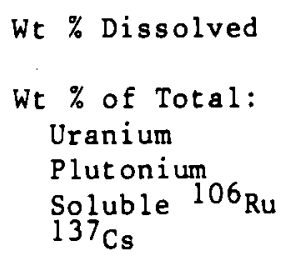

Wt \% Dissolved

Wt $\%$ of Total:

Uranium

Plut onium

Soluble ${ }^{106} \mathrm{Ru}$

$13{ }^{7} \mathrm{Cs}$

3.8

0.002

0.001

3.8

0.001
23.7

$<0.002$

$<0.005$

40.6

$<0.001$
7.8

0.003

0.30

3.3

0.01

59.5

$<0.001$

$<0.004$

16.3

17.7

0.001

$<0.001$

Total Soluble ${ }^{106} \mathrm{Ru}$, $\mathrm{dis} /(\min )(\mathrm{g} \mathrm{U}) \mathrm{g}$

Total Wt \%

Dissolved

by Leaches
$5.99 \mathrm{E} 10$

$2.81 E 10$

$2.24 E 10$

$1.27 \mathrm{E} 11$

$93.7 \%$

83.2

38.8

29.5

54.8

a. Data reported only for solution residues.

b. Data from Test 3 .

c. Data from Test 6 .

d. Data from Test 8 .

e. Data from Test 7 .

f. Data from Test 11 .

g. Includes ${ }^{106} \mathrm{Ru}$ in dissolver solution, $10 \mathrm{M} \mathrm{HNO}_{3}$ leach, and $\mathrm{HCl}$ leach of residue (not corrected for decay). 


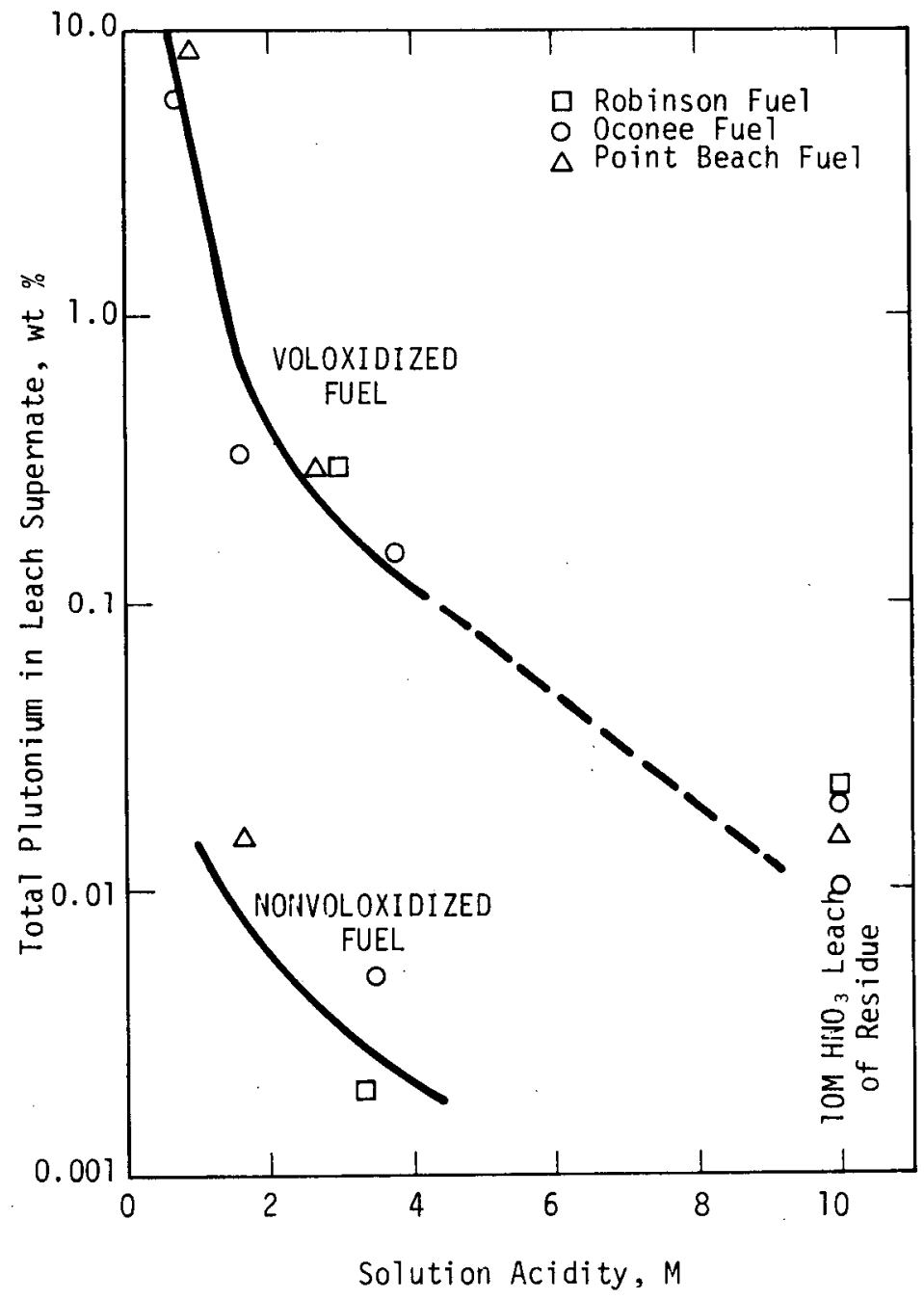

FIGURE 10. Plutonium Solubility in Voloxidized Fuel as a Function of Final Dissolver Acid Concentration 
easily by leaching with $10 \mathrm{M} \mathrm{HNO}_{3}$ in all tests. Subsequent leaches of the voloxidized fuel residues with concentrated $\mathrm{HCl}$ contained acceptably low plutonium concentrations (Table 17), indicating that very little insoluble plutonium remained in the residues after leaching with $10 \mathrm{M} \mathrm{HNO}_{3}$. Because a $10 \mathrm{M} \mathrm{HNO}_{3}$ leach of the spent hulls is included as part of the total dissolution process, recycle of the insoluble residues to this leach cycle will ensure high plutonium recovery from the voloxidized fuels.

Acid leaching of the rinse residues from dissolution of voloxidized fuels generally recovered much lower quantities of insoluble plutonium $(<0.05$ wt $\%)$. Thus, insoluble plutonium was preferentially carried with the very fine particulate residue (solution residue), which did not settle rapidly from the dissolver solution.

The only significant gamma-emitting fission product measured in the $10 \mathrm{M} \mathrm{HNO}_{3}$ leaches of the solution residues was $106_{\mathrm{Ru}}$, as would be expected based on SSMS characterization of the residues. The ${ }^{106} \mathrm{Ru}$ concentration in the residue leaches represented $<5 \%$ of the total soluble ${ }^{106} \mathrm{Ru}$ for voloxidized fuels and about $40 \%$ of the total soluble $106_{\mathrm{Ru}}$ for nonvoloxidized fuels (using Oconee fuel studies as a reference in Table 17): Weight measurements showed the nonvoloxidized fuel residue had a much higher solubility in $10 \mathrm{M} \mathrm{HNO}_{3}$ than the voloxidized fuel residue (about $23 \%$ vs. about $3 \%$ dissolved, respectively, for Oconee fuel). Thus, the leachability of all fission products in the insoluble residue was reduced significantly by the voloxidation treatment. This means that the fission product concentrations (including $106 \mathrm{Ru}$ ) in the voloxidized fuel dissolver solution will not be altered significantly by recycle of the $10 \mathrm{M} \mathrm{HNO}_{3}$ leach solution as part of the dissolver cycle.

The solubility behavior in concentrated $\mathrm{HCl}$ of the residues collected from voloxidized and nonvoloxidized fuels was similar to that observed in $10 \mathrm{M} \mathrm{HNO}_{3}$ (Table 17). The $\mathrm{HCl}$ leach solutions contained measurable quantities of $125 \mathrm{Sb}$ in addition to $106 \mathrm{Ru}$. SSMS data showed that the HCl leach solutions had fission product compositions approximately equivalent to the solid residue (mostly ruthenium and molybdenum). Thus, leaching appeared to dissolve the insoluble fission products uniformly from the solid residue.

In some tests the residue remaining after leaching with $10 \mathrm{M}$ $\mathrm{HNO}_{3}$ and concentrated $\mathrm{HCl}$ contained a high weight fraction (about 40 wt \%) of natural zirconium, indicating that zirconium fines formed during fuel shearing operations were not dissolved by the leach treatments. As discussed previously, the total weight of zirconium fines in the collected residues (based on SSMS data which has a factor of 2 to $3 \mathrm{X}$ accuracy) was $<0.1 \%$ of the total zirconium cladding weight used in any shearing test. 
A very small weight of insoluble residue was collected from the low burnup Saxton fuel of Test 16. The dissolver solution was relatively clear during this test, consistent with the low fuel burnup. SSMS characterization showed zirconium as the principal component of the residue $(32 \mathrm{wt} \%)$. The residue contained only traces ( $<2$ wt $\%$ ) of the noble metal fission products.

During the solvent extraction test with the dissolver solution from Test 1, a small quantity of black solid collected at the aqueous/organic interface in the extraction stages of the miniature mixer-settler bank, although the dissolver solution had been centrifuged two days before solvent extraction. SSMS analysis of the solid removed from the mixer-settler showed that the principal fission products were ruthenium and silver (Table 18). The high carbon content was probably due to organic contamination of the sample. It was not possible to wash or weigh the sample because of its low weight (probably $<10 \mathrm{mg}$ ).

SSMS analysis of the post-precipitation residue recovered after addition of organic flocculant to the dissolver solution from Test 10 (see Experimental Section) showed that the primary fission product components were ruthenium, palladium, and silver (Table 18). This residue composition is similar to the composition of the residue collected from the miniature mixer-settler banks in Test 1. The data demonstrate that the organic flocculant added to the dissolver solution removes fine particulate solids not removed by centrifuging alone and helps to prevent solids buildup in the solvent extraction banks.

Virtually all of the flocculant-recovered residue from Test 10 dissolved in $\mathrm{HCl}$. Uranium and plutonium concentrations in this leach were very low, indicating that significant amounts of the actinides were not precipitated in the dissolver solution after the initial centrifuging. The only measurable gamma-emitting fission product in the $\mathrm{HCl}$ leach solution was $106_{\mathrm{Ru}}$ (about $1.5 \%$ of the total $106_{\mathrm{Ru}}$ in the dissolver solution). 
TABLE 18

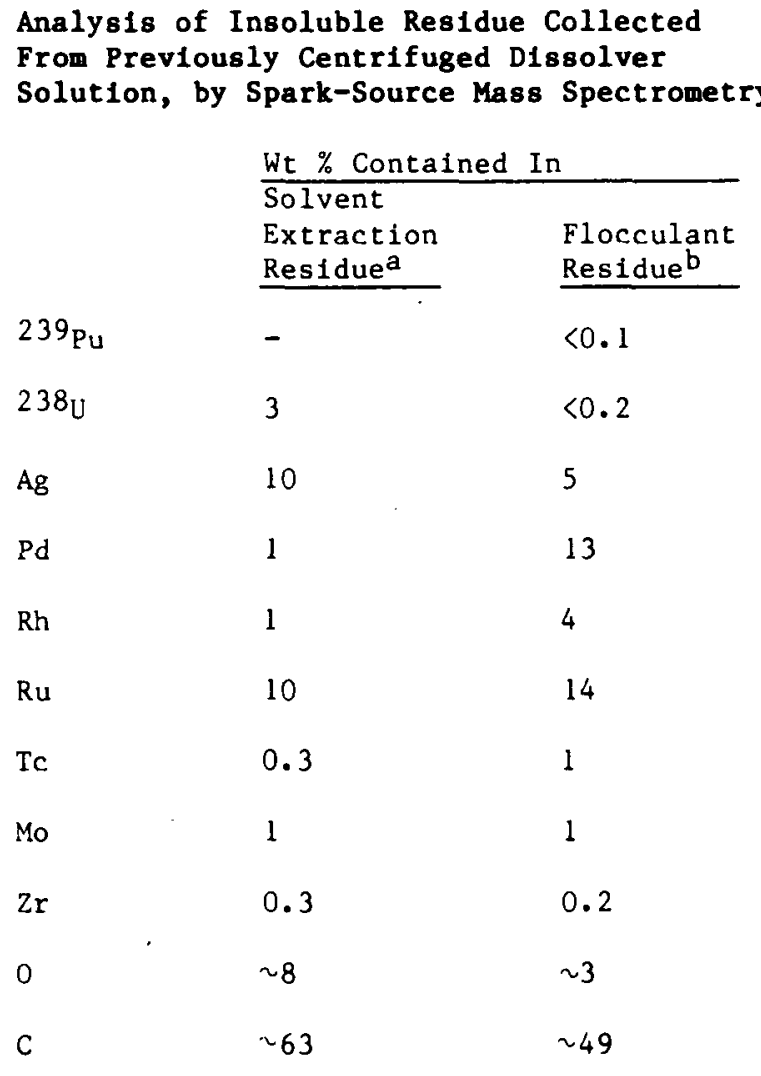

a. Sampled from aqueous/organic interface in feed stage of mini-mixer-settler bank (dissolver solution from Test 1 ).

b. Residue recovered from previously centrifuged dissolver solution after addition of organic. flocculant (Test 10); see feed clarification description in experimental section. 


\section{OFF-GAS CHARACTERIZATION}

\section{NO $_{x}$ Evolution}

Maximum instantaneous $\mathrm{NO}_{\mathrm{x}}$ evolution rates during fuel dissolution can be calculated from the maximum slopes of the dissolution rate data. Maximum dissolution rates in these tests generally occurred after initiating heating of the dissolver solutions (heating rates $\left\langle 3^{\circ} \mathrm{C} / \mathrm{min}\right.$ ). The dissolution reaction mechanisms of Reactions 2 and 3 for $\mathrm{NO}_{\mathrm{x}}$ evolution were used in making these calculations. The maximum calculated off-gas rates in all tests ranged between 30 to $60 \mathrm{scfm} / \mathrm{MTU}$. These off-gas rates are not expected to present processing problems.

\section{Tritium}

Nearly all of the tritium in the spent fuel was evolved to the off-gas during voloxidation 15 (Tables 11,12 , and 13). In most of the tests, greater than $99.8 \%$ of the tritium was removed by voloxidation. Small amounts of tritium remaining in the fuels after voloxidation were not released to the off-gas by dissolution, but were found as HTO in the dissolver solution. Tritium (as HTO) released to the off-gas system during dissolution was generally $<0.1 \%$ of the total measured tritium collected from the voloxidized spent fuel. Most of this tritium collected in the dissolver offgas is attributed to residual tritium contained in the off-gas system after voloxidation.

In two tests, the fraction of tritium evolved during voloxidation was somewhat $10 \mathrm{w}(87 \%$ in Test 10 with Oconee fuel and $98 \%$ in Test 18 with Saxton fuel). In both tests, conversion of $\mathrm{UO}_{2}$ to $\mathrm{U}_{3} \mathrm{O}_{8}$ was incomplete. In every test with complete conversion to $\mathrm{U}_{3} \mathrm{O}_{8}$, the tritium decontamination factor exceeded 650.15

Total tritium for each test is the sum of the amounts found in all off-gas traps and in the dissolver solution. Duplicate tests with Saxton rods gave good reproducibility. Total tritium from Robinson and Saxton fuels appear to be correlated with burnup, but tritium from Oconee fuel is less than expected on the basis of burnup.

Tritium in irradiated fuel arises principally from ternary fission and activation of $6_{\mathrm{Li}}$ impurities. Thus, total tritium will depend on the lithium impurity level and on the irradiation 
history of the fuel. A calculation with the ORIGEN code ${ }^{16}$ for Robinson fuel predicted about $470 \mathrm{Ci} / \mathrm{MTU}$ of tritium from fission and a comparable amount from activation. Observed amounts are less. Possible sources of variation in the results include: loss of tritium in earlier operations, such as shearing and storage; differences in burnup along a fuel rod; migration of tritium within a rod, because of thermal gradients; tritium trapped in the cladding; and uncertainities in the ORIGEN calculations.

\section{Carbon-14}

From 78 to $83 \%$ of ${ }^{14} \mathrm{C}$ in the fuels evolved during dissolution in most of the tests (Tables 11,12 , and 13). The remainder of the ${ }^{14} \mathrm{C}$ was released to the off-gas system during voloxidation. 15 The amounts found were 1000 times greater than the limit of detection for ${ }^{14} \mathrm{C}$, as determined by the control experiments. Duplicate tests with Saxton fuel showed that the measurements were reproducible.

${ }^{14} \mathrm{C}$ in irradiated fuels is formed primarily by the ${ }^{14} \mathrm{~N}(\mathrm{n}, \mathrm{p}){ }^{14} \mathrm{C}$ reaction on nitrogen impurities in the fuel and secondarily by the $17 \mathrm{O}(\mathrm{n},)^{14} \mathrm{C}$ reaction. Thus, the amount of ${ }^{14} \mathrm{C}$ produced depends on the amount of nitrogen impurity and on fuel burnup. A typical calculated value is $0.5 \mathrm{Ci} / \mathrm{MTU}$ for fuel with $20 \mathrm{ppm}$ nitrogen irradiated to about $30,000 \mathrm{MWD} / \mathrm{MTHM}$. The amounts of ${ }^{14} \mathrm{C}$ measured in Robinson, Oconee, and Saxton fuels are correlated with the burnups and are in the range expected for 10 to $20 \mathrm{ppm}$ nitrogen in the fuels.

\section{Krypton -85}

${ }^{85} \mathrm{Kr}$ evolved in the dissolver off-gas during dissolution of voloxidized Robinson, Oconee, and Saxton fuels 15 (Tables 11,12 , and 13 ) was found to be about $92 \%, 90 \%$, and $85 \%$, respectively, of the total measured $85 \mathrm{Kr}$. The low concentration of $85_{\mathrm{Kr}}$ evolved during voloxidation has been reported previously. 17

Apparent ly, the ${ }^{85} \mathrm{Kr}$ is dispersed throughout the fuel matrix as individual atoms instead of being collected as large bubbles at the grain boundaries. Oxidation of the $\mathrm{UO}_{2}$ does not release much of the ${ }^{85} \mathrm{Kr}$ from the matrix, even though a very fine $\mathrm{U}_{3} \mathrm{O}_{8}$ powder is formed. Since tritium is released completely under the same conditions, the results imply that krypton diffuses much slower than tritium through the $\mathrm{U}_{3} \mathrm{O}_{8}$ crystal lattice.

Total $85 \mathrm{Kr}$ in fuel is related to burnup, cooling period, and perhaps previous thermal history. A calculation with the ORIGEN code predicted about $7000 \mathrm{Ci} / \mathrm{MTU}$ of $85 \mathrm{Kr}$ for the Robinson fuel. The amounts of ${ }^{85} \mathrm{Kr}$ measured in Rovinson, Oconee, and Saxton fuels 
correlate very well with burnups but are somewhat lower than calculated values. An unknown amount of krypton may have been released on intial puncture of the rods and subsequent storage of the fuel.

\section{Iodine-129}

${ }^{129}$ I concentrations determined in the off-gas stream from several metal equipment dissolution tests with equivalent fuels were lower than those determined in the off-gas stream from glass equipment tests. This decrease was attributed to inefficient transfer of lodine to the silver zeolite trap in the metal equipment. In the tests with glass equipment using caustic scrubbers to trap the iodine, virtually all of the ${ }^{129} \mathrm{I}$ was found to be evolved from the solution during dissolution. Little difference was observed in those tests between the amount of ${ }^{129}$ I collected in the dissolver off-gas from voloxidized or nonvoloxidized fuels (Tables 11, 12, and 13). This conclusion is supported by characterization of the voloxidation off-gas. Small fractions of ${ }^{129} \mathrm{I}$, ranging from 0.1 to $7.9 \%$ of total collected ${ }^{129} \mathrm{I}$, were evolved during the voloxidation tests 15 (Tables 11 and 12).

\section{Semivolatile Fission Products}

Measured gamma-emitting fission product concentrations in the dissolver solution and the caustic scrubber traps of the glass equipment show that only minor amounts of semivolatile radionuclides are entralned in the off-gas stream (Table 19). Some concentration of ${ }^{106} \mathrm{Ru}$ in the off-gas did occur relative to $137 \mathrm{Cs}$ in all tests, indicating very slight volatility of ${ }^{106} \mathrm{Ru}$ during dissolution. 
TABLE 19

Gamma-Emitting Fission Products in Dissolver and off-Gas Caustic Scrubber Solutions ${ }^{a}$

Robinson-2 Fue1

Oconee 1 Fuel

Test 1 Test 3 Test 5 Test 6 Test 7

$106_{\mathrm{Ru}, \mathrm{d} 1 \mathrm{~s} / \mathrm{mln}}$

$\begin{array}{llllll}\text { Dissolver } & 2.0 \mathrm{E} 13 & 1.21 \mathrm{E} 13 & 2.55 \mathrm{E} 12 & 7.5 \mathrm{E} 12 & 2.63 \mathrm{E} 12 \\ \text { Scrubber } & 9.0 \mathrm{E} 07 & 5.4 \mathrm{E} 08 & 1.17 \mathrm{E} 09 & 9.7 \mathrm{E} 07 & 3.9 \mathrm{E} 06 \\ \% \text { in Scrubber } & 0.00045 & 0.0045 & 0.046 & 0.0013 & 0.00015\end{array}$

${ }^{137} \mathrm{Cs}, \mathrm{dis} / \mathrm{min}$

Dissolver

2. $3 \mathrm{E} 13$

$2.38 \mathrm{E} 13$

$2.88 \mathrm{E} 13$

1. $2 E 13$

Srrubber

3. $2 \mathrm{E} 07$

3. $0 \mathrm{E} 08$

2.10E09

$6.9 \mathrm{E} 07$

$1.25 \mathrm{E} 13$

$\%$ in Scrubber

0.00014

0.0013

0.0073

0.0006

7. $4 \mathrm{E} 06$

$144 \mathrm{Ce}, \mathrm{d}$ is/min

$\begin{array}{llllll}\text { Dissolver } & 3.1 \mathrm{E} 13 & 2.23 \mathrm{E} 13 & 2.37 \mathrm{E} 13 & 2.4 \mathrm{E} 13 & 2.08 \mathrm{E} 13 \\ \text { Scrubber } & 1.3 \mathrm{E} 07 & 4.23 \mathrm{E} 08 & 2.55 \mathrm{E} 08 & 4.4 \mathrm{E} 07 & \text { ND }^{\mathrm{b}} \\ \% \text { 1n Scrubber } & 0.00004 & 0.0019 & 0.0011 & 0.0002 & <0.00005\end{array}$

a. No corrections for decay of fission products.

b. Not detected. 


\section{EXPERIMENTAL}

\section{Dissolution Equipment}

Glass Apparatus. Glass dissolution equipment (Figure 11) used for Tests 1 to 7 in the high-level shielded facilities consisted of a 4-L reaction kettle connected to a series of four traps: a condensate trap, two $6 \mathrm{M} \mathrm{NaOH}$ scrubber traps, and a silica gel bed. An air sparge was drawn down a dip leg through the solution by vacuum. The off-gas stream passed through a reflux condenser to the series of traps to remove iodine and other volatile radionuclides (except $85 \mathrm{Kr}$ ).

Voloxidizer-Dissolver. Metal equipment located in a shielded cell and coupled to off-gas handling equipment was used for all other voloxidation/dissolution tests. 15 This equipment consisted of a 2-L cavity in a stainless steel block which contained numerous heaters, thermocouples, and cooling coils for flexible operation (Figure 12). The equipment was designed so that fuel voloxidation and dissolution could be done in the same vessel without handling of fuel between each operation. The reaction chamber rotates on a horizontal axis to provide two operating positions: tilted, as shown in Figure 12, for voloxidation; or vertically upright for dissolving.

off-Gas System. The voloxidizer-dissolver is coupled to laboratory-scale off-gas equipment both inside and outside the shielded cell; the arrangement for dissolution is shown schematically in Figure 13. The arrangement for voloxidation is similar. 15 This arrangement provides a closed gas-recirculating system with helium as a carrier gas. Oxygen may be added to the recirculating gas, if desired, to simulate air sparging during dissolution. The recirculating gas enters the dissolver through a submerged hollow shaft assembly to provide a solution sparge. The dissolution offgas exits the dissolver through a reflux condenser and is carried with the recirculating gas to the off-gas collection traps.

Two Type $3 \mathrm{~A}$ molecular sieve traps located in a hood outside the shielded cell collect tritium as HTO. An oxidizing bed of $\mathrm{CuO}$ at $300^{\circ} \mathrm{C}$ is placed between the traps to convert any HT to HTO. Hydrogen $g$ as is introduced into the off-gas recirculation lines to act as a carrier for HT.

Two Type $13 \mathrm{X}$ molecular sieve traps collect ${ }^{14} \mathrm{C}$ as ${ }^{14} \mathrm{CO}_{2}$. These traps also are outside the shielded cell, one on each side of the heated CuO bed. Any ${ }^{14} \mathrm{CO}$ in the offgas is oxidized to 


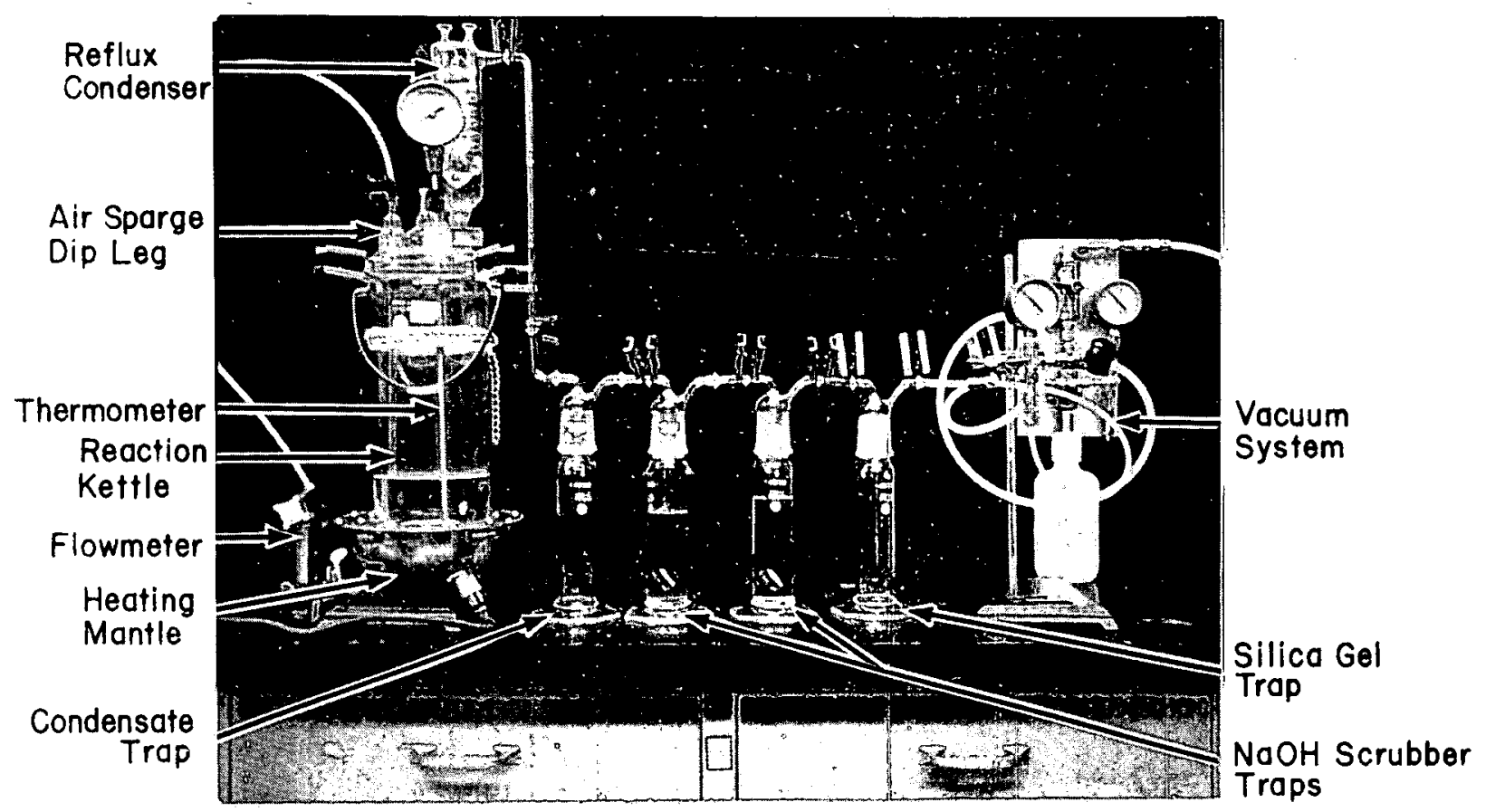

FIGURE 11. Glass Apparatus for Dissolution Tests in High Level Shielded Cells 


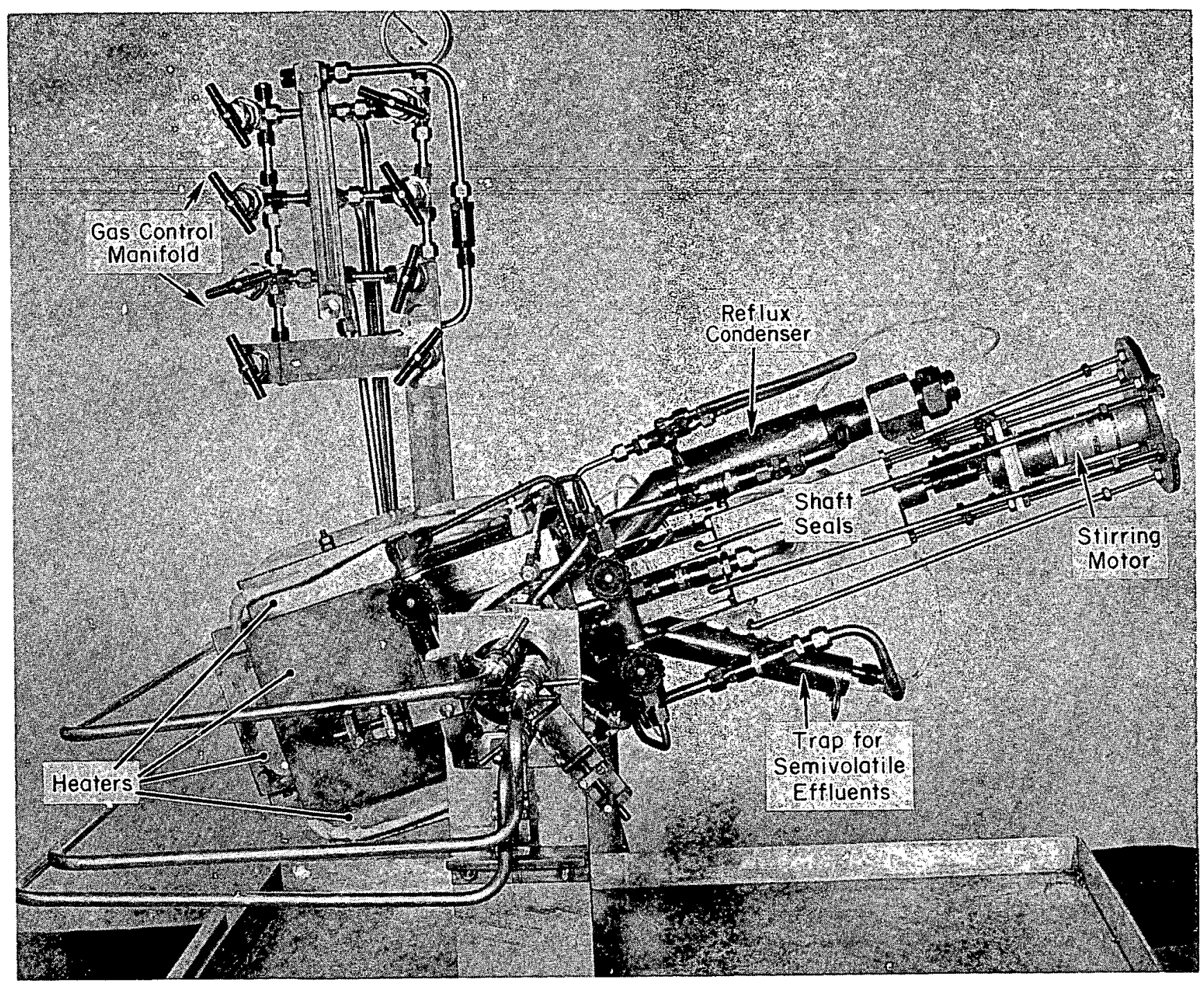

FIGURE 12. Metal Voloxidation/Dissolution Equipment for Dissolution Tests in High Level Shielded Cells 


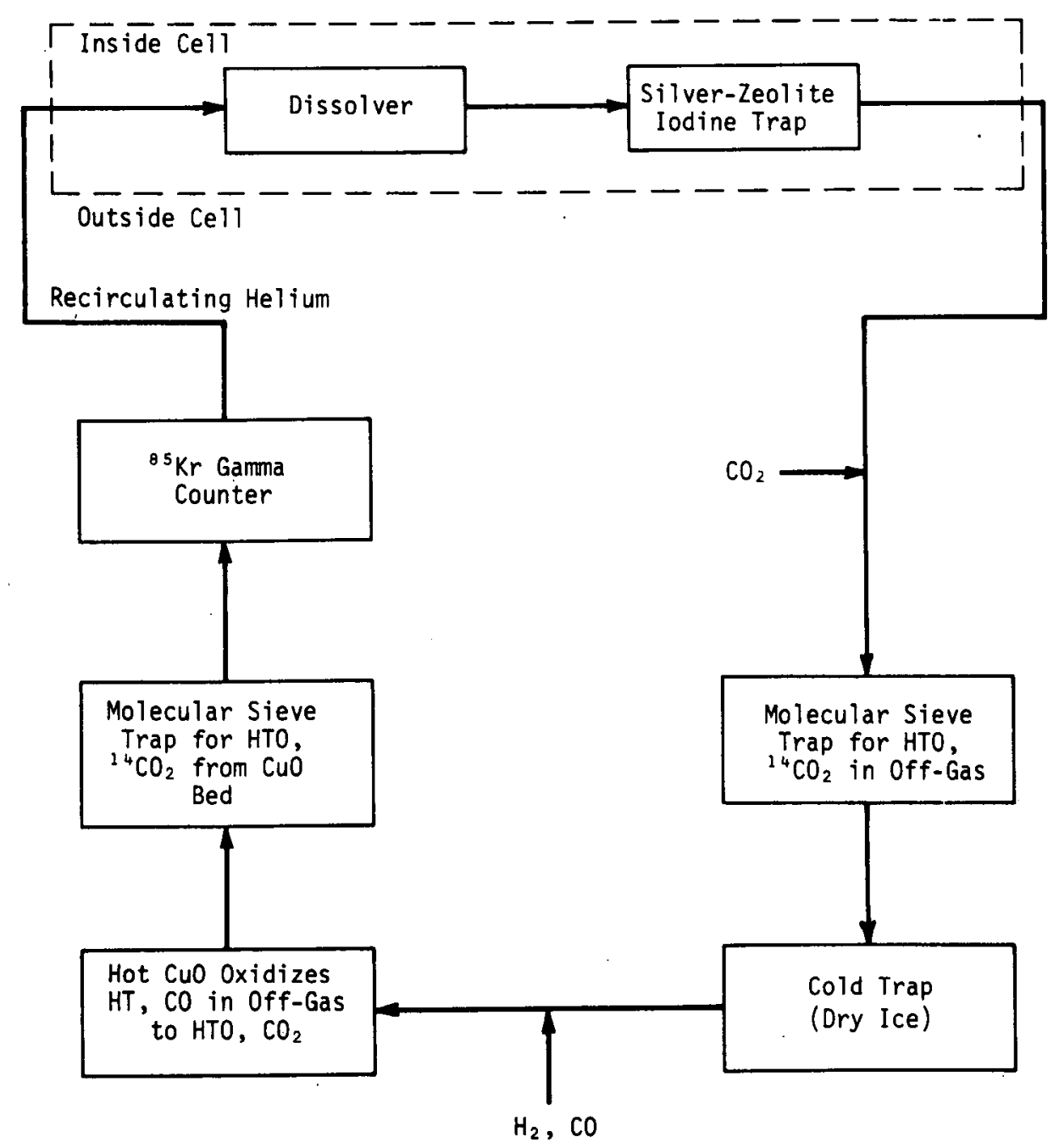

FIGURE 13. Dissolver off-Gas System 
${ }^{14} \mathrm{CO}_{2}$ and collected in the second trap. Carrier gases are added: $\mathrm{CO}_{2}$ before the first trap and $\mathrm{CO}$ before the $\mathrm{CuO}$ bed.

The off-gas circulates through a calibrated chamber for counting the $514-\mathrm{keV}$ gamma ray of $85 \mathrm{Kr}$ with a high-resolution $\mathrm{Ge}-\mathrm{Li}$ detector.

A bed of silver-exchanged zeolite $\left(\mathrm{Ag}^{\circ}-\mathrm{X}\right)$ at $180^{\circ} \mathrm{C}$ located in the shielded cell is used to trap iodine from the off-gas stream. This trap is close-coupled to the dissolver of $\mathrm{f}$-gas exit to minimize potential deposition of iodine in the stainless-steel lines of the off-gas system.

The off-gas system was tested and calibrated with tracer amounts of radioactive gases before the first test with irradiated fuel. The system is leak tested prior to each dissolution test.

\section{Dissolution Procedures}

Sheared fuel pieces, unclad $\mathrm{UO}_{2}$ fuel fragments, or powdered $\mathrm{U}_{3} \mathrm{O}_{8}$ were charged directly to the glass or metal reaction vessel before initiating the dissolution process. For most tests, acid volumes, acid addition rates, and solution temperature changes were made to agree with the batch dissolution process described on page 14 (see Tables 2, 4, and 6 for fuel dissolution conditions). $10 \mathrm{M} \mathrm{HNO}_{3}$ was added at a controlled rate with a standard metering pump. For Tests 5 to 19 , the $10 \mathrm{M} \mathrm{HNO}_{3}$ addition was initiated immediately after the initial batch acid charge ( 1 to $3 \mathrm{M} \mathrm{HNO}_{3}$ ), and was generally completed in 60 to 75 minutes. In those tests, the solution temperature was increased from ambient cell temperature $\left(25\right.$ to $\left.35^{\circ} \mathrm{C}\right)$ to $90^{\circ} \mathrm{C}$ at 90 minutes after the initial acid charge to the dissolver. Total dissolution time was generally 3.5 to 4.5 hours, including one to two hours at $90^{\circ} \mathrm{C}$ to ensure complete fuel dissolution.

For Tests 3 and 4 , the $10 \mathrm{M} \mathrm{HNO}_{3}$ addition was not initiated until about one hour after the initial acid charge. This procedure was intended to determine if acid depletion due to rapid dissolution rates could occur at the initial batch acid concentrations ( 2 to $3 \mathrm{M} \mathrm{HNO}_{3}$ ).

For Tests 1 and 2 , about $6 \mathrm{M} \mathrm{HNO}_{3}$ was batch-charged to the fuel, and solution temperature was increased to $90^{\circ} \mathrm{C}$ soon after charging the acid, to simulate a conventional batch dissolution flowsheet.

During Test 3 , the initial $2 \mathrm{M} \mathrm{HNO}_{3}$ charge in the dissolver was heated to increase the dissolution rate. When dissolution rate increased (as evidenced by $\mathrm{NO}_{x}$ evolution), heating was 
stopped until the addition of $10 \mathrm{MNO}_{3}$ was completed. Maximum solution temperature achieved was $48^{\circ} \mathrm{C}$. The solution temperature slowly decreased to $42^{\circ} \mathrm{C}$ after the heating was stopped, indicating that the exothermic dissolution reaction could not sustain the solution temperature.

For Test 12, the heaters were inadvertently turned on immediately after the $1 \mathrm{M} \mathrm{HNO}_{3}$ charge to the dissolver. Solution temperature increased to about $60^{\circ} \mathrm{C}$ during the initial 20 minutes of the dissolution. When the temperature increase was discovered, the solution was cooled to ambient cell temperature within 40 minutes of the initial acid charge to slow dissolution. The solution was heated after 90 minutes as required by normal procedure.

For Tests 13, 14, and 15, the initial acid charge was reduced to $0.5 \mathrm{M} \mathrm{HNO}_{3}$, and the volume of metered $10 \mathrm{M} \mathrm{HNO}_{3}$ was reduced (Tables 4 and 6) to determine whether $\mathrm{UO}_{2}$ fuels (as $\mathrm{U}_{3} \mathrm{O}_{8}$ powder) could be dissolved completely with the final acid concentration in the dissolver at 0.8 to $1.0 \mathrm{M} \mathrm{HNO}_{3}$. Low acid concentrations are desirable because they increase zirconium decontamination if $\mathrm{MnO}_{2}$ precipitation is used for head-end clarification. However, acid concentration could not be kept in the desired range because $\mathrm{NO}_{2}$ was recirculated in the closed off-gas system and redissolved. For Tests 16 and 17 , the metered acid concentration was reduced to $8.5 \mathrm{M} \mathrm{HNO}_{3}$ to balance approximately the known increase in acid concentration from dissolved $\mathrm{NO}_{2}$, yielding a desired final dissolver acid concentration of $0.8 \mathrm{M} \mathrm{HNO}_{3}$.

An air sparge rate of approximately one-half the solution volume per minute $(200$ to $250 \mathrm{cc} / \mathrm{min}$ ) was maintained in all tests. No problems were encountered with this sparging rate using smallscale equipment. However, on a plant scale, a lower sparging rate during dissolution would be acceptable. Experimental studies at ORNL have shown that: 1) the $\mathrm{NO}_{x}$ evolution rate is sufficient to remove most iodine, and 2 ) the remaining iodine can be removed efficiently if the solution is sparged after dissolution. 18

After dissolution, the raw metal solution was removed from the dissolver vessel. The spent hulls, if present, were rinsed twice with $1 \mathrm{M} \mathrm{HNO}_{3}$ ( $250 \mathrm{~mL}$ each time), and then were leached with $250 \mathrm{~mL} 10 \mathrm{M} \mathrm{HNO}_{3}$ at $90^{\circ} \mathrm{C}$ for four hours to recover undissolved actinides. Insoluble residue generally was observed in the first rinse solution and, in some cases, in the second rinse solution. The $10 \mathrm{M} \mathrm{HNO}_{3}$ leach solution generally did not contain solids.

Small quantities of fine fuel particles $\left(\mathrm{UO}_{2}\right.$ or $\left.\mathrm{U}_{3} \mathrm{O}_{8}\right)$ were unavoidably included with some dissolver solution samples taken to determine uranium dissolution rate. These fuel particles continued to dissolve in the sample vials, even at room temperature, as evidenced by higher-than-expected uranium concentrations and 
lower-than-expected acid concentrations from the sample analysis. This problem was particularly evident at shorter dissolution times. Thus, dissolution rates determined from uranium data represent an upper limit for the amount of fuel expected to be dissolved at a given time. Removal of the solids during sampling was not attempted because of difficulties associated with remote operation in the shielded cells.

\section{Feed Clarification}

When removed from the dissolver vessel, the raw dissolved fuel solution is black and opaque due to suspended insoluble solids (Figure 14). During Test 1, this solution could not be clarified by filtration through a fine-pore glass frit, indicating residue particle size $<5 \mu \mathrm{m}$. After centrifuging the solution (about $1500 \mathrm{G}$ ), a clarified supernate which retained some dark color was obtained (Figure 14). During solvent extraction tests with this clarified solution, a small quantity of black solid ("crud") collected at the aqueous/organic interface in the extraction stages of the miniature mixer-settler bank. The centrifuged solution had aged only two days prior to the solvent extraction tests.

The observations from Test 1 led to the development of a process for using organic flocculant to clarify dissolved fuel solutions. 19 The flocculant used to clarify all dissolver solutions in these tests was Primafloc ${ }^{\circledR} \mathrm{C}-3$ (Rohm and Haas). The flocculant was added to the dissolver solution at a $200 \mathrm{ppm}$ solution, based on total dissolver solution weight.

Some of the Oconee fuel solutions were clarified by different procedures to test the effectiveness of the organic flocculant for removing the fine particulate solids. The feed solution from Test 15 was centrifuged to recover the residue without any addition of organic flocculant. After aging for two weeks with no further clarification treatment, the feed was used in a solvent extraction test. Sma11 amounts of solid were observed at the organic/aqueous interface throughout the extraction stages of the $1 \mathrm{~A}$ mixer-settler during that test. The dissolver solution from Test 12 was centrifuged after adding organic flocculant. That solution was aged eleven weeks with no further clarification prior to a solvent extraction test. No solids were observed during the subsequent solvent extraction test.

For Test 10 the dissolver solution was centrifuged within one day of the dissolution test without addition of organic flocculant. After standing at ambient temperature for 18 days, organic flocculant was added and the solution was centrifuged again. This procedure recovered a solid representing about $13 \%$ of 


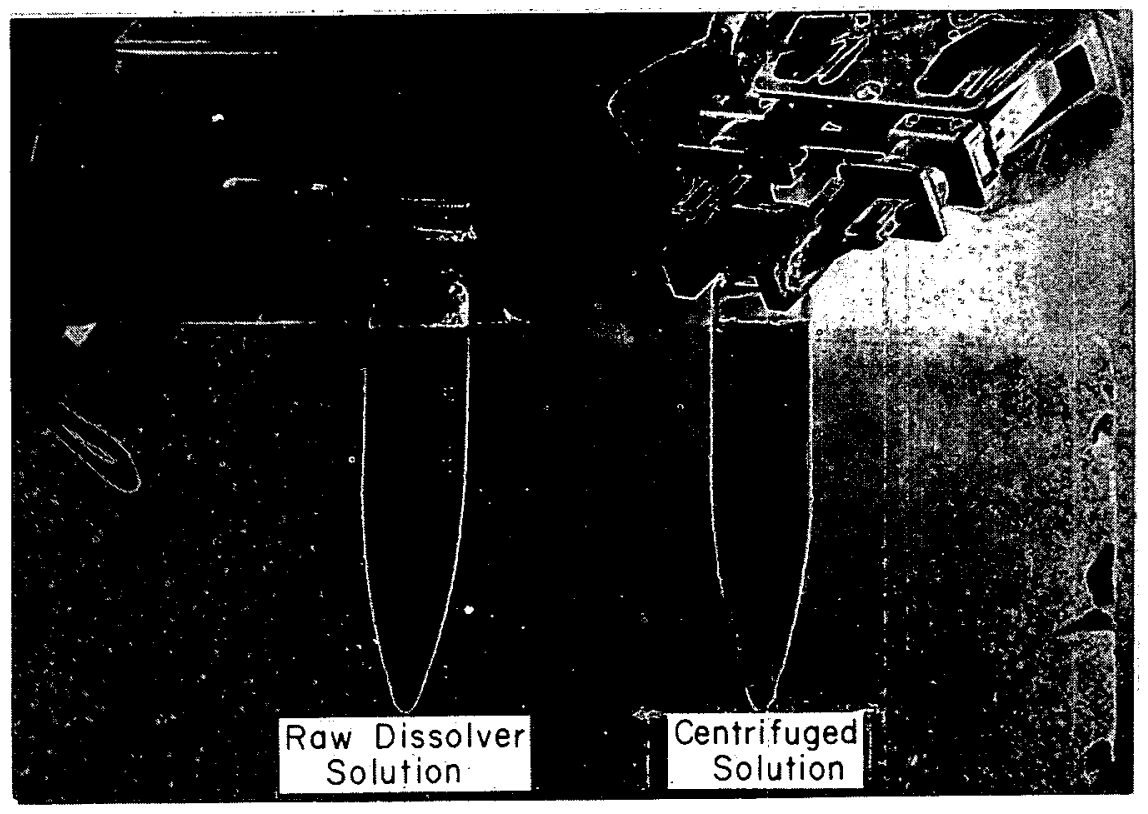

FIGURE 14. Clarification of Dissolver Solution by Centrifugation 
the total residue weight. The flocculant-clarified solution was used as a feed for a solvent-extraction test; no solids were observed in the mixer-settler banks during that test.

These tests demonstrate the effect of the organic flocculant in clarifying the feed solutions and avoiding any precipitation of solids which could adversely affect solvent extraction. Solids buildup in the mixer-settler banks has not been observed in any test with flocculant-clarified solutions, regardless of solution aging period.

\section{Insoluble Residue Characterization}

Insoluble residues centrifuged from the dissolver solutions are termed solution residues. The residues centrifuged from the IM $\mathrm{HNO}_{3}$ rinses of the dissolver vessel and spent hulls are termed rinse residues. Each residue, collected separately in centrifuge cones, was washed carefully with $0.5 \mathrm{M} \mathrm{HNO}_{3}$ before drying to determine total weight. After weighing, small quantities (10 to $20 \mathrm{mg}$ ) were sampled for Spark Source Mass Spectrometry (SSMS) analysis. The residues then were leached in the centrifuge cones with $10 \mathrm{~mL}$ of $10 \mathrm{M} \mathrm{HNO} 3$ at $90^{\circ} \mathrm{C}$ for 6 hours with occasional vortex mixing to remove soluble actinides and fission products. After leaching, the residues were washed and dried for weighing. In some cases, a second leach treatment followed with $10 \mathrm{~mL}$ of concentrated $\mathrm{HCl}$ at $90^{\circ} \mathrm{C}$ for 6 hours to test for any remaining insoluble actinides.

\section{Analytical Techniques}

Solution uranium concentrations were determined by colorimetric and/or titrametric methods. 20 Solution acid concentrations were determined by potentiometric acid/base titration procedures. After valence adjustment with ferrous sulfamate, plutonium was extracted from dissolver solutions as Pu(IV) into $0.5 \mathrm{M}$ thenoyltrifluoroacetone (TTA) in xylene, and then stripped into $8 \mathrm{M} \mathrm{HNO}_{3}$ for analytical determination by alpha counting and alpha pulse height analysis. Absolute plutonium concentrations were calculated from alpha counting data using isotopic distributions measured by mass spectrometry. Fission product distributions in solutions were determined by standard gamma pulse height analysis.

Tritium in solution as HTO was determined by liquid scintillation counting after decontamination from fission products by deionization with a mixture of cation and anion exchange resins. 21 Iodine in solutions was determined by neutron activation analysis after wet chemical isolation. Characterization of solid 
residues for fission product distributions was made by spark source mass spectrometry techniques.

After each voloxidation or dissolution test, tritium, ${ }^{14} \mathrm{C}$, and ${ }^{129} \mathrm{I}$ trapped by the off-gas system were removed from their primary sorbents by a heat treatment. 15 The methods used are summarized in Table 20. HTO and ${ }^{14} \mathrm{CO}_{2}$ were desorbed from molecular sieve pellets to obtain forms suitable for liquid scintillation beta-counting. Used pellets were discarded.

Because silver interferes with neutron-activation analysis for ${ }^{129} \mathrm{I}$, the iodine was removed from silver zeolite as HI and resorbed on lead zeolite, which does not interfere. 15 This method was adapted from the work of Staples, Murphy, and Thomas.22,23 The regenerated silver-zeolite traps were reused.

TABLE 20

Analyses for Gaseous Radioactive Species

Collected in Off-Gas System

\begin{tabular}{|c|c|c|c|c|c|}
\hline Radionuclide & $\begin{array}{l}\text { Primary } \\
\text { Sorbent }\end{array}$ & Bakeout $^{a}$ & $\begin{array}{l}\text { Carrier } \\
\text { Gas }\end{array}$ & $\begin{array}{l}\text { Secondary } \\
\text { Trap }\end{array}$ & $\begin{array}{l}\text { Analytical } \\
\text { Method }\end{array}$ \\
\hline $3_{\mathrm{H}}$ & $3 \mathrm{~A}$ & Yes & $\mathrm{H}_{2}{ }^{\mathrm{O}}$ & Cold Trap & $\beta$ counting \\
\hline${ }^{14} \mathrm{C}$ & $13 x$ & Yes & $\mathrm{CO}_{2}$ & $\mathrm{CO}_{2 \mathrm{~m}} \mathrm{MET}^{\mathrm{c}, \mathrm{d}}$ & $\beta$ counting \\
\hline${ }^{85} \mathrm{Kr}$ & - & - & He & - & $\begin{array}{l}\text { Online } \gamma \\
\text { counting }\end{array}$ \\
\hline${ }^{129} \mathrm{I}$ & $\mathrm{Ag}^{\circ}-\mathrm{X}$ & Yes $^{e}$ & $\mathrm{H}_{2}$ & $\mathrm{~Pb}-\mathrm{X}\left(150^{\circ} \mathrm{C}\right)$ & $\begin{array}{l}\text { Neutron } \\
\text { activation }\end{array}$ \\
\hline
\end{tabular}

a. Heat treatment at $500^{\circ} \mathrm{C}$ for 8 to 16 hours.

b. Refrigerated to $-50^{\circ} \mathrm{C}$.

c. Trademark of Amersham/Searle carbon dioxide trapping agent.

d. Preceded by cold trap for $\mathrm{H}_{2} \mathrm{O}$.

e. Heated at $500^{\circ} \mathrm{C}$ with flowing hydrogen gas. 
REFERENCES

1. G. W. Gibson, B. A. Murdock, W. J. Quapp, R. B. Hobbins, and R. H. Isling (comps.). Characteristics of $\mathrm{UO}_{2}-$ Zircaloy Fuel Rod Materials from the Saxton Reactor for Use in Power Burst Facility. ANCR-NUREG-1321, Idaho National Engineering Lab, Idaho Falls, Idaho (September 1976).

2. Saxton Plutonium Program Quarterly Progress Reports. Series WCAP-3385-1 to 3385-37, Westinghouse Electric Corporation, Pittsburgh, Penn. (October 1964 to December 1973).

3. A. Bianchera, et al. Saxton Plutonium Program. Materials Design and Fabrication of the Saxton Partial Plutonium Core. WCAP-3385-53, Westinghouse Electric Corporation, Pittsburgh, Penn. (December 1965).

4. W. R. Smalley. Saxton Core II Fuel Performance EvaluationPart I-Materials. WCAP-3385-56 (Part I), Westinghouse Electric Corporation, Pittsburgh, Penn. (September 1971).

5. W. R. Smalley. Evaluation of Saxton Core III Fuel Materials Performance. WCAP-3385-57, Westinghouse Electric Corporation, Pittsburgh, Penn. (Ju1y 1974).

6. H. C. Honeck. The JOSHUA System. USAEC Report DP-1380, E. I. du Pont de Nemours and Company, Savannah River Laboratory, Aiken, S. C. (1975).

7. T. C. Gorrell and D. P. Falconer. Use of Measured Actinide Contents for Inferring Exposure of LWR Fuel. Paper presented at the ANS Topical Meeting on Back End of the LWR Fuel Cycle, Savannah, Georgia (March 19-22, 1978).

8. Reprocessing of the Dresden Reactor Fuel at Nuclear Fuel Services, Inc. USAEC Report SRO-123 (1968).

9. Reprocessing of Yankee Reactor Fuel at Nuclear Fuel Services, Inc. USAEC Report SRO-124 (1968).

10. Barnwell Nuclear Fuel Plant, Separations Facility, Final Safety Analysis Report. Docket No. 50-332, Vol. II, Section 4, Allied-General Nuclear Services, Barnwell, S. C. (1973). 
11. Aqueous Processing of LMFBR Fuel. Technical Assessment and Experimental Program Definition. USAEC Report ORNL-4436, Oak Ridge National Laboratory, Oak Ridge, Tennessee (1970).

12. R. F. Taylor, E. W. Sharratt, L. E. M. de Chazal, and D. H. Logsdail. "Dissolution Rates of Uranium Dioxide Sintered Pellets in Nitric Ac1d Systems." J. App1. Chem., 13, 32 (1963).

13. M. Shabbir and R. G. Robins. "Kinetics of the Dissolution of Uranium Dioxide in Nitric Acid-I." J. App1. Chem., 13, 129 (1968).

14. M. Shabbir and R. G. Robins. "Kinetics of the Dissolution of Urantum Dioxide in Nitric Acid-II." J. Appl. Chem., 19, 52 (1969).

15. J. A. Stone and D. R. Johnson. "Measurement of Radioactive Gaseous Effluents from Voloxidation and Dissolution of Spent Nuclear Fuel." Proceedings of the 15th DOE Nuclear Alr Cleaning Conference, Boston, Massachusetts, August 7-10, 1978. USDOE Report CONF-780819, pp 570-583 (1979).

16. M. J. Be11. ORIGEN - The ORNL Isotope Generation and Deplet1on Code. USAEC Report ORNL-4628, Oak Ridge National Laboratory, Oak Ridge, Tennessee (1973).

17. J. H. Goode, Ed., Voloxidation - Removal of Volatile F1ssion Products from Spent LMFBR Fuels. USAEC Report ORNL-TM-3723, Oak Ridge National Laboratory, Oak Ridge, Tennessee (1973).

18. LWR Fuel Reprocessing and Recycle Program - Quarterly Report No. 3. USERDA Report ORNL-TM-5660, Oak Ridge National Laboratory, Oak Ridge, Tennessee (1976).

19. M. J. Plodinec. "Clarification of LWR Solutions." Paper presented at the ANS Topical Meeting on Back End of the LWR Fuel Cycle, Savannah, Georg1a, March 19-22, 1978.

20. A. R. Eberle, M. W. Lerner, C. G. Goldbeck, and C. J. Rodden. Titrametric Determination of Uranium in Product, Fuel and Scrap Materials after Ferrous Ion Reduction in Phosphoric Acid. USAEC Report NBL-252, New Brunswick Laboratory, New Brunswick, New Jersey (1970). 
21. E. W. Baumann and K. W. MacMurdo. "Determination of Tritium in Solutions from Nuclear Reprocessing." Analytical Chemlstry In Nuclear Fuel Reprocessing. W. S. Lyon, Ed., Science Press, Princeton, New Jersey, p 252 (1978).

22. B. A. Staples, L. P. Murphy, and T. R. Thomas. "Alrborne Elemental Iodine Loading Capacities of Metal Zeolites and a Dry Method for Recycling Silver Zeolite." Proceedings of the 14th ERDA Alr Cleaning Conference, Sun Valley, Idaho, August 2-4, 1976. USERDA Report CONF-760822, pp 363-379 (1977).

23. T. R. Thomas, B. A. Staples, L. P. Murphy, and J. T. Nichols. Alrborne Elemental Iodine Loading Capacities of Metal Zeolites and a Method for Recycling Silver Zeolite. USERDA Report ICP-1119, Idaho National Engineering Laboratory, Idaho Falls, Idaho (1977). 


\section{APPENDIX A: FUEL SHEARING}

Figure 1A shows the single pin hydraulic shear used for several tests in the high level caves. A manually-operated pump outside the shielded cell provides up to 2000 psig pressure. The tray beneath the jaws catches sheared segments of the fuel rods and dislodged $\mathrm{UO}_{2}$ fragments.

The fuel rods were sheared into one-inch segments for most voloxidation/dissolution tests (a few tests used pieces up to 1.5 inches long). The Zircaloy 4 cladding was only slightly deformed ( $<20 \%$ closure) during shearing (Figure $2 A$ ). Severely pinched cladding ends which could reduce voloxidation or dissolution rates significantly were not observed during any test. As a result of shearing, about $43 \%, 35 \%$, and $95 \%$ of the Robinson, Oconee, and Saxton $\mathrm{UO}_{2}$ fuels, respectively, were broken into fragments which fell out of the sheared pieces. Maximum pressures which were required to cut the fuel rods varled between 300 and 1300 psig with average pressures generally in a range of 700 to $800 \mathrm{psig}$. 


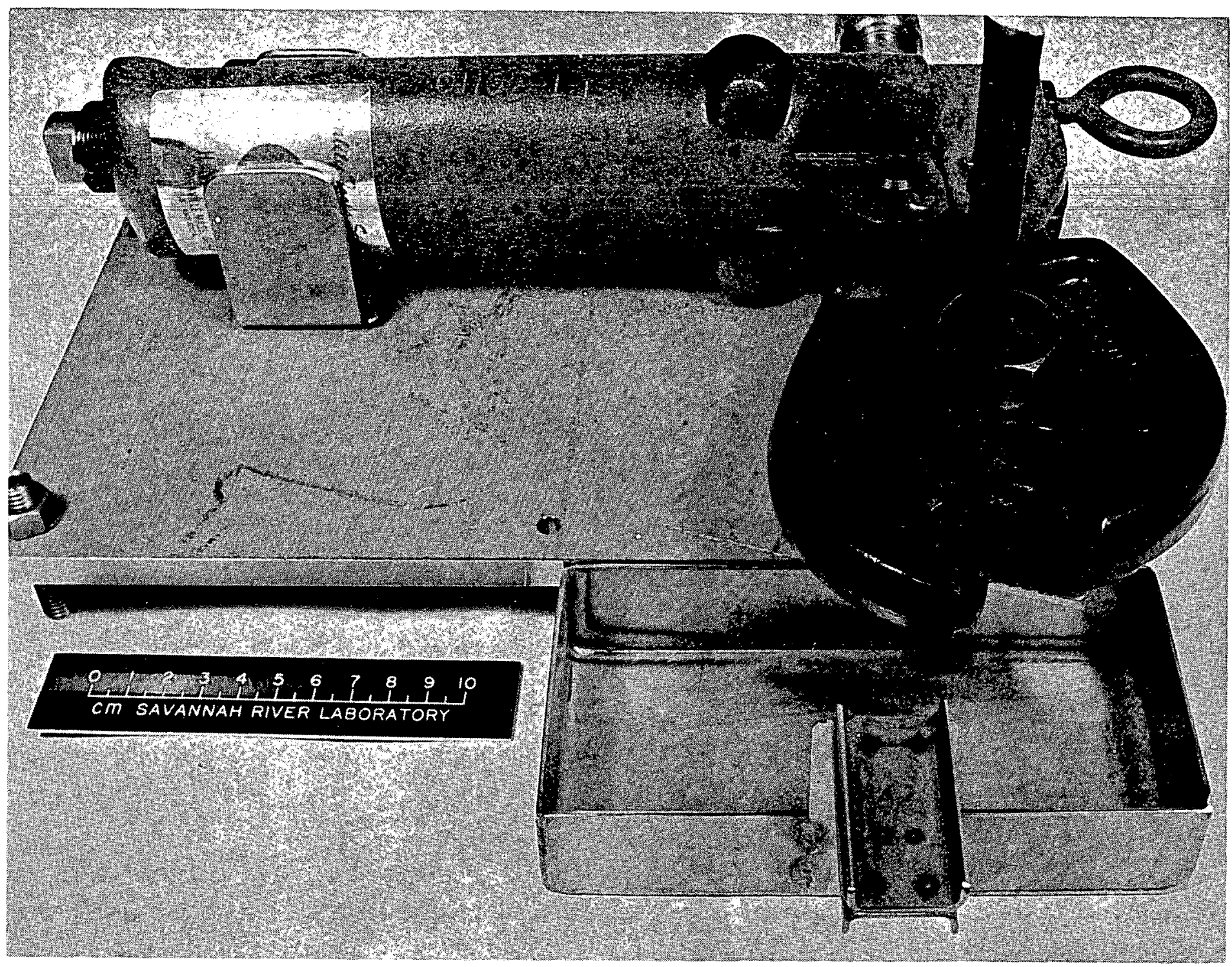

FIGURE 1A. Single-Pin Shear for Cutting LWR Fuel Rods 


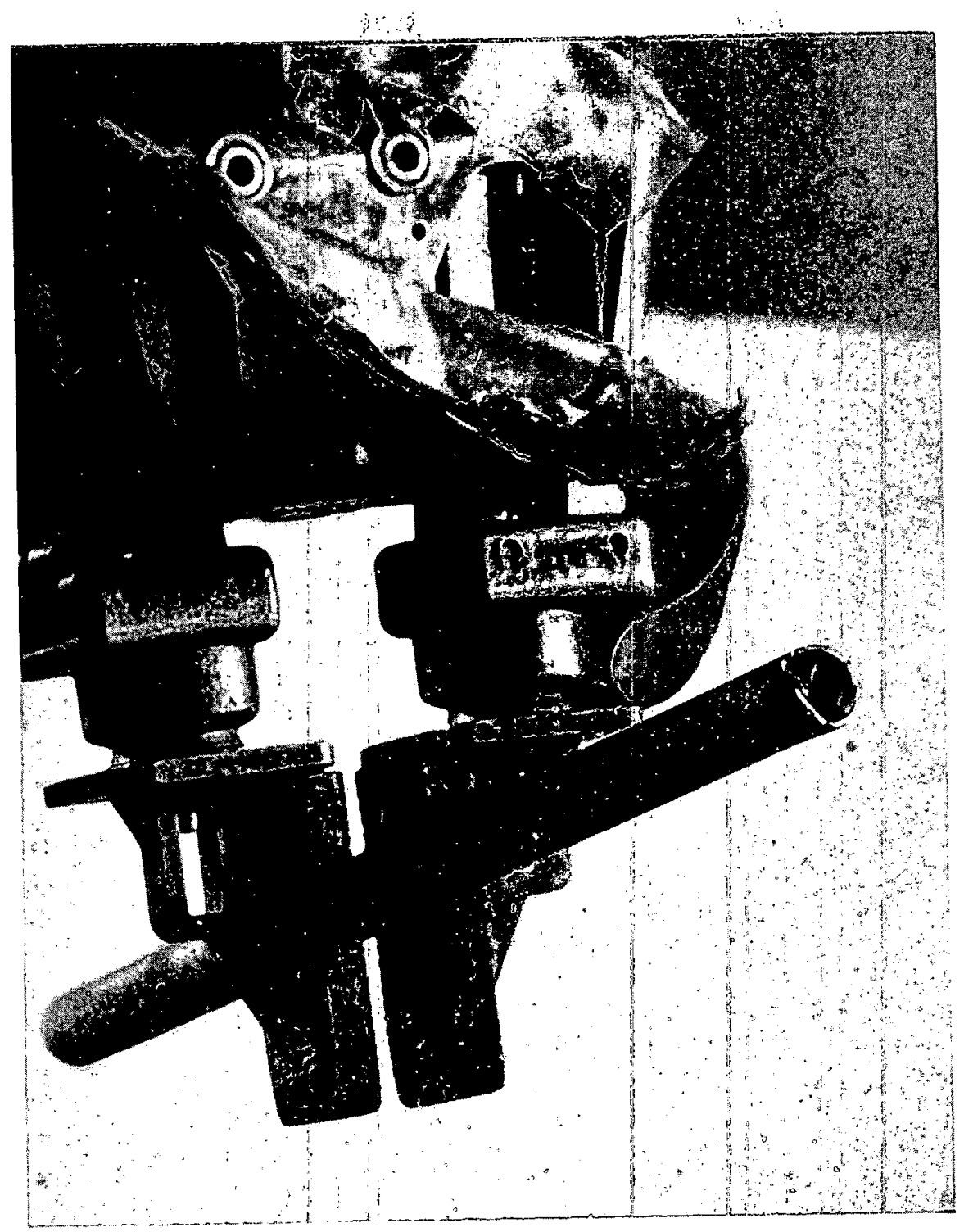

FIGURE 2A. Sheared Fuel Rod from H. B. Robinson-2 Reactor 


\section{APPENDIX B: STATIC BED VOLOXIDATION: PROCEDURES AND RESULTS}

Several voloxidation tests were made without agitation of the fuel fragments and/or clad fuel pieces in a laboratory muffle furnace. These tests are described below. All other tests were in the metal voloxidizer equipment, generally at $490^{\circ} \mathrm{C}$ in about $20 \%$ oxygen atmosphere. In those tests, the fuel was tumbled with a rotary agitator at $3.5 \mathrm{rpm}$.

Unirradiated Fuel. Ten one-inch pieces from a Zircaloy-4 clad, depleted $\mathrm{UO}_{2}$ fuel rod purchased from Combustion Engineering, Inc., were voloxidized in a static bed (no agitation) for three hours at $500^{\circ} \mathrm{C}$ in air in a laboratory muffle furnace. The oxide fuel separated from the cladding as a $\mathrm{U}_{3} \mathrm{O}_{8}$ powder which retained the original pellet shape as it was forced away from the ends of the cladding (Figure $1 \mathrm{~B}$ ). The voloxidized fuel reduced easily to a fine powder by stirring with a spatula. Sieve analysis showed that more than $80 \%$ of the particles were less than $44 \mu \mathrm{m}(-325$ mesh U.S. Standard). Coulter counter analysis showed the average particle size was about $5 \mu \mathrm{m}$.

After cooling, some of the fuel in the center of the clad pieces was not powdered. The powdered fuel and a sample scraped from the surface of the residual fuel were identified as $\mathrm{U}_{3} \mathrm{O}_{8}$ by $x$-ray diffaction. Further voloxidation resulted in continued powdering of the fuel, indicating possible additional oxidation (Table 1B). However, all of the fuel was not powdered after three heating cycles. Six of the clad pieces contained $<\mathrm{l} g$ of fuel (i.e., no solid pellets contained within the cladding), but four pieces contained 10 to $15 \mathrm{~g}$ of fuel as a solid pellet. X-ray diffraction data identified the core of the residual fuel pellets as $\mathrm{UO}_{2}$.

A thermocouple embedded in the $\mathrm{UO}_{2}$ fuel inside the cladding before voloxidation showed no significant temperature increase due to the exothermic oxide conversion reaction. Thus, the cladding was not heated above the oven temperature of $500^{\circ} \mathrm{C}$.

Irradiated Fuel. Unclad $\mathrm{UO}_{2}$ fuel fragments $(199.3 \mathrm{~g}$ for Test 5) from the H. B. Robinson-2 reactor (about 28,000 MWD/MTHM burnup) were heated in a static bed at $520^{\circ} \mathrm{C}$ in air for three hours with a muffle furnace. The furnace door was fitted with a doubly-insulated quartz window to permit observation of the fuel during voloxidation. The fuel fragments began disintegrating to a fine powder near $430^{\circ} \mathrm{C}$ during the heating cycle. The fragments appeared to powder at their surfaces initially, rather than 


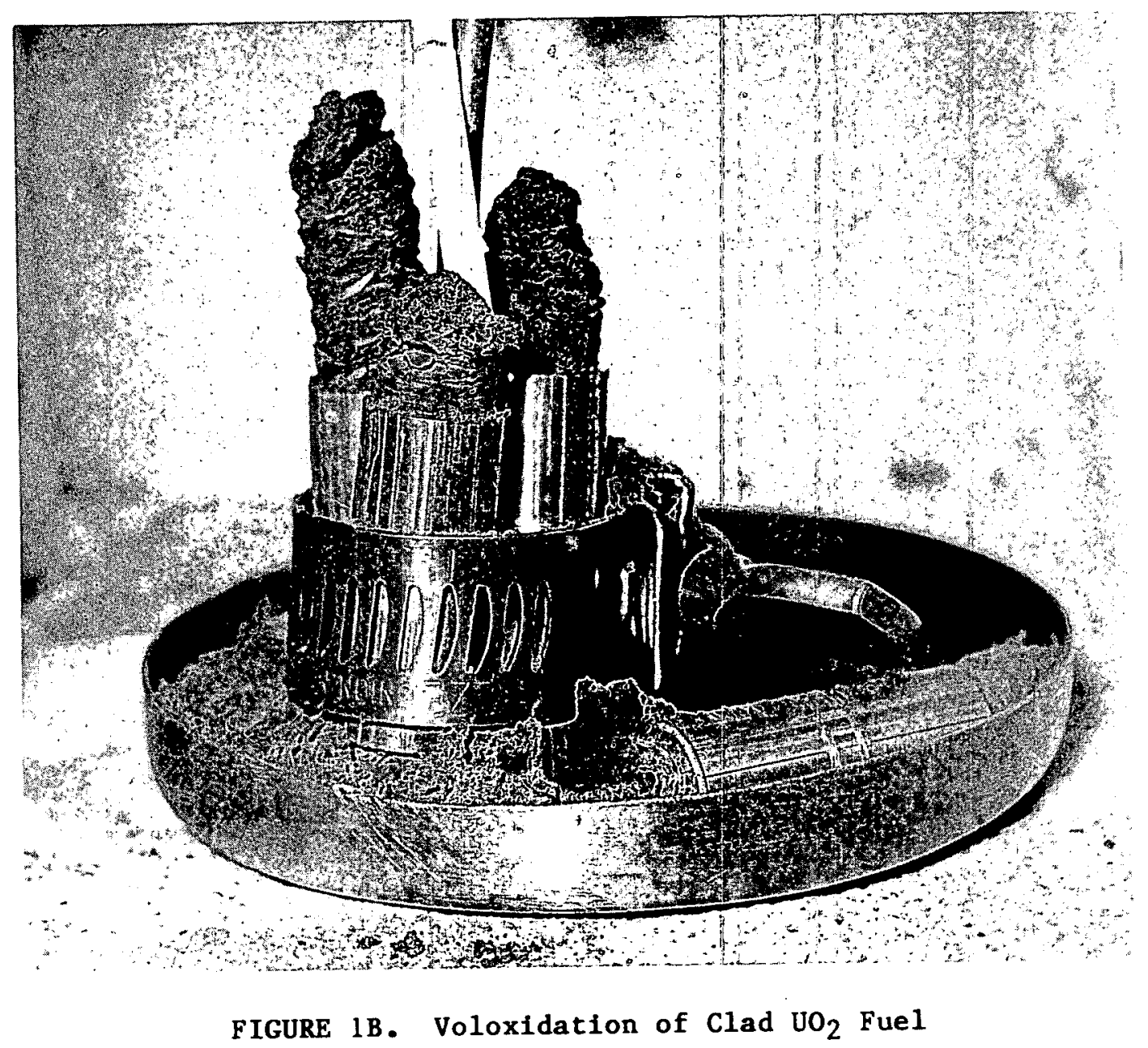


TABLE 1B

Voloxidation Test of Unirradiated $\mathrm{Clad}^{-\mathrm{UO}_{2}}$ Fuel

\begin{tabular}{|c|c|c|c|c|}
\hline \multirow[b]{2}{*}{$\begin{array}{l}\text { Heating } \\
\text { Cycle } \mathrm{e}^{\mathrm{a}} \\
\end{array}$} & \multicolumn{4}{|l|}{ Uranium } \\
\hline & $\begin{array}{l}\text { Oxidized } \\
\text { per } \\
\text { Cycle, } \mathrm{g}^{\mathrm{b}}\end{array}$ & $\begin{array}{l}\text { Total } \\
\text { Oxidized, g }\end{array}$ & $\begin{array}{l}\text { Not } \\
\text { Oxidized, g }\end{array}$ & $\begin{array}{l}\text { Not Powdered } \\
\text { per Cycle, \%c }\end{array}$ \\
\hline Start & - & - & 172.3 & - \\
\hline 1st & 90.5 & 90.5 & 81.8 & 47.5 \\
\hline 2nd & 31.4 & 121.9 & 50.4 & 61.6 \\
\hline $3 r d$ & 2.5 & 124.4 & 47.9 & 95.0 \\
\hline
\end{tabular}

a. For each cycle, fuel pieces were heated in a static bed for three hours at $500^{\circ} \mathrm{C}$ in air atmosphere; $\mathrm{U}_{3} \mathrm{O}_{8}$ produced during each heating cycle removed before starting new cycle.

b. For reporting data, it is assumed that nonpowdered fuel has not been oxidized.

c. A total of about $28 \%$ of uranium was not powdered after three heating cycles. 
disintegrating completely in one step. Voloxidation was well controlled; no temperature excursion due to the exothermic oxidation reaction was recorded from a thermocouple embedded in the powder. The $\mathrm{UO}_{2}$ fuel was converted completely to a fine powder $\left(\mathrm{U}_{3} \mathrm{O}_{8}\right)$ by the voloxidation procedure. Sieve analysis showed that more than $95 \%$ of the powder was less than $44 \mu \mathrm{m}$ ( -325 mesh U. S. Standard).

In a second test, 12 Oconee-l clad $\mathrm{VO}_{2}$ fuel pieces were randomly selected from sheared one-inch pieces (for Test 7 ) and divided into three batches for voloxidation. A voloxidation cycle consisted of heating with a muffle furnace to $500^{\circ} \mathrm{C}$ for four hours in a static bed in air. The size of the equipment limited each cycle to only four clad fuel pieces. Each piece was marked and weighed prior to a voloxidation cycle. After cooling, all loose powdered fuel was separated from the clad pieces before they were reweighed. The clad pieces then were voloxidized in a second equivalent cycle and reweighed in the same manner. The weight of each piece during these procedures is listed in Table $2 \mathrm{~B}$.

About $60 \%$ of the total fuel was separated from the cladding as a fine powder $\left(\mathrm{U}_{3} \mathrm{O}_{8}\right)$ during the first voloxidation cycle. only $7 \%$ additional was separated in the second voloxidation cycle. Thus, further static-bed voloxidation cycles were not expected to separate the remaining fuel core (about $35 \%$ of total initial fuel core) from the cladding efficiently.

The total weight of oxide fuel recovered after each voloxidation cycle is summarized in Table 3B. The reported welghts for Batches 1 to 3 include both the weight of fuel separated from the cladding as a loose powder and the fuel core remaining within the cladding. A cladding weight of $3.6 \mathrm{~g}$ per inch was assumed in determining the welght of fuel remaining in each clad piece. The data clearly showed that the $\mathrm{UO}_{2}$ fuel was oxidized to $\mathrm{U}_{3} \mathrm{O}_{8}$ (on a weight basis) by one voloxidation cycle, even though all of the fuel core was not separated from the cladding. The fuel remaining within the cladding after the second voloxidation cycle was mechanically separated from the cladding with a spatula. The separated core was reduced easily to a finely divided $\mathrm{U}_{3} \mathrm{O}_{8}$ powder by stirring with the spatula, as would be expected for completely oxidized fuel.

A portion of Oconee-1 fuel fragments collected during shearing was voloxidized in a separate cycle to complete the required fuel charge for dissolution. These $\mathrm{UO}_{2}$ fragments were converted completely to a fine $\mathrm{U}_{3} \mathrm{O}_{8}$ powder by one voloxidation cycle ( $\mathrm{Table} 3 \mathrm{~B}$ ), as observed in the Robinson-2 fuel test.

No attempt was made to collect or analyze voloxidation offgas for either tritium or ruthenium during the static bed voloxidation tests with irradiated fuel. 
TABLE 2B

Welghts of Voloxidized Fuel Pleces from Oconee-l Reactor During Static-Bed Voloxidation Testa,b

We1ght, grams

\begin{tabular}{|c|c|c|c|c|}
\hline Piece & Batch & Initial & $\begin{array}{l}\text { After first } \\
\text { Cycle } \\
\end{array}$ & $\begin{array}{l}\text { After Second } \\
\text { Cycle }\end{array}$ \\
\hline 1 & 1 & 16.9 & 11.6 & 8.6 \\
\hline 2 & 1 & 15.4 & 10.0 & 8.8 \\
\hline 3 & 1 & 14.3 & $3.7 \mathrm{e}$ & $3.7 \mathrm{e}$ \\
\hline 4 & 1 & 10.1 & $3.6^{\mathrm{e}}$ & $3.6 \mathrm{e}$ \\
\hline 5 & 2 & 14.8 & 9.7 & 9.2 \\
\hline 6 & 2 & 18.6 & 11.6 & 11.2 \\
\hline 7 & 2 & 17.5 & 11.0 & 10.9 \\
\hline 8 & 2 & 17.2 & 10.4 & 10.3 \\
\hline 9 & 3 & 19.5 & 9.5 & 7.5 \\
\hline 10 & 3 & 16.1 & 6.5 & 5.6 \\
\hline 11 & 3 & 16.6 & 9.8 & 9.0 \\
\hline 12 & 3 & 18.6 & 11.4 & 9.4 \\
\hline $\begin{array}{l}\text { Total (as } \\
\text { oxide fuel)f }\end{array}$ & - & 152.4 & 65.6 & 54.6 \\
\hline
\end{tabular}

a. At $500^{\circ} \mathrm{C}$ in $20 \%$ oxygen atmosphere.

b. All weights (except total) include $Z$ ircaloy-4 cladding (about $3.6 \mathrm{~g} / \mathrm{lnch}$ ); all loose powder was gently shaken from the pleces before welghing.

c. One-inch pleces picked randomly after shearing 17.5-inch rod segment.

d. Voloxidation ryrles are described in text.

e. These pieces contained no visible fuel core after first voloxidation cycle.

f. Total oxide fuel $\left(\mathrm{UO}_{2}\right.$ or $\left.\mathrm{U}_{3} \mathrm{O}_{8}\right)$ contained in cladding. 
TABLE 38

Welght of Uranium Oxide During Stat1c-Bed

Voloxidation of Oconee-1 Fuela,b

\section{Weight, grams}

\begin{tabular}{|c|c|c|c|c|c|}
\hline Batch & Inftial & $\begin{array}{l}\text { After First } \\
\text { Cycle }\end{array}$ & $\begin{array}{l}\text { After Second } \\
\text { Cycle }\end{array}$ & Calculated & Y1eld, \% \\
\hline$i$ & 42.3 & 43.6 & 43.6 & 43.9 & 99.2 \\
\hline 2 & 53.7 & 56.0 & 56.0 & 55.8 & 100.4 \\
\hline 3 & 56.4 & 58.7 & 58.7 & 58.6 & 100.2 \\
\hline Subtotale & 152.4 & 158.3 & 158.3 & 158.3 & 100.0 \\
\hline $4 f$ & 36.0 & 37.3 & - & 37.4 & 99.7 \\
\hline Total & 188.4 & 195.6 & 195.6 & 195.7 & 99.9 \\
\hline
\end{tabular}

a. At $500^{\circ} \mathrm{C}$ in $20 \%$ oxygen atmosphere.

b. Weight reported is that of loose powdered fuel plus fuel contalned in clad pieces; welght of $\mathrm{Z}$ ircaloy -4 cladding excluded.

c. As spectfied in Table $2 B$.

d. Assumes all of initial fuel 1 s $\mathrm{UO}_{2}$; disregards fission product or plutonium content of fuel.

e. Total fuel from clad pleces.

f. Fuel fragments collected during shearing; heated for one cycle only. 


\section{APPENDIX C: DISSOLUTION TESTS WITH POINT BEACH REACTOR FUEL}

Fourteen dissolution tests (Test 20 to 33) with Point Beach Reactor fuel were completed subsequent to the tests with Robinson, Oconee, and Saxton fuels described in this report. No problems which alter the conclusions made in the report were encountered in dissolving the Point Beach fuel. For voloxidized fuel, test results which support those conclusions include: low tritium content in solution, reduced ${ }^{106} \mathrm{Ru}$ concentration in solution, increased insoluble fission product residue weight, and increased weight of insoluble plutonium in the residue. Weight of insoluble plutonium depended inversely on final dissolver acid concentration (as high as $8 \%$ of total plutonium at about $1 \mathrm{M} \mathrm{HNO}_{3}$ ). Insoluble plutonium was leached to acceptable losses $(<0.02 \%)$ by fresh $10 \mathrm{M}$ $\mathrm{HNO}_{3}$.

Dissolution data for the Point Beach fuel are summarized in Tables 1C to 7C. These tables are extensions of tables prepared for Robinson, Oconee, and Saxton fuel in this report. Table 1C extends Table 1; Table 2C extends Tables 2, 4, and 6; Table 3C extends Tables 3, 5, and 7; Table 4C extends Tables 8, 9, and 10; Table 5C extends Tables 11, 12, and 13; Table 6C extends Table 15; and Table 7C extends Table 17. Figure IC summarizes typical dissolution rate data determined from $85 \mathrm{Kr}$ evolution data.

Fuel Description. Zircaloy-clad $\mathrm{UO}_{2}$ fuel rods were irradiated In Point Beach Reactor assembly D-040 and discharged at the end of Cycle $3(11 / 16 / 75)$. The initial enrichment was $3.05 \% 235 \mathrm{U}$. Fuel burnup was reported to be 28,000 to $29,000 \mathrm{MWD} / \mathrm{MTHM}_{0}$. Segments from Rod 014 containing $\mathrm{UO}_{2}$ fuel pellets fabricated to $96 \%$ theoretical density (TD) were used in Tests 20 to 30 . Most of the active fuel column length from Rod 014 was used in that series of tests. Segments from Rod 045 containing $\mathrm{UO}_{2}$ fuel pellets fabricated to $94 \%$ TD were used in Tests 31 to 33 . Table $2 \mathrm{C}$ specifies positions of each test segment in relation to total fuel column length of 145 inches for each rod.

Experimental Conditions. Each of the dissolution tests with Point Beach fuel was made in the voloxidizer/dissolver equipment. The fuel was dissolved by the batch process described in the report. Dissolution conditions are summarized in Table 2C. Solutions, insoluble residue, and off-gas were treated in the same manner described for Robinson, Oconee, and Saxton fuels.

Dissolution Rate. The only significant effect due to fuel density ( $96 \%$ TD vs $94 \%$ TD) was a slower dissolution rate 
TABLE IC

Measured Isotoplc Compositions for Point Beach Fuel

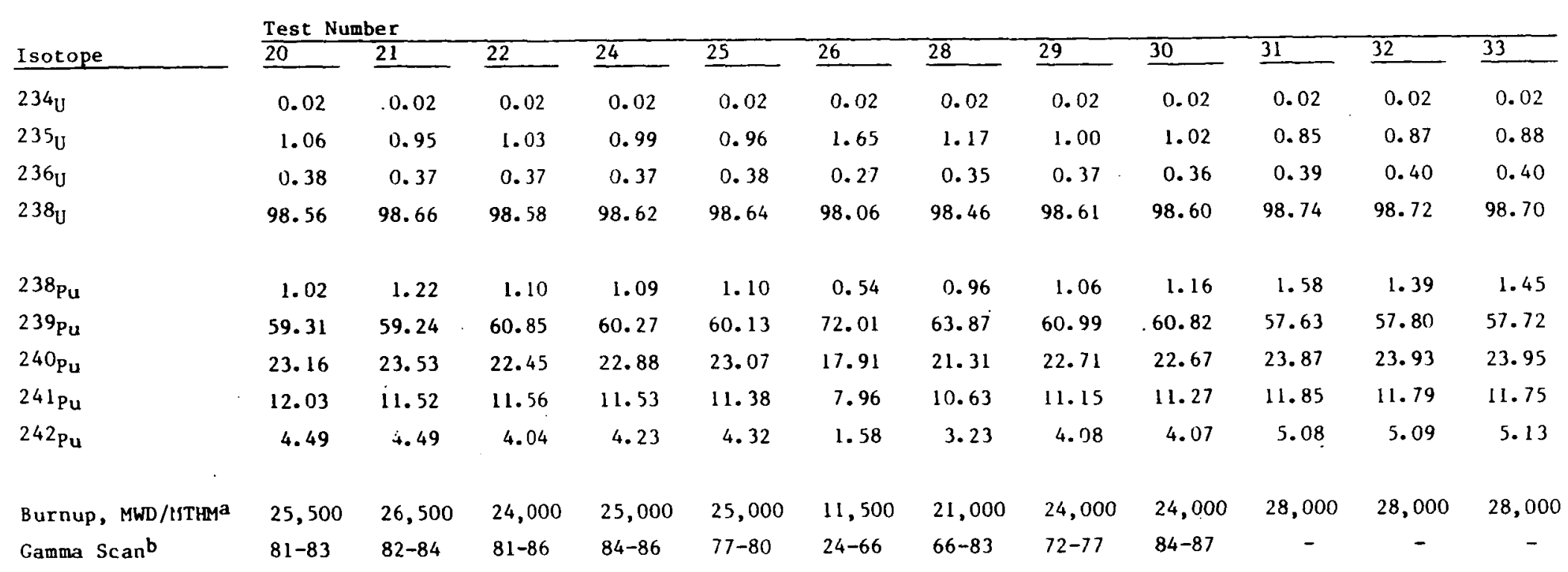

a. Estimated fuel burnup from GLASS code calculations.

b. Relative signal magnitude (based on 100 full-scale) for each rod segment, from gross gamma scan along the entire length of rod. For Tests 23 and 27 , signal magnitudes were 80 to 82 and 17 to 57 , respectively. 
TABLE 2C

Dissolution Conditions for Point Beach Puela

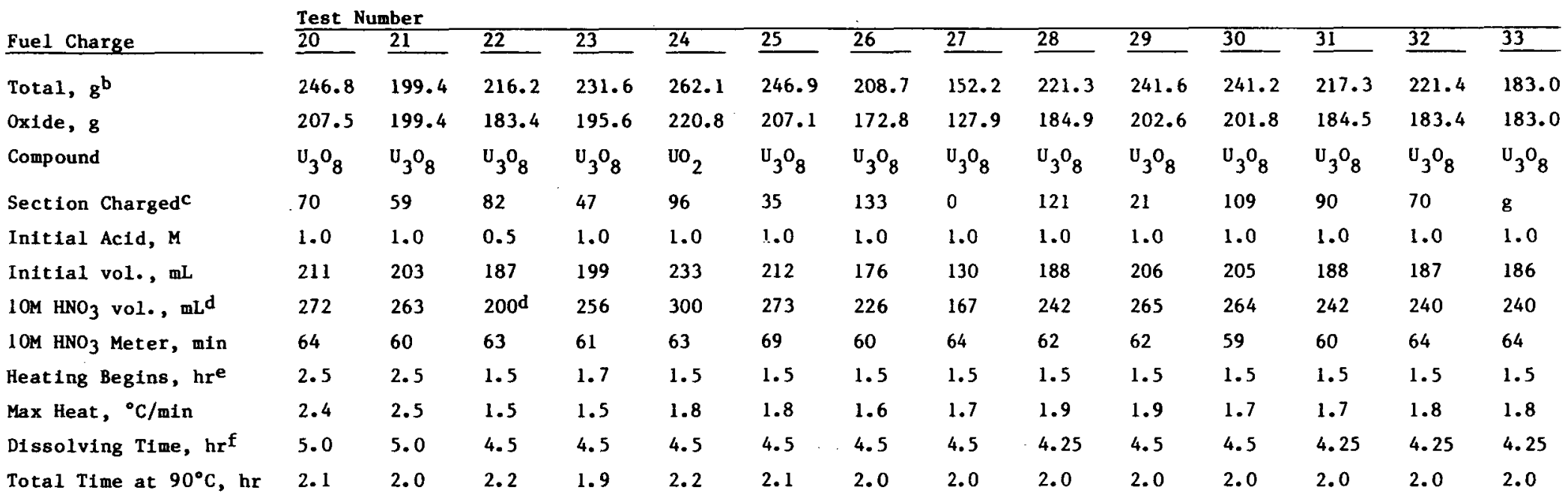

a. Tests 20 to 30 were made with $96 \%$ TD fuel; Tests 31 to 33 were made with $94 \%$ TD fuel.

b. Includes zircaloy-4 cladding weight, if different from oxide charge.

c. The position of the lower point of the rod section used for the test, measured in inches from the bottom of rod as placed in the reactor; each rod section was 11 to 12 inches long for $96 \%$ TD fuel and 15 to 20 inches long for $94 \%$ TD fue 1

d. Metered $9 \mathrm{M} \mathrm{HNO}_{3}$ in Test 22 .

e. These times are relative to the initial acid charge.

f. Total dissolving time, hours, relative to the initial acid charge.

g. Fuel fragments which were not used in Tests 31 and 32 were mixed prior to voloxidation and dissolution in this test. 
for nonvoloxidized high density fuel (Figure 1C vs Figure 3 in text for nonvoloxidized Oconee fuel). However, in all cases dissolution proceeded rapidly enough so that even the high density fuel was dissolved within four hours. In contrast, dissolution rates for voloxidized fuel $\left(\mathrm{U}_{3} \mathrm{O}_{8}\right)$ were observed to be independent of initial fuel density.

The dependence of dissolution rate on inftial acid concentration charged to the dissolver was equivalent to that observed for Robinson, Oconee, and Saxton fuels. The shape of the $85 \mathrm{Kr}$ evolution curve for the nonvoloxidized fuel (Test 24) suggests that a significant fraction of the high density fuel (about 15 to 20\%) was difficult to dissolve, even at high solution temperatures. No other tests with nonvoloxidized high density fuel were made to check this dissolution behavior.

For test 21 , extending the period before initial heating of the fuel solution from 1.5 to 2.5 hours resulted in dissolution of about $20 \%$ more of the total voloxidized fuel charge over that period. In this case, the dissolution rate for extended periods of time at ambient temperature appears to decrease slowly, so that quite long periods ( $>4$ hours) would be required to ensure complete fuel dissolution at low temperatures. Since dissolution rates during heating of the fuel solution are well-controlled, no incentive for increasing the time period for initial heating of the solution beyond 1.5 hours is demonstrated.

Characterization of Dissolver Solution. Final dissolver solution analyses (Table $3 \mathrm{C}$ ) were consistent with complete dissolution of the uranium fuel. Actinide and fission product concentrations in the dissolver vessel rinses and the $10 \mathrm{M} \mathrm{HNO}_{3}$ leach of the rinsed cladding were acceptably low, demonstrating that only slight amounts of fuel remalned undissolved.

Measured gamma-emitting fission product concentrations in the dissolver solution (Table 4C) are consistent with a lower soluble $106_{\mathrm{Ru}}$ concentration from voloxidized fuels. Concentrations of $137 \mathrm{Cs}$ and $144 \mathrm{Ce}$, which are completely soluble in the acid disso1vent, were equivalent for voloxidized and nonvoloxidized fuels, as expected. The average $137 \mathrm{Cs}$ concentration measured for each test segment generally followed the estimated fuel burnup (Table 1C).

Characterization of Insoluble Residue. The weight of inso1uble residue recovered from voloxidized fuel (Table 6C) was about $2 \mathrm{X}$ greater than the weight recovered from nonvoloxidized fuel, as expected. The major elemental constituents of the residues, as determined by spark-source mass spectrometry, were noble metal fission products, as observed for Robinson and Oconee fuels (Table 16). As expected, the weight of insoluble residue 


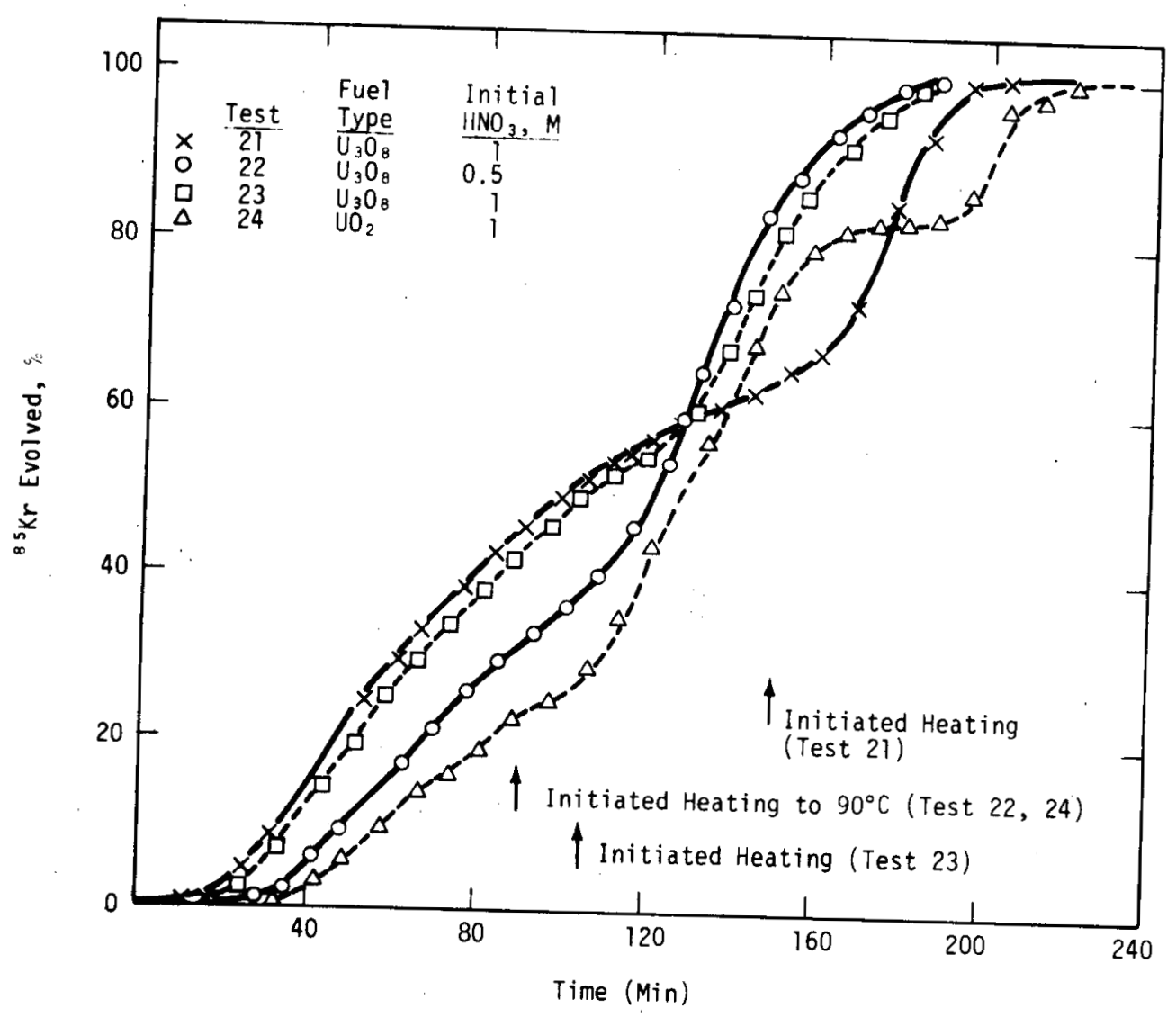

FIGURE 1C. Dissolution Rates of Irradiated Point Beach Fuel. 
TABLE $3 C$

Dissolver Solution Parameters for Point Beach Fuel

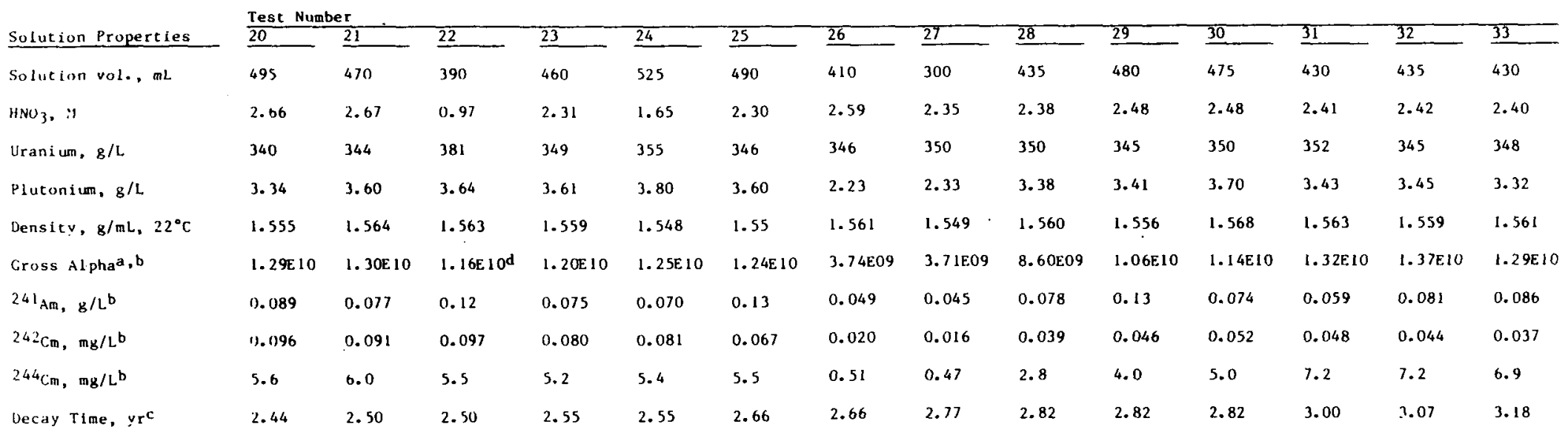

a. Dis/(min) (gU).

b. Encurrected for alpha decay (a1l concentrations at analysis date).

c. Fuel discharge date: $11 / 16 / 75$ (all tests).

d. B.6\% of plutonium not dissolved in this test; corrected gross alpha is $1.29 E 10$

when plutunium leached frum residue is included. 
TABLE 4C

Gamma-Emitting Fission Products in Dissolved Point Beach Fuel Solutions, a,b dis/(min)(gD)

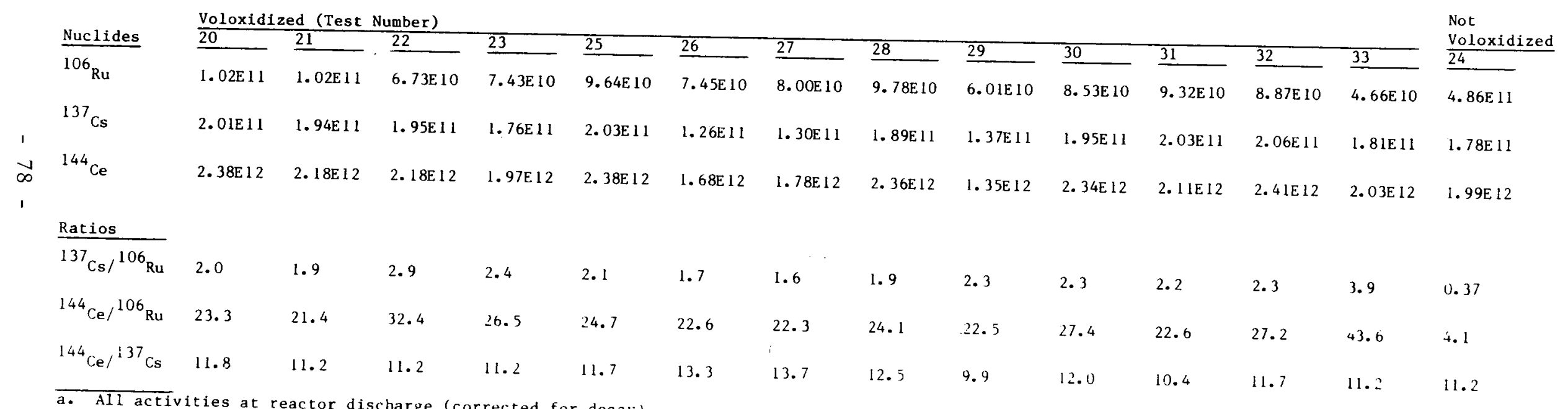

\footnotetext{
b. ${ }^{106} \mathrm{Ru}(\mathrm{Rh}),{ }^{137} \mathrm{Cs}$, and ${ }^{144} \mathrm{Ce}$ were the only gamma-emitting nuclides in the solutions which could be measured with good precision.
} 
collected in each test generally followed the estlmated fuel burnup (Table 1C) for the specific test segment used.

The solution residues from voloxidized fuel contained measurable fractions of plutonium (Table 7C), as determined by $10 \mathrm{M} \mathrm{HNO}_{3}$ leaches of the residue. The actual amount of insoluble plutonium was dependent on final dissolver acid concentration (Figure 10). For Test 22 , as much as $8.6 \%$ of total plutonium was not dissolved at a final acid concentration of about $\mathrm{IM} \mathrm{HNO}_{3}$. However, insoluble plutonium was recovered easily by leaching with $10 \mathrm{M} \mathrm{HNO}_{3}$ in all tests. The uranium contalned in these leaches was very low, indicating complete dissolution of the uranium fuel during the initial dissolving cycle.

The only significant gamma-emitting fission product measured in the $10 \mathrm{M} \mathrm{HNO} \mathrm{H}_{3}$ leaches of the solution residue was $106 \mathrm{Ru}$. For Test 20 , the $106 \mathrm{Ru}$ concentration in the residue leaches represented about $5 \%$ of the total soluble $106_{\mathrm{Ru}}$ for voloxidized fuels, as observed for Robinson and Oconee fuels. The percentage of so1uble ${ }^{106} \mathrm{Ru}$ in the residue leaches was much higher in Test 22 (Table $7 \mathrm{C}$ ). This resulted from a lower ${ }^{106}$ Ru solublilty at the final dissolver acid concentration (about $1 \mathrm{M} \mathrm{HNO}_{3}$ ) in the initial dissolving cycle. However, the total soluble $106_{\mathrm{Ru}}$ was found to be equivalent for Test 20 and 22 (Table $7 \mathrm{C}$ ) after the $10 \mathrm{M} \mathrm{HNO}_{3}$ leach treatment.

Off-Gas Characterization. Nearly all of the tritium in spent fuel was evolved to the off-gas during voloxidation (Table 5C). In all tests, tritium concentrations in dissolver solutions were acceptably low, demonstrating favorable tritium decontamination factors as a result of voloxidation. As observed for Robinson, Oconee, and Saxton fuels, the major fraction of ${ }^{14} \mathrm{C}$ and $85 \mathrm{Kr}$ was evolved from the fuel during dissolving (Table 5C). For both radionuclides, a slightly higher fraction evolved during dissolution from the high density fuel ( $96 \% \mathrm{TD})$. Quantities of ${ }^{14} \mathrm{C}$ and $85_{\mathrm{Kr}}$ evolved to the off-gas from the low density Point Beach fuel (Tests 31 to 33 ) agreed well with data obtained for Robinson and Oconee fuels (Tables 11 and 12), which also were fabricated to 94\% TD. 
TABLE 5C

Distribution of Volatile Radionuclides from Processing of Irradiated Point Beach Fuela,f

$\frac{\text { Tritium, Ci/MTU }}{\text { Dissolver Solution }}$
Voloxidation of $f-G a s$
DFC

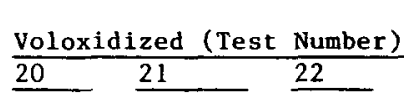

$\begin{array}{lllll}\frac{20}{0.136} & \frac{21}{0.0012} & 0.44 & 0.019 & 0.067\end{array}$

of

$\begin{array}{llllll}0.136 & 0.0012 & 0.44 & 0.019 & 0.067\end{array}$

$\begin{array}{lllll}154.4 & 132.9 & 117.3 & 128.5 & 99.5\end{array}$

$\begin{array}{lllll}1140 & 110,000 & 267 & 6600 & 1483\end{array}$

Carbon-14, Ci/MTUd

Dissolver of $f$-Gas

Voloxidation of $f$-Gas

$0.297 \quad 0.328$

$0.042 \quad 0.018$

0.313

$\begin{array}{lll}0.313 & 0.334 & 0.331\end{array}$

$\begin{array}{lll}0.036 & 0.028 & 0.034\end{array}$

$\begin{array}{lll}0.036 & 0.028 & 0.034 \\ 89.7 & 92.3 & 90.7\end{array}$

0.307

0.227

$\begin{array}{lll}0.598 & 0.336 & 0.461\end{array}$

$\begin{array}{lll}0.356 & 0.362 & 0.322\end{array}$

Not

$\%$ in Dissolver of $\mathbf{f}$-Gas

$87.6 \quad 94.8$

$89.0 \quad 92.3$

$\begin{array}{lll}90.3 & 86.4 & 90.0\end{array}$

$\begin{array}{lll}0.086 & 0.091 & 0.096\end{array}$

$\begin{array}{lll}80.6 & 79.8 & 77.0\end{array}$

0.225

1

\section{Krypton-85, Ci/MTU}

Dissolver of $f-G a s$

Voloxidation of $f$-Gas

$\begin{array}{ll}2562 & 2578 \\ 214.1 & 183.3 \\ 92.3 & 93.4\end{array}$

$\begin{array}{lllll}2257 & 2358 & 2277 & 1389 & 1936 \\ 185.1 & 176.7 & 175.9 & 104.0 & 80.8 \\ 92.4 & 93.0 & 92.8 & 93.0 & 96.0\end{array}$

$\begin{array}{ll}2174 & 1772 \\ 116.8 & 171.2 \\ 94.9 & 91.2\end{array}$

2631

$2706 \quad 283$

28312836

116.1

312.5

2831
368.5
88.5

348.8

2644

$\%$ in Dissolver of $f$-Gas

$<0.3<0.3$

$<0.3<0.3$

Dissolver Solution

$50.0 \quad 8.16$

$<0.3$

Dissolver of $f$-Gas

Voloxidation of $f$-Gas

$\%$ in Solution

$5.14 \quad 2.2$

$89.8 \quad 105.6 \quad 73.8$

NM NM NM

89.6

88.5

$89.0 \quad 100^{\mathrm{f}}$

a. See Table 11 for measured background levels determined from blank tests.

b. Tritium in dissolver off-gas was at, or below, measured background $(0.015 \mathrm{Ci} / \mathrm{MTU})$ in each test.

c. The decontamination factor (DF) was calculated as a ratio of the total tritium to the tritium measured in the dissolved fuel solution.

d. Carbon-14 in the dissolver. solution was at, or below, the measured background $(0.04 \mathrm{Ci} / \mathrm{MTU})$ in each test.

e. These values are questionable; they are based on one set of analyses and were not rechecked.

f. All percentages are based on total measured quantities; no assumption of losses prior to voloxidation or dissolution are included. 
TABLE 6C

Collected from Point Beach Fuel Dissolution Tests

Not
Voloxidized

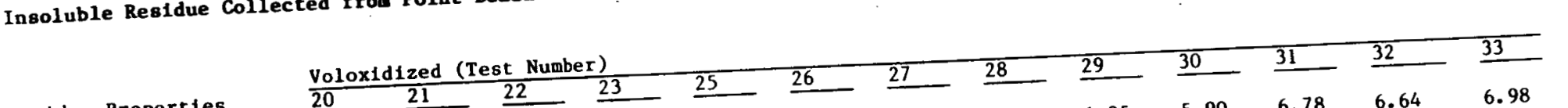

\section{Residue Properties}

Total Weight, kg/MTU

$\underline{20-} \underline{21} \frac{22}{5.80} 2.81$

$\begin{array}{lllllll}6.07 & 6.14 & 8.42 & 6.60 & 5.80 & 2.81 & 2.52\end{array}$

2.52

6.35

5.90

6.78

6.64

\% as Rinse Residue

tion for a discussion of residue terminology.

residue because of a broken centrifuge cone.

b. Incouplete recovery of rinse residue because of a broken cencr 
TABLE 7C

Acid Leaching of Insoluble Residue Collected from Point Beach Fuel

\begin{tabular}{|c|c|c|c|c|c|}
\hline Residue & $\frac{\text { Voloxid }}{20}$ & $\frac{\text { ed (Test }}{21}$ & $\frac{\text { Number) }}{22}$ & 23 & $\begin{array}{l}\text { Not } \\
\text { Voloxidized } \\
24\end{array}$ \\
\hline Total Weight, kg/MTU & 6.07 & 6.14 & 8.42 & 6.60 & 3.14 \\
\hline Solution Residue, $\mathbf{g}$ & 0.935 & 0.971 & 1.111 & 0.970 & 0.395 \\
\hline Rinse Residue, $g$ & 0.084 & 0.030 & 0.105 & 0.086 & 0.194 \\
\hline Flocculant Residue, $\mathrm{g}^{\mathrm{a}}$ & 0.012 & NDe & 0.039 & NDe & ND \\
\hline$\%$ as Rinse Residue & 8.1 & 3.0 & 8.6 & 8.1 & 33.0 \\
\hline$\%$ as Flocculant Residue & 1.2 & $\longrightarrow$ & 3.1 & - & 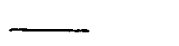 \\
\hline $\begin{array}{l}\text { Total Weight after } \\
10 \mathrm{M} \mathrm{HNO}_{3} \text { Leach, } \mathrm{kg} / \mathrm{MTU}\end{array}$ & 5.64 & - & 5.14 & $\longrightarrow$ & 2.12 \\
\hline $10 M \mathrm{HNO}_{3}$, Leach & & & & & \\
\hline W't "Dissulved & $6.4^{\mathrm{d}}$ & NDe & 28.4 & NDe & 32.4 \\
\hline int of Trotal: & & & & & \\
\hline Uranium & $0.004^{d}$ & ND & 0.013 & $\mathrm{ND}$ & $<0.001$ \\
\hline Plutonium & $0.30 \mathrm{~d}$ & ND & 8.62 & ND & 0.015 \\
\hline Soluble ${ }^{106} \mathrm{Ru}$ & 5.1 & ND & 43.6 & ND & 32.6 \\
\hline${ }^{137} \mathrm{Cs}$ & $<0.01$ & ND & 0.11 & ND & 0.05 \\
\hline $\begin{array}{l}\text { Total Soluble }{ }^{106_{R u}} \\
\text { dis/(min)(gU)c }\end{array}$ & $2.16 \mathrm{E} 10$ & $1.84 \mathrm{E} 10$ & $2.21 E 10$ & $1.29 \mathrm{E} 10$ & $1.25 \mathrm{E} 11$ \\
\hline
\end{tabular}

a. Residue collected from previously centrifuged dissolver solution after the addition of an organic flocculant (Prlmafloc $\mathrm{C}-3$ ).

b. Combined data from leaches of the solution and rinse residues.

c. Includes $106 \mathrm{Ru}$ in the dissolver and $10 \mathrm{M} \mathrm{HNO}_{3}$ leach solutions, uncorrected for decay.

d. For Test 20, concentrated $\mathrm{HCl}$ leaching of residue (after $1 \mathrm{OM} \mathrm{HNO}_{3}$ leach) dissolved $23 \%$ of residual solid. Uranium and plutonlum contalned in $\mathrm{HCl}$ leach were 0.003 and $0.02 \mathrm{wt} \%$, respectively, of the total concentrations.

e. Not determined. 